Florida International University FIU Digital Commons

$6-25-2018$

\title{
Inheriting Illegality: Race, Statelessness, and Dominico-Haitian Activism in the Dominican Republic
}

Jacqueline Lyon

Florida International University, jlyon016@fiu.edu

DOI: $10.25148 /$ etd.FIDC006870

Follow this and additional works at: https:// digitalcommons.fiu.edu/etd

Part of the Latin American Studies Commons, and the Social and Cultural Anthropology Commons

\section{Recommended Citation}

Lyon, Jacqueline, "Inheriting Illegality: Race, Statelessness, and Dominico-Haitian Activism in the Dominican Republic" (2018). FIU Electronic Theses and Dissertations. 3765.

https://digitalcommons.fiu.edu/etd/3765

This work is brought to you for free and open access by the University Graduate School at FIU Digital Commons. It has been accepted for inclusion in FIU Electronic Theses and Dissertations by an authorized administrator of FIU Digital Commons. For more information, please contact dcc@fiu.edu. 


\title{
FLORIDA INTERNATIONAL UNIVERSITY \\ Miami, Florida
}

\section{INHERITING ILLEGALITY: \\ RACE, STATELESSNESS, AND DOMINICO-HAITIAN ACTIVISM IN THE DOMINICAN REPUBLIC}

\author{
A dissertation submitted in partial fulfillment of \\ the requirements for the degree of \\ DOCTOR OF PHILOSOPHY \\ in \\ GLOBAL AND SOCIOCULTURAL STUDIES \\ by \\ Jacqueline Lyon
}


To: Dean John F. Stack, Jr.

Steven J. Green School of International and Public Affairs

This dissertation, written by Jacqueline Lyon, and Inheriting Illegality: Race, Statelessness, and Dominico-Haitian Activism in the Dominican Republic, having been approved in respect to style and intellectual content, is referred to you for judgment.

We have read this dissertation and recommend that it be approved.

Percy Hintzen

Okezi Otovo

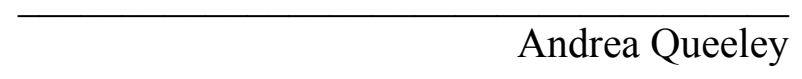

Jorge Duany, Major Professor

Date of Defense: June 25, 2018

The dissertation of Jacqueline Lyon is approved.

Dean John F. Stack, Jr.

Steven J. Green School of International and Public Affairs

Andrés G. Gil

Vice President for Research and Economic Development and

Dean of the University Graduate School

Florida International University, 2018 


\section{DEDICATION}

Dedicada al Movimiento Reconoci.do y al reconocimiento de todxs lxs Dominicanxs de ascendencia haitiana. 


\section{ACKNOWLEDGMENTS}

This project would not be possible without the support of Movimiento Reconoci.do. I have been forever changed by the stories, friendship, laughter, and tears we all shared together. Ana María, your strength in the face of adversity, your tenderness, drive, and friendship have been inspirations to me in the difficult process of completing this dissertation. Telemín, Rosa Iris, Elena, Juan Alberto, Cesar, Elmo, Epifania, all went above and beyond to guide me in this project and beyond. Thank you for your kindness, friendship, and support.

My fellow members of the Colectivo Isleño, Euclides, Hugo, Yesibon, and Regine, thank you for giving me an outlet to work on these issues outside the confines of the academy and allowing me to be an ally to the movement you are envisioning. To all of the staff at FLACSO, especially Franiel. Although I cannot name all of those who contributed to this project, it would not be possible without the many Dominicans who opened their homes and hearts to me.

To my family, both biological and chosen, you all inspire and push me in your own ways. To Christian, mi media naranja, who has always believed I could do anything. That means more to me than you will ever know. Without you by my side I would never have the surety to venture into these uncharted waters. To Yolanda and Jesús Mejía, who gave me a place to call home when I most needed it. I hope that I am as much the daughter you never had as much as you are the parents I never did. Also, to Derrick and Rachel, who have been a part of this journey from the very beginning. To my siblings: Paris, Brandon, 
Angelica, Arielle, Amara, Aidan, and Alyssa, you have all inspired me in your own way, even in your mistakes. A part of this belongs to all of you.

Miguel, we did it! Thanks for going to grad school so I could have someone to talk to. And to LT, you will be proud that this work takes seriously your suggestion that I listen. I will be happy to be half the professor and mentor you are.

I received support for this project from the Tinker Foundation, Phillips Exeter Academy Dissertation Year Fellowship, FIU's Dissertation Evidence Acquisition Award, and the Morris and Anita Broad Foundation. I extend my gratitude to my dissertation committee, Drs. Jorge Duany, Andrea Queeley, Percy Hintzen, and Okezi Otovo for your feedback on this project. 


\author{
ABSTRACT OF THE DISSERTATION \\ INHERITING ILLEGALITY: \\ RACE, STATELESSNESS, AND DOMINICO-HAITIAN ACTIVISM \\ IN THE DOMINICAN REPUBLIC
}

by

Jacqueline Lyon

Florida International University, 2018

Miami, Florida

Professor Jorge Duany, Major Professor

In 2013, the Dominican Republic's highest court ruled to revoke birthright citizenship for over 200,000 Dominicans of Haitian descent. Ruling TC 168-13 prompted dialogue about race and racism in the country, breaking the racial silence that accompanies mestizaje (racial mixture). Scholars viewed this ruling through the lens of "Black denial" whereby Dominicans' failure to adopt Black identities, despite being largely afrodescendant, fuels the racialization of Haitians as Black. Less evident in examinations of Dominican racial politics are anti-racist and anti-xenophobic organizing. Addressing the gap in scholarship on Dominican blackness, this dissertation project adopts an ethnographic approach to examine how Domicans of Haitian descent, most notably through Reconoci.do, a movement of denationalized youth, as well as the natural hair movement, engage with race. As one of the few well-articulated areas of Dominican society engaged with blackness, the natural hair movement provides a useful counterpoint for examining the intersections between blackness and Haitianess. In this work, I propose that natural hair 
has the potential to destabilize Haitian racialization yet, concurrently threatens to decouple the anti-racist movement from Dominico-Haitian struggles. These intersections illuminate the complex relationships within the heterogenous anti-racist movement.

Through a historically rooted examination of constructions of race and nation in immigration policies, censuses, and national identity cards, this dissertation asserts that immigration policies were designed to benefit the dominant sugarcane economy at the expense of migrants and thus state efforts in 2014 to address indocumentation continued earlier discriminatory patterns, disproportionately impacting the Haitian diaspora. These practices are best understood as spectacles (De Genova 2013) that produce migrant illegality and, in particular, an inherited illegality for Dominican-born children that violates their constitutional rights to citizenship. Furthermore, the state constructs the population as non-black while publicly undermining anti-racist organizing and this research finds that activists draw on transnational images of blackness to challenge national representations of a modern blackness. Identifying mestizaje and the color continuum as obstacles to organizing, many activists conceptualize blackness as hypodescent, whereby any African ancestry engenders a Black identity. I argue that, while essentialist, this strategy broadens identification with Dominico-Haitians. 


\section{TABLE OF CONTENTS}

\section{CHAPTER}

PAGE

1. RE-INTRODUCTION TO DOMINICAN BLACKNESS .......................

Blackness, Haitianess, and Dominicanidad: A Literature Review .............3

The Research Project.......................................................................... 14

A Reflexive Note........................................................................ 20

Overview of Chapters....................................................................24

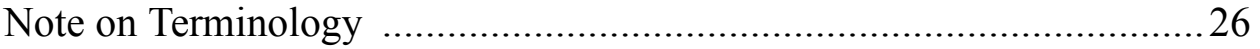

2. UNA SENTENCIA NO PUEDE BORRAR MI VIDA: DOCUMENTING THE

HAITIAN DIASPORA IN THE DOMINICAN REPUBLIC, 1920-2013.......28

Bringing the Braceros..................................................................... 31

Dispossession and Dominicanization at the Border.............................. 39

Era of Bilateral Accords ..................................................................... 44

Un país dentro de otro: Legal Exclusion and Rising Movements............50

The Role of the Junta Central Electoral ............................................55

Constitutional Change and La Sentencia..........................................5 59

Los Humanos Valemos +K Cualquier Ley..................................... 60

3. WITNESSING CITIZENSHIP: LEGAL PROCESSES OF

SUBJECTIFICATION ............................................... 64

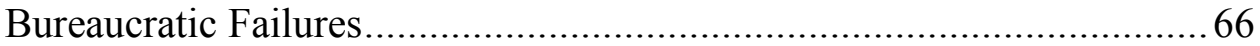

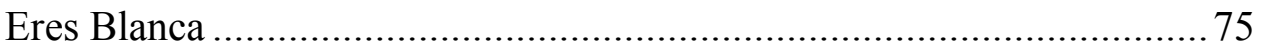

Deterritorialized Citizenship ......................................................... 81

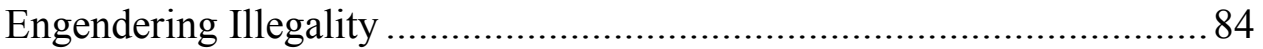

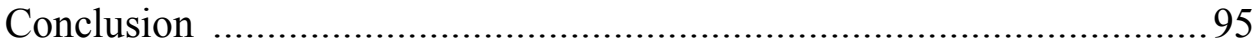

4. YO AMO MI PAJON: NATURAL HAIR AND THE NATIONAL BODY......100

Race, Beauty, and Hair .............................................................. 103

They Say Dominicans do the Best Hair: Straightening as Slavery......... 108

Men's Hair .................................................................................... 113

Institutionalizing Straight Hair .................................................... 116

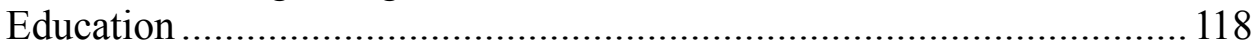

Roots of Resistance ............................................................... 122

The Dominican Natural Hair Movement............................................ 124

The Potential Politics of the Pajón ...................................................... 133

Conclusion: Splitting Hairs.......................................................... 140 
5. UN PAIS SIN ROSTRO: LOCATING RACE AND COLOR IN THE

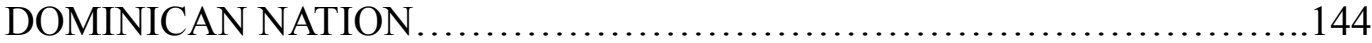

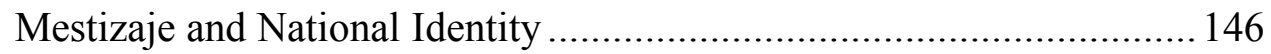

Mixed Race Scholarship ................................................................... 149

Race and Sovereignty after the Haitian Revolution............................... 152

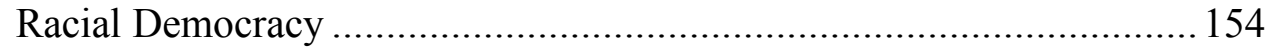

Race in the Dominican Census ........................................................ 156

Race, Color, and Cédula Categories................................................... 165

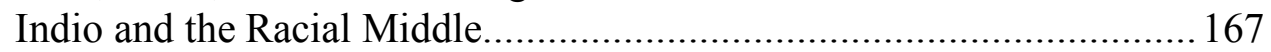

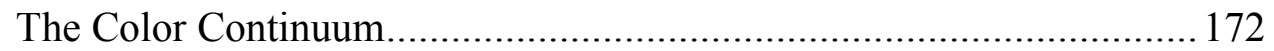

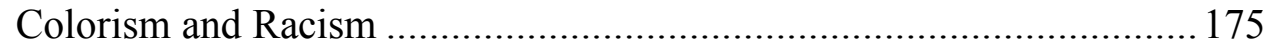

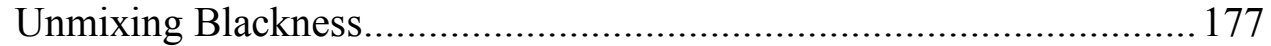

Transnational Blackness in Rap ...................................................... 184

Films and Funding........................................................................ 190

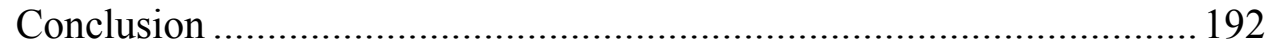

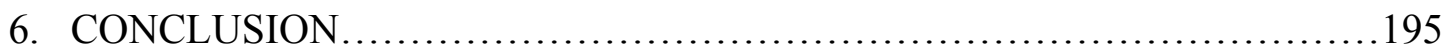

The Continued Fight for Citizenship................................................. 195

Citizenship and Race in the Dominican Republic and Beyond ............... 198

Areas for Future Research .................................................................208

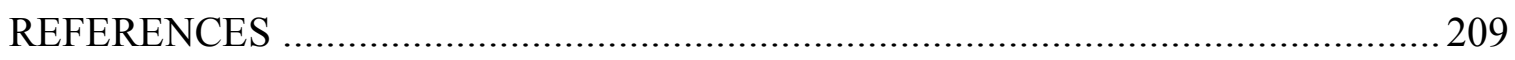

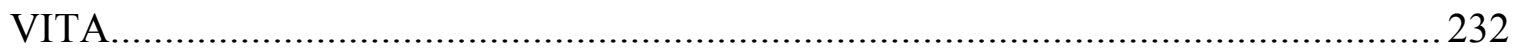




\section{LIST OF FIGURES}

FIGURE

PAGE

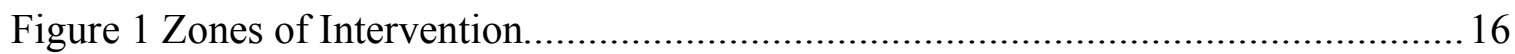

Figure 2 Protest sign in front of the JCE Santo Domingo .............................................28

Figure 3 Los humanos valemos mas que cualquier ley .................................................59

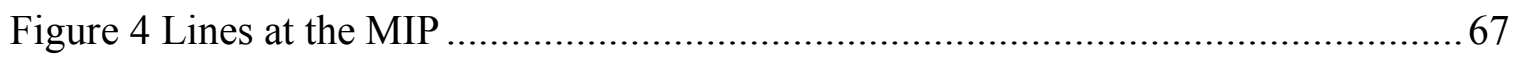

Figure 5 "Todo hijo de haitiaino es haitiano" ............................................................. 70

Figure 6 Alex Guerrero. Tu Afro No Cabe en la Foto ………………......................... 102

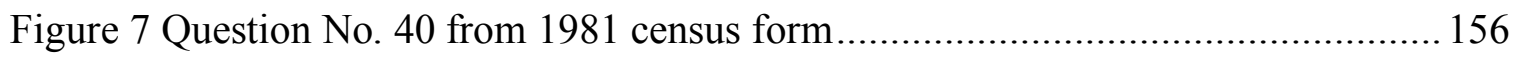

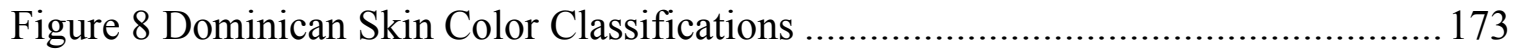




\section{LIST OF ABBREVIATIONS AND ACRONYMS}

$\begin{array}{ll}\text { AGN } & \text { Archivo General de la Nación } \\ \text { CCDH } & \text { Centro Cultural Dominico-Haitiano } \\ \text { CIDH } & \text { Corte Inter-Americana de Derechos Humanos } \\ \text { IACHR } & \text { Inter-American Court of Human Rights } \\ \text { JCE } & \text { Junta Central Electoral } \\ \text { MIP } & \text { Ministry of Interior and Police } \\ \text { MOSCHTHA } & \text { Movimiento de Trabajadores Domininico-Haitianos } \\ \text { MUDHA } & \text { Movimineto de Mujeres Dominico-Haitianas } \\ \text { OBMICA } & \text { Centro para la Observación Migratoria y el } \\ \text { ONE } & \text { Desarollo en el Caribe } \\ \text { PNRE } & \text { Oficina Nacional de Estadistica } \\ \text { SJM } & \text { Plan Nacional de Regularización de Extranjero } \\ & \text { Servicio Jesuita de Migrantes } \\ & \text { Tribunal Constitutional }\end{array}$




\section{CHAPTER 1}

\section{RE-INTRODUCTION TO DOMINICAN BLACKNESS}

[A]nti-haitianismo ideology has prevented Dominicans from recognizing their true racial identity and has perpetuated their racial "confusion" or denial.

—Ernesto Sagás, Race and Politics in the Dominican Republic, 2000, p. 125

One night in Santo Domingo, Dominican Republic, I finally made it to La Espiral, a partially open-air club popular with locals and tourists for its live, underground shows. I was there to see the band of one of my first friends on the island, La Gran Mawon, The Great Maroon. When I arrived, La Gran Mawon, had already begun to lull the crowd with its reggae set. El Caminante, "The Wanderer," as José liked to be called, had been an essential resource throughout my exploratory research on Dominico-Haitian struggles for nationality after a September 2013 ruling (168-13) by the Dominican Republic's highest court declared an estimated 200,000 people stateless. At odds with the prevailing discourse of universal anti-Haitian and anti-Black sentiment in the Dominican Republic, El Caminante, and others, drew on various representations in the global Black diaspora in their music, style, and self-presentation. Superseding the limits of the available nationalist discourse, the crowd that night shared in a space thoroughly imbued with representations of global blackness. Afros and dreadlocks swayed to music played by a band whose name combines Spanish and Haitian Kreyol in its reference to the island's runaway slave communities. When the group played Bob Marley's "Buffalo Soldier," the crowd sang along to the lyrics, "Stolen from Africa, Brought to America." It became clear throughout 
my time in the Dominican Republic that the America resonant with the crowd was not only the United States, but Latin America and the Caribbean too.

In the Dominican Republic, blackness is often expressed in nationalist discourse vis-à-vis Haiti. Founded in the historical memory of successive Haitian occupations during the colonial period, especially between 1822 and 1844, and perpetuated in the trope of invasive Haitian immigration, Haitians are often portrayed as the Dominican Republic's cultural and racial others. While Haitians are racialized as Black, the scene at La Espiral demonstrates how Dominicans draw on multiple meanings of blackness that cannot be captured through references to Haiti alone. Much of the literature that examines race has failed to consider Black cultural production beyond the Haitian question as it is expressed in music, film, and self-presentation, such as natural hair.

Given the context where Haitian exclusion, exemplified in ruling 168-13, is expressed through racialized difference, it is crucial to study the intersections between expressions of blackness and the politics of citizenship and belonging in the Dominican Republic. My dissertation examines the diverse engagements with blackness in the Dominican Republic with attention to the ways that its performatives and articulations exceed, challenge, and reinforce the ability of the Haitian metaphor to capture the range of Dominican entanglements with blackness. Particularly, this project situates Dominicans within the global Black diaspora. Based in Santo Domingo, the capital, largest city, and center of organizing against ruling TC $168-13,{ }^{1}$ which revoked the citizenship of the

\footnotetext{
${ }^{1}$ Ruling TC 168-13 was issued September 23, 2013 in response to Juliana Deguis's petition for the renewal of her documents by the Junta Central Electoral. The court's argument is founded on the 1929 constitution which excluded the children of those en transito ("in transit") from accessing birthright citizenship. The court argued that irregular migrants, regardless of their time in the country, are in transit.
} 
children of irregular migrants, this research examines the potential for re-signifying the national imaginary in ways that open spaces for blackness and the possibilities for the inclusion of Haitian immigrants and Dominicans of Haitian descent. This dissertation argues that the coproduction of race and nation vis-à-vis ideologies of mestizaje has engendered the exclusion of Dominicans of Haitian descent represented in the current citizenship crisis. Moreover, as anti-racist activists organize to challenge the mapping of blackness onto Haitianess, they risk the production of either exclusionary middle-class or broad, but potentially essentialist representations of blackness.

\section{Blackness, Haitianess, and Dominicanidad: A Literature Review}

In a June 2015 panel with activists, journalists, and artists responding to the crisis in citizenship, a representative from Acción Afrodominicana (Afro-Dominican Action) said, Cuando yo alejo del haitiano, yo alejo de mi propio yo, ("When I distance myself from Haitians, I create difference from my own self.") Although the speaker, Carmen, a self-identified Afro-Dominican is not of Haitian descent, her comments evidence and understanding that interlaces Haitianess with blackness. Her views are representative of the how Haitianess and blackness are frequently co-articulated in Dominican Republic. Although most Dominicans have African ancestry (Torres-Saillant 2010[1995]), in official discourse and statistics, most are constructed as indios. While literally meaning "Indian," in practice, indio refers to Dominicans' mixed indigenous, European, and African ancestries. Ideologies of mestizaje (racial mixture) in the Dominican Republic and elsewhere have been critiqued by social movements and academics who have characterized them for being "all-inclusive ideology of exclusion" (Stutzman 1981). A major issue is that 
the contributions of the "third root," Africa, are often marginalized in nationalist representations, exacerbated by the historical intertwining of mestizaje with eugenicist science in the early to mid- $20^{\text {th }}$ century. In this vein, racial mixture has been articulated as a racial improvement paradigm whereby blackness would be washed out through selective reproduction—whitening, or blanqueamiento. Racial mixture in Latin America provides what Carl Degler refers to as the "mulatto escape hatch" (1986[1971]), whereby an appeal to racial mixture removes one from the Black category, and some have argued that Dominicans utilized an "indio escape hatch" (see Sagás 2000; Tavernier 2008). Where most Dominicans construct themselves as indios, blackness is almost exclusively utilized in reference to the country's Haitian minority.

Silvio Torres-Saillant, in Introduction to Dominican Blackness (2010[1995]), laments the failure of scholars in anthropology, Black cultural studies, and Latino studies to center the Dominican Republic as a site of blackness. Several collections that explore blackness in the Dominican Republic published in the 1990s elide Dominican engagements with blackness, despite its status as the "cradle of blackness in the Americas" (TorresSaillant 2010[1995], 110). Torres-Sailliant's call was answered by a growing interest Dominican racial studies that has accompanied the increase in Dominican immigrants to the United States. Accordingly, many studies examine how Dominican arrivals and the second generation become Black vis-à-vis their encounters with a US racial system that invalidates the mixed-race identities Dominican migrants bring from their homelands. Studies in Providence, R.I. (Bailey 2002; Itzigsohn and Dore-Cabral 2000; Itzigsohn 2009), Boston (Levitt 2001), Washington, D.C. (Candelario 2007), and New York City (Candelario 2007; Duany 2008[1994]; Hoffnung-Garskof 2008; Roth 2012) illuminate the 
ways Dominicans negotiate their racialization as Black. This racialization not only causes a "cognitive shift" (Duany 1998) in the ways individual Dominican emigrants think about race but has arguably resulted in the acceptance of blackness on the island, attributed to "the behavior of returning migrants who go back to their communities transformed into new agents of modernity, capitalism, and racial emancipation" (Moya Pons 1981, 32-33). More broadly, these individual circulations contribute to a "transnational social field" (Levitt and Schiller 2004) in which Dominican racial identity is simultaneously negotiated by migrants and non-migrants (Roth 2012). The present work examines how blackness and its articulations with Haitianess are shaped not only through patterns of migration between the US and the Dominican Republic, but through the transnational activist movements that help sustain the fight for Dominico-Haitian citizenship. Despite the strong connections scholars have made between blackness and Haitianess (Howard 2001; Sagás 2000; Tavernier 2008), none of these scholars addresses the implications these negotiations of blackness might have for transforming the relationship between the Dominican Republic and Haiti.

Scholars of race in the Dominican Republic highlight several historical moments when anti-Haitianism was consolidated in the Dominican Republic. Many locate the origin of the Dominican rejection of blackness in the events of the 1822-1844 Haitian unification of the island. In this narrative, Dominicans' successful war of independence from Haitinot from Spain — consolidated Dominican political and cultural opposition to their western neighbors. Haitians had organized themselves as a post-colonial black nation in opposition to their colonial oppressors, codified in the 1805 constitution, which proclaimed all Haitians no matter what their shade of skin, were to be considered "Black" (Nicholls 1996, 
35). Therefore, scholars of race in the Dominican Republic argue that it is no surprise that Dominicans fashioned themselves as patently non-black (Derby 2003; Ferguson 1992; Torres-Saillant and Hernández 1998; Sagás 2000). In contrast to the legal mandate of blackness institutionalized in Haiti, post-independence Dominican Republic "privileged European ancestry and Hispanic cultural norms" based on whiteness, Catholicism, and the Spanish language (Mayes 2014, 1-2). Arguably, this Dominican criollo identity began to develop earlier in the colonial period due to the colony's poverty and the less-profitable plantation economy (Derby 1994; 2003; Sagás and Inoa 2003).

However, Samuel Martínez (2003), responding to Michele Wucker's book Why the Cocks Fight (1999), argues that scholars have over-emphasized anti-Haitian ideology by failing to consider "instances of cooperation and evidence of converging interests among Haitian and Dominican people and their governments" (2003, 81). Martínez admits that Dominicans construct themselves as fundamentally distinct from Haitians; however, he emphasizes that close daily contact between Haitians and Dominicans greatly reduces negative sentiments (Martínez 2003, 89). Similar studies of Haitians and Dominicans who live along the island's border confirm the existence of shared social and cultural spaces between these communities (Derby 1994; 2003; Paulino 2016; Turits 2003). These findings suggest that anti-Haitianism is evident in national ideology but is not universally shared. Martínez and others (Franco 2003; Paulino 2016; Sagás 2000) point to the need to examine how and when anti-Haitian discourse and politics emerge. In this vein, most scholars of Dominican-Haitian relations examine the promotion of anti-Haitian ideology and practices after the Haitian Revolution, during the US occupation (1916-1924) of the island, and the subsequent dictatorship of Rafael Trujillo (1930-1960). 
The first of these key historical events shaping contemporary Dominican-Haitian relations is the 1791 Haitian Revolution. The revolution reverberated throughout the region, both inspiring rebellion throughout the colonial world and the fear of vanishing empires (Geggus 2003). Attesting to the ideological and political challenges that Haiti posed Western powers as the first independent black republic, in the aftermath of the revolution, the US and other Western powers went to great lengths to prevent further uprisings. Intervention was justified through discourses of racial and sexual difference. For example, President Ulises Heureaux, President of the Dominican Republic (1886-1899), of Haitian and West Indian parentage, was described by one US state official as having the "weaknesses 'of the savage—-his domination by his sexual passions, which were never satiated, and his lust for blood"” (Torres-Saillant and Hernández 1998, 23).

In this context, leaders in the Dominican Republic "struggled with the problem of black political leadership in a historical moment saturated with antiblack racism and fear of black political power" (Mayes 2014, 7). Ginetta Candelario (2007) traces how the discourses of difference shaped the nation-making process in the nascent Dominican state. Overlapping occupations of the western (1915-1934) and eastern (1916-1924) parts of the island of Hispaniola had a lasting impact on Dominican understandings of global racial hierarchies. In the accounts of US travelers and emissaries who sought justification for US colonization of the island, the Dominican Republic was racialized as white vis-à-vis Haitian blackness. Henceforth, "despite the country's African heritage, Dominican identity formations negotiated the fraught space between US-dominant notions of white supremacy that defined mixture as degeneration and the geopolitical positioning of Dominicans as 'los blancos de la tierra [whites of the land]' relative to Haitians" (Candelario 2007, 38). 
US authorities and foreign plantation owners encouraged the immigration of Haitian labor in the early $20^{\text {th }}$ century to meet the sugar industry's demand. Henceforth, Haitian workers became associated with the US occupation of the Dominican Republic. In practice, Haitians experienced harsher treatment from military officials during the extended occupation, "[t]he racial difference between Haitians and Dominicans, in which some Dominicans were perceived as racially mixed and thus closer to Europeans, justified, for many US authorities, continued military governance in Haiti and an end of occupation for the Dominican Republic" (Mayes 2014, 108). US policy in this case sharply differed from domestic US framings of race relations based on the principle of hypodescent, in which "one drop" of black blood categorized one as Black. Further, these examples place the Dominican Republic's national formation within the imperial context where adopting a mixed, rather than a black identity, had practical consequences for sovereignty.

Shortly after the end of US occupation, Rafael Trujillo seized power and attempted to exemplify the modern status of the Dominican nation which had been denied in the discourse of racial, sexual, and gendered inferiority that accompanied the country's annexation. Trained by the US Marines during their occupation of the Dominican Republic, Trujillo maintained a brutal dictatorship (1930-1961) which witnessed the institutionalization of violent and discriminatory practices against Haitians and AfroDominicans. Trujillo consolidated his power in large measure through racial discourse and violence. Of Haitian descent himself, Trujillo is famously known for powdering his face to appear lighter-skinned and encouraging the "Dominicanization" of the border region, paradoxically through European and Japanese migration (Horst and Asagiri 2010). These practices illustrate how "Dominican" was defined in contradistinction to Haitianess and 
blackness. The dictator also regulated cultural forms of blackness in the Dominican Republic such as vodou and the use of drums in merengue (Austerlitz 1997; Torres-Saillant 2010[1995], 21). This was part of a process whereby “[a]s frontier Dominicans became part of the nation as citizens, the Haitian community came to be labeled as foreigners threatening the body politic" (Derby 1994, 489).

As part of the process of "Dominicanization" in 1937, Trujillo orchestrated a brutal massacre of Haitians and Black Dominicans in the border region. Attesting to the uncertainty with which Dominicans identify Haitian racial difference, the slaughter is also known as the "Parsley Massacre" for a test perpetrators devised to distinguish Haitians from Dominicans using the Spanish word perejil, which Kreyol speakers often pronounce as pelehil (Ferreras 1981). ${ }^{2}$ An estimated 17,000 Haitians were killed in these events, which Trujillo attempted to frame as a popular uprising by ordering guards to wear civilian clothes and to use machetes in place of guns (Turits 2003). Until 2014, similar discourses of a Haitian invasion emanating from the pre-independence occupations and the border conflict continue to justify the "state of exception" (Agamben 2005) to suspend the legal protections previously granted to the children of undocumented migrants.

Further, Trujillo instituted the use of the indio category on the cédula de identidad nacional (national identity card). In the shadow of the massacre, "Dominicans of Haitian descent and black Dominicans ... were further disappeared by fiat under the state's classificatory system ... 'Indio' has come to be an affirmation of Dominican whiteness as well as non-blackness" (Candelario 2007, 19). To this day, the Junta Central Electoral

\footnotetext{
${ }^{2}$ Ramón Alberto, Ferreras, “¿Cómo fue la masacre haitiana?”, El Sol, 15 may 1981, Colección Bernardo Vega, Archivo General de la Nación No. 145-038, http://200.26.174.77/cbvnode/app.html\#/details.
} 
(Central Electoral Board or JCE) classifies the skin color of citizens as blanco (white), indio (Indian), amarillo (yellow), or negro (black). Although the agency does not report racial statistics, indio is disproportionately assigned despite the overwhelming population of blacks and mulattos (Simmons 2009; Torres-Saillant 1998).

In the Dominican Republic, blackness and foreignness became forged through these historical events. Colloquially, "Haitian" and "Black" are used interchangeably and calling someone either is considered an insult (Derby 1994). However, an increasing number of scholars have called to challenge work which, "[i]n addition to exacerbating the unjust treatment of Haitian migrants and their descendants ... exaggerated claims of irreconcilable differences between Haitians and Dominicans have negatively affected intellectual, cultural, and artistic exchange between the two countries" (Mayes et al. 2013, 27). This claim points to research which elides alternative engagements of blackness and Haitianess within the Dominican Republic. Torres-Saillant (1998) shows how the reproduction of the anti-Haitian narrative fails to explain the popular support for presidential candidate José Francisco Peña Gómez in the 1994 and 1996 elections, although the opposition emphasized his Haitian parentage to discredit his candidacy. Further, while this historical outline demonstrates the indisputable connections between Haitians and blackness in Dominican racial ideology, it elides other prominent references for blackness. For instance, Samaná, Puerto Plata, and San Pedro de Macorís were centers of Black 
migration from the United States and the West Indies that have been relatively unexamined. $^{3}$

Although mestizaje provides for the investment in a future whiteness for those who are unable to fully exercise its benefits, it also projects an image of all nationals as racially homogenous. Through the ideology of mestizaje, all nationals are considered racially mixed and to be Dominican is to be indio. Therefore, anyone who is not mixed is perceived as outside the boundaries of the Dominican nation, engendering the relationship between race and nation that intertwines anti-Black racism and xenophobia. This relationship is key to understanding how Dominico-Haitians are framed as ineligible for citizenship, and the production of their "illegality." The current citizenship crisis and the state's response frequently serve as a 'spectacle ... displacing 'illegality' from its point of production (in the law) to the proverbial 'scene of the crime,' which is of course also the scene of ostensible crime-fighting" (De Genova 2013, 1189). In the Dominican case, the scene of "crime-fighting" is less the border, than the internal registries, which authorities have

\footnotetext{
${ }^{3}$ Pedro R. Rivera $(2015,107)$ describes San Pedro de Macorís as the "blackest city in the country" due to the large Antillean migration to the city during the sugar boom the city experienced in the early $20^{\text {th }}$ century. Moreover, one of the first chapters of the United Negro Improvement Alliance was founded in San Pedro de Macorís, and later, Samaná (García Muñoz and Giovannetti 2003, 154). Harry Hoetink $(1962,3)$ noted "a quite numerous group of English-speaking Negroes, descendants of North American feedmen who came to this country nearly 140 years ago" living in the Samaná on the northern coast of the Dominican Republic. Although both Haitians and cocolos were classified en el polo más oscuro del continuo racial, el negro ... los haitianos ocupaban la posición más extrema. Las cualidades consideradas positivas de los cocolos-educación, destrezas, dedicación al trabajo, disciplina, religiosidad, dominio del inglés ... les ubicó en una posición distinta en la percepción de sectores de la sociedad dominicana (in the darkest pole of the racial continuum, black, Haitians occupied the most extreme position. Qualities considered positive of the cocolos-education, skills, dedication to work, discipline, religiosity, English dominance ... located them in a distinct position in the perception of sectors of Dominican society (García Muñoz and Giovannetti 2003, 170). Despite the racialization of cocolos, the majority of scholarship on blackness in the Dominican Republic has focused on the racialization of Haitians with almost no anthropological scholarship on the contemporary experiences of Dominican cocolos.
} 
argued need to be cleaned of fraud due to the "deceptive" practices through which Haitians have historically accessed citizenship.

A group of scholars known as the Transnational Hispaniola Working Group has produced scholarship aimed at offering more complex renderings of Dominican-Haitian relations and Dominican racial formation. These works begin to address the implicit bias of the existing scholarship on Dominican blackness, arguing that "even when investigators find a recognizable (to them) embrace of African origins and black identity, there is nevertheless a strange inability to let go of narratives emphasizing Dominican self-hatred, negrophobia, and anti-Haitianism" (Chetty and Rodríguez 2015, 2). Other works associated with this group by Lorgia García Peña (2016), Edward Paulino (2016), Amelia Hintzen (2016), and Anne Eller (2016) have all bridged the Dominican-Haitian divide in their focus on challenging the univocal narrative of antagonism, while not losing sight of worrisome inequalities. A further goal of these projects is to situate their readings within global imperial and racial projects (Sawyer and Paschel 2007) to "illuminate rather than obfuscate" (Chetty and Rodríguez 2015, 2) these problematics. The present project is situated in these efforts. To date, these works have focused largely on historical and literary examinations and no grounded ethnographic study of the entanglements among blackness, Haitianess, and dominicanidad exists.

Even more so, Dominican racial identity is premised on the racial mixture of African, European, and Indian ancestries. Few Dominicans deny the "fact of their blackness" by virtue of this foundational myth. However, blackness is embraced mainly in terms of the folkloric past. Many of the works on the African heritage on the island focus on the slave period, African religions, and musical forms in ways that relegate Dominican 
blackness to the past rather than as a modern racial identity (Austerlitz 2006). More often, although "black cultural practices—such as Dominican Vodú—are important components of national culture, these practices are not recognized within official versions of Dominican uniqueness that affirm the nationalist myth that Dominican culture is exclusively white, Spanish, and Catholic" (Baker 2006, 57). The lack of positive historical or contemporary accounts was seen as a particular deficit to promoting Black identity as, Alicia the Reconoci.do said, ¿Quien quisiera ser negro si ser negro solo significa ser esclavo? ("Who would want to be Black if being Black only means being a slave?") Therefore, articulations of modern Black subjectivities in the Dominican Republic are limited by the national imaginary which places blackness as outside the modern nation-state through the racialization of Haitians and the relegation of black culture to the memorialized past (see Thomas 2004).

This present study enriches our understanding of mestizaje as a distinctively Latin American racial ideology as it is applied in the Dominican Republic. It does so, primarily, by examining the connections between race and nation and putting these into conversation with examinations of citizenship and illegality, topics almost exclusively discussed in relation to the United States and Europe. Moreover, by examining the multiple ways Dominicans engage with blackness, this work contributes to the goals established by the Transnational Hispaniola Working Group of challenging the simplistic and negative rhetoric of Dominican self-hatred and highlighting how Dominicans engage with both local and transnational racial formations in ways that are productive to their struggle. 


\section{The Research Project}

This work draws on over 12 non-consecutive months of ethnographic research between May 2014-October 2016 in Santo Domingo. This project is guided by three central research questions: What is the relationship between blackness and anti-Haitianism in the Dominican Republic? What transnational and diasporic racial ideologies do Dominicans have access to, and how might these present opportunities to reimagine the relationship with Haiti? How is the opposition to exclusionary policies toward Haitians utilizing racial representations in their efforts?

Much of this research was undertaken in partnership with Reconoci.do, an organized movement founded in 2010 to address the issue of denationalization of Dominicans of Haitian descent. The organization is described on its website as a Movimiento de Jóvenes Dominicanos de Ascendencia Haitiana que luchan por la reivindicación de sus derechos y el derecho a la nacionalidad (Movement of Dominican of Haitian descent youth who fight for the revindication of their rights and the rights to nationality). Reconoci.do began as a campaign sponsored by the Servicio Jesuita de Migrantes (Jesuit Service for Migrants or SJM) and housed in Centro Bonó, a Jesuit-funded educational and social service foundation that offers a wide range of programming including a library, certificate programs, Haitian Kreyol courses, assistance to migrants, public panels, and presentations. Unlike older organizations that work around issues of documentation, leaders of Reconoci.do are careful to distinguish their work from that of the hanful of non-profits that focus on Dominico-Haitian social issues. As one leader, Alicia, explains: these organizations work with the affected population, but "el factor empoderamiento no está marcadamente visible en el componente del trabajo de ellos" (the 
empowerment factor is not markedly visible in the composition of their work). ${ }^{4}$ In contrast, the model envisioned by the Jesuit Service was aimed at accompanying and empowering those affected so that ese mismo grupo pudiera seguir de manera independiente la revindicación de su causa ... yo pienso que en gran medida se ha logrado ("that same group could continue in an independent manner the revindication of their cause ... I think to a great deal that's been achieved.") Although at the time of this research, Reconoci.do remained financially dependent on Centro Bonó, one of the primary goals of the movement was to be self-funded through membership dues and thereby retain more control over their mission and projects. Dependency on external funding sources and their attendant priorities was one of the major critiques Reconoci.do's leaders had of the non-profit model. Moreover, as a movement, Reconoci.do leaders embrace direct political action and protest in constrast to what they see as the more accommodationist stance adopted by non-profits and, until recently, the sugarcane worker's union.

Although Reconoci.do has núcleos (nuclei) in five regions throughout the island (El Seibo, La Romana, San Pedro de Macorís, Santo Domingo and the southern zone [Barahona, and Barahuco]), many of the organized activities take place in Santo Domingo (see Figure 1). Each núcleo is represented by one or two coordinators who convoke meetings, communicate with the national leadership in monthly meetings, and accompany individuals through the process of restoring their documentation. The movement began with four original members of the SJM campaign; at the time of my fieldwork, each

\footnotetext{
${ }^{4}$ Interview in Santo Domingo March 16, 2016.
} 
convocation of núcleos drew 20-30 members and the 2016 National Assembly drew over 70 of the group's most active members.

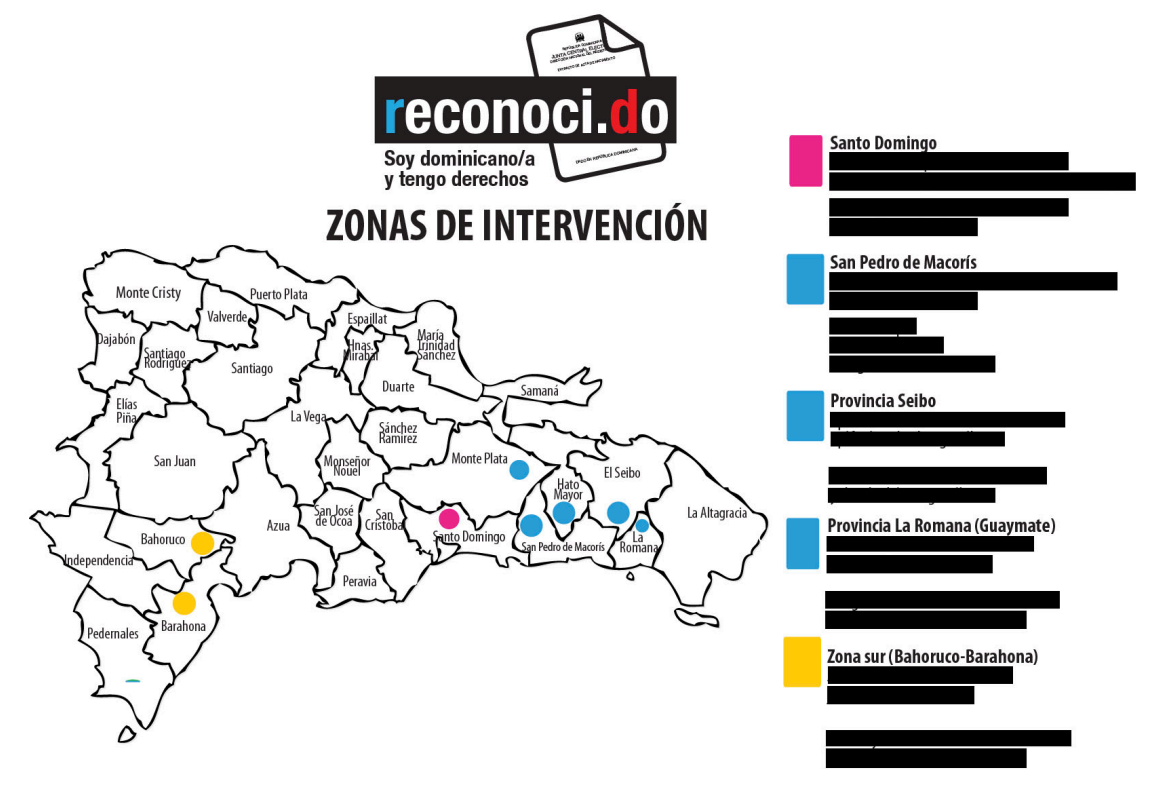

Figure 1 "Zonas de Intervención" (Zones of Intervention) Source: reconoci.do/contactos

Despite acting independently from Centro Bonó, Reconoci.do continues to rely on the center for office space, institutional support, and fundraising. Santo Domingo is also home to the central government, making it a necessary stop for many in the pursuit of their documents. For the same reason, the capital has served as the backdrop for most of the public protests organized by the organization. During my time with the organization, it organized protests in front of the Palacio Nacional, home of the president, the headquarters of the Junta Central Electoral (JCE), the Central Electoral Board, and Parque Independencia, Independence Park. Therefore, the movement's claims were largely directed at these institutions of government, which failed to guarantee the citizenship rights of Dominicans of Haitian descent. 
In addition to participating in these protests, where I took photographs and fieldnotes regarding the ways protesters framed their demands, I participated in regular meetings in all the organization's five núcleos and the annual asamblea attended by all members. These meetings offered important gathering places where members could share their successes and pitfalls in pursuit of their documentation and where the organization's vice-president along with one or more local representatives would facilitate a process whereby the impacted community learned how to connect their personal struggles with broader anti-racist, democratic, and feminist movements. The organization also increasingly sought to sponsor social events, providing opportunities to form community and gain some reprieve from the difficult political, emotional, social, and economic problems in which members were constantly embroiled. Moreover, I followed activists as they accompanied members to government offices to request their documentation.

My main contribution to the organization was as a photographer/videographer charged with documenting meetings, personal stories, and protests for the group's social media and other promotional materials. Additionally, at one point I was tasked with visiting communities to identify persons who fell into Group B, a population that the organization wanted to serve (explained later in this chapter). Throughout, I engaged in both informal and formal conversations with 11 members at all levels of the organization, including recent recruits, upper and middle leaders, and former members. These interviews were with youth, ages 21 to 30 who, except for one, had been personally impacted by the denationalization policies.

Semi-formal interviews included questions about individuals' experiences with racism and xenophobia throughout their life history, their involvement in activism, and the 
impact of denationalization on their lives. In response to the circumstances of each individual's status and history, interview protocols adapted to fit each interviewee. These interviews lasted from between 45 minutes to over two hours. In addition to events sponsored by Reconoci.do, I attended meetings and public protests of an organization that arose during my fieldwork, the Colectivo Isleño (Island Collective), a small group of friends, students, and intellectuals based in the US and Santo Domingo that was founded to bridge a divide they recognized between efforts to support Dominico-Haitians and Haitian migrants as the latter were not fully integrated into Reconoci.do. I interviewed key informants and attended meetings, protests, and events of this organization. Additionally, I interviewed key members of Movimiento de Mujeres Dominico-Haitianas (Movement of Dominico-Haitian Women, or MUDHA), Justicia Migratoria, the Movimiento de Trabajadores Domínico-Haitianos (Movement of Dominico-Haitian workers, or MOSCTHA), Centro para la Observación Migratoria y el Desarrollo en el Caribe (OBMICA), and the Centro Cultural Domínico-Haitiano (Dominico-Haitian Cultural Center, or $\mathrm{CCDH}$ ), numbering 10 interviews. These interviews with leaders of these organizations were crucial for grounding this project in the historical and legal framework of the denationalization policy. All the names of interviewees, except for those easily identifiable by their role in the movement (Ana María Belique and Miguel de Jesús Dandré), are pseudonyms.

Partnering with Reconoci.do grounds this research firmly within contemporary Dominican "citizenship projects" that are increasingly racist and xenophobic; it provides for an examination of anti-Haitianism not only through a critical reading of recent policy 
and legislative changes, ${ }^{5}$ but through those who are personally and politically committed to combatting it. My hope is that by adopting this focus this work illuminates the anti-racist and anti-xenophobic work being done on the island, efforts that are routinely made invisible in both academic and popular representations of the Dominican Republic's racial politics through narratives like that expressed in the epigraph for this introductory chapter (see also Howard 2001; Martínez-Vergne 2005). As such, this project examines DominicoHaitian antiracist struggles as at the forefront of a growing, progressive and anti-racist sector of Dominican society, refusing to reproduce a methodological nationalism that examines migrants (and the children of migrants) as "differentiated from the mainstream culture of the nation-state" (Glick Schiller and Meinhof 2011, 23). Therefore, this research offers ethnographic evidence that challenge readings which universally ascribe antiBlackness and self-denial to all Dominicans by arguing that Dominicans of Haitian descent are at the forefront of a strengthening anti-racist movement that includes allies and natural hair advocates.

If, as some scholars have argued, the meanings of blackness and Haitianess overlap in the Dominican Republic, it is necessary to examine how the broader anti-racist movement intersects with anti-xenophobic struggles. To that end, I attended four gatherings of and conducted six interviews in person and via email with activists and

\footnotetext{
${ }^{5}$ During my fieldwork, I made several requests to interview members of the Fuerza Nacional Progresista, a political organization with a nationalist philosophy that frequently organizes counter protests against Dominico-Haitians, but never received a response.
} 
individuals who promoted Afro-textured hair. ${ }^{6}$ The "natural hair movement" offers one of the few moderately organized sites where blackness is regularly and openly discussed and valorized in the Dominican Republic in ways that are not always tied to Haitianess. (Many of the handful of groups that have been organized in the capital over the last few years, including Acción Afrodominicana [Afro-Dominican Action], and the Red Dominicana de Jóvenes Afrodescendientes [Dominican Network of Afro-Descendant Youth], were defunct by the time I began this research. I interviewed a member of each of these groups for this project.) As an important racial indicator in the Dominican context, hair politics also bled into my interviews with activists and informal conversations, often hanging out in one of the many public plazas where youth gather to discuss culture and politics. Finally, when possible, I attended discussions of race, migration, and the Haitian diaspora, gaining insight into how academics, artists, and activists outside of the two main cohorts I examined were thinking about and representing these issues. Like any ethnography, this work is also informed by a diverse milieu of happenstance, intimate, embodied, and intensely vulnerable encounters with a wide range of Dominicans and non-Dominicans, neighbors, friends, strangers, tourists, and other researchers, part of the process of "deep hanging out" (Geertz 1988).

\section{A Reflexive Note}

Ethnography is an inherently "dialogic" practice (Escobar 1993, 383). Throughout this project on race and citizenship in the Dominican Republic, my own racial and national

\footnotetext{
${ }^{6}$ The term "Afro-textured hair" is used in the dermatology literature to describe a wide-range of hair textures associated with African diaspora populations. This term is useful for avoiding the imposition of a racial identification that occurs when describing hair as "Black" hair.
} 
locations posed both barriers and opportunities. To be sure, I experienced more racial privilege in the Dominican Republic than I do in the United States, where I often challenge the limits of people's racial categories as a mixed-race and multiethnic person. In the United States, I am afforded advantages because of my light skin and Anglo surname, but others rarely perceive me as an unhyphenated White person. The questions, "Where are you from? Where are you from originally? No, where are you really from? Where are your parents from?" are all features of my social interaction with US residents.

In the Dominican Republic, I experienced little ambiguity about my race. I was solidly considered rubia (literally, meaning blond but used to describe light-skinned persons). On only one occasion was I aware of being read differently when I asked a new acquaintance to guess where I was from. He said India (from the Asian subcontinent), noting the yellow undertones of my skin. My nationality, however, was less of a clear-cut issue. Some, just by looking at me, guessed I was from the US, others Spain, and a few from South America, especially Colombia. On a handful of occasions, mostly before speaking, I was assumed to be Dominican.

Although it is difficult to disentangle whether my nationality or my race were responsible for the preferential treatment I sometimes received, they likely worked in tandem. One night, I invited some of my closest friends to dinner at my apartment. Afterwards, we headed to a popular salsa club with a strict dress code. As the trip to the club was impromptu, Joel, who was wearing shorts and flip flops, worried he wouldn't be let in. Although Joel, a realtor, was middle class and trigueño, our friend Frank suggested that he enter arm-in-arm with me, who, as an americana could defy the rules more easily than he. 
At times, my race and nationality posed barriers, including the inability to do fieldwork in natural hair salons as was part of my original research plan (see Chapter 4). Some Dominicans, I found, are highly critical of the United States due to military occupations of their country from 1916-1924 and in 1965. One man, upon learning I was from the US, refused to speak with me.

In Chapter 3, I discuss the assumptions, mostly on the part of men, that I was looking for or open to intimate relationships. I was asked if I had "ever been with a Dominican man," and the man who delivered my drinking water suggested that I "had to try it." These assumptions were informed by the sex tourism economy in the Dominican Republic, mostly known to cater to European and North American straight (Brennan 2004; Cabezas 2009; Gregory 2014) or gay men (Decena 2011; Padilla 2012), but also serves women despite the little academic attention to this area (Taylor 2001). My presence as a White, US woman, traveling without her partner was often interpellated within this "economy of desire" that structures many of these interactions. I have struggled with how to write about my experiences of sexual harassment in the field, concerned that doing so would reinforce negative stereotypes that portray men of color as sexual predators. The work of feminist and activist anthropologists underscores the importance of breaking with "the discipline's implicit masculinist 'shut up and take it' mentality in reference to gendered violence in the field" (Berry et al. 2017, 538). To be sure, the Dominican Republic was not an exceptional space of patriarchal violence, and patriarchal violence is part of longstanding colonial projects. To that end, these same anthropologists emphasize how "oppressions and inequalities 'at home' are inseparable from those 'out there" (Berry et al. 2017, 558), particularly the violence of the highly exploitative tourist economy and 
broader neo-colonial relations of power between the "Global South" and the "Global North" through which my body and actions were read.

Therefore, when I was recognized as a foreigner, my presence and actions were read through this familiar script, presenting an obstacle to navigating relationships with men and generating awkward and uncomfortable interactions. Even when I was perceived to be Dominican, including in one interaction with a White foreigner who stopped me on in the street to ask if I was married, I was interpellated within the sexual economy. In this context, rapport, as a hallmark of anthropology, became difficult to establish as interest, receptivity, intimacy, and passivity in relationships with men are "constantly misrecognized as romantic desire" (Berry et al. 2017, 552) by all members of the community. This misrecognition of my actions and intentions was a pervasive danger as it held the potential to destabilize relationships of trust through potential association with the fetishizing and extractive tourist. In a more immediate sense, my interpellation within the sexual economy impelled me to adopt strategies to cultivate a sterile, professional, and asexual affective style, drawing from a cache of tactics learned in the navigation of patriarchy in the US. At times, I hesitated to challenge comments or actions that made me uncomfortable in the interest of preserving rapport with necessary gatekeepers. In other occasions, I chose to stop working with individuals who implied that their participation or support for this project was contingent on tolerating or accepting sexual overtures. To mitigate sexual harassment on the streets and in fieldwork, I attempted to cultivate a sterile, professional, and asexual appearance, sweltering in long-sleeved cardigans and avoiding conversations not narrowly focused on my research topic. I relate these few (of many) examples not to offer any truth about Dominican patriarchy, but to add to the growing 
conversation about the ubiquity of gendered violence. As the \#MeToo movement has proven, even the simple act of recognizing the ubiquity of gendered violence and its larger structural impact on women's psychological, professional, and personal empowerment is transformative. Yet, work is still needed to locate "productive ways of speaking and writing about gendered violence in the field and its intricate connections to the violence we face at home" (Berry et al. 2017, 554).

\section{Overview of Chapters}

Chapter 2 provides a brief socio-legal history of Haitian migration, pathways to legalization, and citizenship policies in the Dominican Republic. This context is crucial to placing legal and institutional efforts to restrict access to citizenship between 2005 and 2015 into a wider scope. Grounding the following analysis in the legal and historical context aids in avoiding the pitfalls Nicholas De Genova (2002) identifies in anthropological studies of "illegality" which fail to acknowledge that: migrations are primarily labor migrations, migrations are not random, but are "produced and patterned" and that "illegality" is "consitituted and regulated by law" (424). This analysis makes clear that although current citizenship laws and policies do not specifically target Haitians or their descendants, institutional practices and modes of Haitian incorporation have imposed barriers to access that especially target this group. It does so through a review of the historical scholarship, and examination of recent legal and constitutional texts that served as precedents to the 2013 ruling.

Chapter 3 evaluates the state's claims that the citizenship reforms are grounded in an attempt to modernize citizenship and naturalization policies, thereby making them more 
just, accessible, and transparent. In 2014, the state instituted pathways to reinstate citizenship for 55,000 individuals denationalized by the constitutional ruling and to naturalization for the remainder of the 458,000 Haitians and Dominico-Haitians who never obtained formal documentation. Although the state's position is that these policies demonstrate a commitment to human rights, the experiences documented in this chapter evidence otherwise. Combining observations from the implementation of the Plan Nacional de Regularización de Extranjero (National Regularization Plan of Foreigners PNRE) and women's accountings of their efforts to register their children, this analysis examines how citizenship is made through these interactions and asks what kinds of citizens are being shaped through them. Together with the previous chapter, this analysis resists the fetishization of "illegality" by a focus on the processes that produce it rather than situating undocumented persons as the "objects" of study (De Genova 2002, 423).

Chapter 4 examines the intersections between the natural hair movement and broader anti-racist and anti-xenophobic struggles in the Dominican Republic. As a marker of blackness individuals who wear their hair natural in the Dominican Republic are often marked as Haitians. By examining both recent public debates about natural hair and the ways individual women speak about their choices and experiences in wearing their hair natural, I ask whether these framings and decisions can accumulate into political and social change. Drawing on anthropological and feminist theories of the body, agency, and beauty, this chapter asks whether natural hair should be viewed as a "fad," divorced from the political and anti-racist undertones that infuse some initiates in the movement.

Chapter 5 brings these two themes of anti-racist and anti-xenophobic politics together through a historical and contemporary examination of the ways race has been 
defined in the Dominican Republic. First, I provide a detailed examination into how the state has defined racial categories over time, providing the first comprehensive analysis of the racial question in the Dominican census from 1920-1981. Second, I examine the connection between race and color through an examination of both official color designations on the cédula and in daily practice. Here, the complex and often contradictory ways race has been defined in official state documents breaks the racial "silence" around Dominicans' racial identities. Finally, I explore how Reconoci.do activists negotiate national ideologies of race and color as well as transnationally derived representations in their struggle for citizenship rights. This chapter examines how transnational activist, migration, and cultural networks influence how Dominicans of Haitian descent represent and frame blackness, and seeks to evaluate their potential to service social justice goals in the Dominican context. Largely, I focus on the limits activists identify within nationalist representations of mestizaje, or racial mixture, and opt for a politics based on blackness, even when these representations of blackness, particularly the one-drop rule, have been explicitly identified as problematic. However, while hypodescent is used in the US toward exclusionary ends, activists utilize it toward inclusionary ones.

\section{Note on Terminology}

Throughout this dissertation, I utilize the related expressions Dominico-Haitian, Haitian diaspora, and Dominican of Haitian descent. Haitian diaspora is the broadest term I employ to reference both Haitian immigrants and subsequent Dominican-born generations. I use Dominico-Haitian to reference both the second and later generations and long-term residents of Haitian origin regardless of legal status. This is the term adopted by 
several community-based organizations that work in this community. At the time of my field research, Dominican of Haitian descent was the preferred term utilized by Reconoci.do and refers exclusively to those born on Dominican territory of Haitian ancestry. As Alicia, one of the founding members of Reconoci.do informed me, the hope is that one day they will be considered unhyphenated Dominicans.

In using the term Afro-Dominicans, I am referring to those who adopt an identity as such, either in their personal identification or through their membership and/or support for groups that promote Afro-Dominican causes. In contrast, I use the term Black Dominicans to refer to Dominicans who are racialized as Black according to their phenotype. This group of Dominicans, inclusive of those of Haitian descent and those without, are the main targets of structural racism, racial violence, and prejudice. 


\section{CHAPTER 2}

\section{"UNA SENTENCIA NO PUEDE BORRAR MI VIDA": \\ DOCUMENTING THE HAITIAN DIASPORA IN THE DOMINICAN REPUBLIC,}

1920-2013

"A sentence cannot erase my life" (Figure 2), reads one of many protest signs at demonstrations marking the second anniversary of TC 168-13, commonly referred to simply as la sentencia. Exactly two years after its passage, protesters gathered in front of the Tribunal Constititucional, the court responsible for deciding the 2013 sentence that revoked citizenship for three generations of the Dominican Republic's Haitian diaspora. Most of those protesting that day had been deprived of these documents essential to the negotiation of daily life. Without them, residents cannot exercise the most basic rights and privileges as citizens and residents, such as voting, contracting legal employment, obtaining a cellphone plan, marrying, divorcing, or registering the births of children.

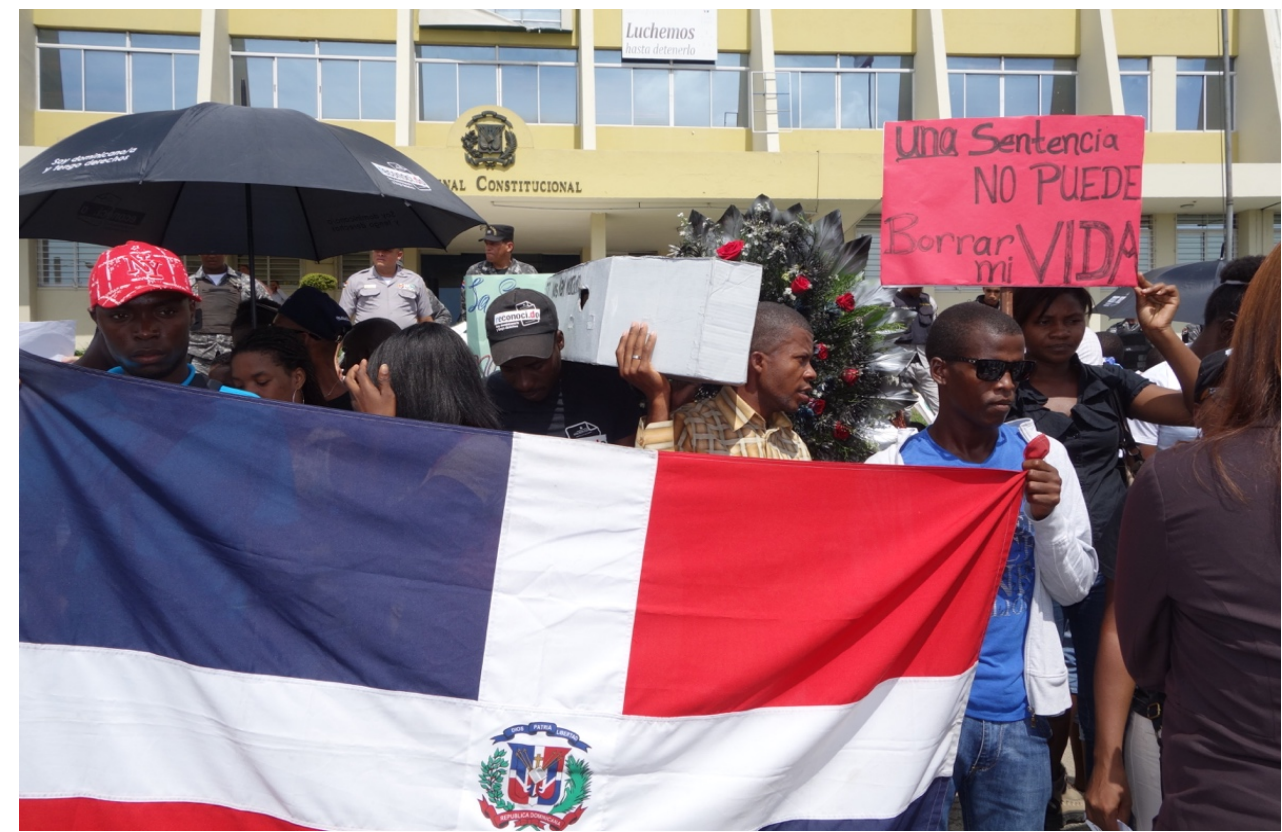

Figure 2 Protest sign in front of the JCE, Santo Domingo, DR, September 23, 2015. Photo by author. 
The protester's sign urges an examination of the sentence not only as a legal text, but also as part of a social history of the struggles for legal and political belonging by the dispossessed. Her statement asserts that her existence as a second-generation Dominican of Haitian descent is a critique of the law which renders her literally "in transit," just a visitor in the country of her birth. This statement confronts state-led efforts to render the longstanding Haitian diaspora in the Dominican Republic as recent arrivials, invizibilizing their contributions. Like generations of Haitians, mostly arriving as agricultural laborers in the $20^{\text {th }}$ century, this sign points to the contradictory practices and policies regarding Haitian legality in the Dominican Republic and the manifold tensions between the legal treatment and lived experiences of citizenship and belonging in the nation's Haitian diaspora.

Although these questions gained an unprecedented international following only in 2013, organizations working on the ground in the Dominican Republic have regarded access to documentation among their primary concerns since they began to serve this community in the early 1980s. The first Haitian civil rights organization established in the Dominican Republic in 1982, the Centro Cultural Domínico-Haitiano (CCDH), set as its primary aim "to promote recognition, in law and in fact, of the Dominican nationality and citizenship of Dominicans" (Martínez 2011, 62). A year later in 1983, the Movimiento de Mujeres Dominico-Haitianas (MUDHA) splintered off from the CCDH to address specific issues facing women and children among bateyana ${ }^{7}$ communities, where sugarcane workers are housed. Often gendered as a male space - as men were almost exclusively

\footnotetext{
${ }^{7}$ Bateyes are sugarcane plantations where workers are also housed.
} 
contracted to work on the plantations - the organization's "main focus is placed on every member of the [bateyana] community, including children of Haitian descent .... [bateyanos are] considered the largest minority in the country and is often victimized through discrimination, racism and xenophobia." ${ }^{8}$ These organizations, which have ceaselessly rallied around these issues for over three decades, make evident that before the legal basis for these measures gained an international audience, extralegal practices of denying documentation was one of the primary issues affecting the Haitian diaspora in the Dominican Republic at least as early as the 1980s.

Although this decade saw an upsurge in organizing in the Haitian diaspora, Dominicans have had to grapple with the legal and social implications of a growing Haitian presence in the country from the beginning of the $20^{\text {th }}$ century, when the first temporary workers were contracted by the US occupation forces. Rubén Silié, one of the foremost researchers on the Haitian diaspora in the Dominican Republic, has found that one of the primary issues facing this community is the state's resistencia a definer politicas claras sobre la documentación y legalidad de los migrantes ("resistance to define clear policies about the documentation and legality of immigrants") (Silié 1998, 23). Despite the clear outlining of $j u s$ soli citizenship in the 1929 Dominican constitution, the manner and extent to which policies are followed and executed have been the subject of varying state projects in direct contradiction to its own laws.

This chapter presents a brief history of the legal and social precedents of ruling TC 168-13 from the first large influx of Haitian temporary workers since the early $20^{\text {th }}$ century

\footnotetext{
8 "Mision and Vision," [sic] Movimiento de Mujeres Dominico-Haitianas, accessed June 16, 2016, http://mudhaong.org/en/mision-and-vision/.
} 
to the present. Grounding itself in the sign held by the protester quoted in the title of this chapter, this analysis is attentive to the ways that legal frameworks are the scaffolding that structure, uphold, and make possible various types of lived experiences. However, by juxtaposing individual accounts of how laws and policies were enacted and enforced, this analysis emphasizes that the law does not fully capture lived experience.

\section{Bringing the Braceros}

Although anti-Haitian prejudices were evident among Dominican elites in the late $19^{\text {th }}$ century, Haitian migration to the Dominican Republic remained largely unregulated until the US occupation of Hispaniola. Overlapping occupations of Haiti (1915-1934) and the Dominican Republic (1916-1924) by US forces and the resultant collapse of the local agricultural economy prompted the first major movement of Haitians to the eastern side of the island in the early $20^{\text {th }}$ century (Rosario and Ulloa 2006, 69). With US occupation came increased access to the US sugar market on the Dominican side of the island, and Haitian migration served a dual function of providing the labor needed for this rapid expansion and releasing some of the population pressure in Haiti caused by mounting resistance to and the destruction of the traditional peasant economy.

At this time Haitian migration surpassed the earlier Dominican reliance on West Indian labor in the US-dominated sugar industry. ${ }^{9}$ These movements undermined attempts to abate the influx of Black migrants with the migration law of 1912, which impeded visas for nonwhite populations and created agencies to promote the migration of Europeans, US

\footnotetext{
${ }^{9}$ By 1918, 7,000 West Indian immigrants were recorded in San Pedro de Macorís; by 1914, 20 percent of the population of Montecristi and by 1917, 10 percent of Puerto Plata were from the Leeward Islands (Torres-Saillant 2010, 14).
} 
nationals, Cubans, and Puerto Ricans. That same year, legislation was passed establishing Spanish as the official language of the Dominican Republic (Derby 1994). However, given the prominence of the sugar companies, it was difficult for the government to ignore their demands for cheap labor. Therefore, government ministries continued to issue migration permits directly to the enterprise, not to the migrants themselves. Due to this policy, companies were granted full control over the movement for workers and were made responsible for their return back home after the harvest.

Despite the implementation of measures meant to monitor and control the influx of Haitian workers by the occupation forces, the border between Haiti and the Dominican Republic remained porous and there was no concerted effort to monitor the use of undocumented labor on plantations (Riveros 2014, 34). By 1920, the first year these figures were registered, the Dominican census recorded 28,258 Haitian nationals (Secretaría de Estado de lo Interior y Policía 1975). The enumeration of this population was a primary step in the increasing regulation of the border, with identification becoming requisite for border crossing in the late 1920s and even stricter requirements introduced in 1930 (Derby 1994, 502).

Although crossings between the two nations remained a regular occurrence in the borderlands - particularly given the centrality of the Port-au-Prince economy to the Dominican side of the border - these new regulations began to separate unauthorized from authorized migrations in terms of the method of migration, socioeconomic class, and mode of incorporation of migrants. In other words, "they placed people in a more direct relationship to official definitions of nationhood and provided not only a new prism through 
which Haitian-Dominican contact was understood but also invisible codes of difference which could be invoked from time to time by certain groups" (Derby 1994, 502).

Despite being infamously brutal, the dictatorship of Rafael Leonidas Trujillo (1930-1961) that inaugurated the next decade is often recalled as a period in which sugarcane workers experienced relative safety from deportation. In a November 2015 presentation on cocolo $^{10}$ migration to the Dominican Republic at the Spanish Cultural Center, a site that regularly hosts events and lectures about the country's African and Haitian heritage in collaboration with local activists, artists, and anthropologists, one member of the audience related a story passed down from his father about government efforts to require that sugar estates obtain — and pay taxes for-the Cédula Personal de

\section{Identidad:}

Cuando Trujillo comenzó, pasó la ley de la cédula, era para tener control en el país, del todo el mundo, no solamente de las cocolos, y se llamaba "Ley de Camino." Había que tener esa cédula que era "ley de camino"... Los cocolos vivían en barracones y tenían una sola cédula o ley de camino y la ponian en una latita con una campanita y cómo vivían 20,30, hombres en un lugar, una sola cédula. Cuando iban a San Pedro [de Macorís], al pueblo, cogían la cédula e iban. Tocaban la campana. Cuando regresaban, tocaban la campana y ponían la cédula allí. Nunca pasó nada. Nunca iba más de una persona al mismo tiempo al pueblo, y siempre llevaban la cédula.

When Trujillo began, he passed the law of the cédula, it was to have control in the country, in the whole world, not only the cocolos, and it was called the "Law of the Road." You had to have that cédula, which was the law of the road... The cocolos lived in barracks and they only had one cédula, or 'law of the road' and they put it in a little can with a little bell and, as there were 20,30, men in one place, just one

\footnotetext{
${ }^{10}$ Previously considered a derogatory term, cocolo refers to a heterogeneous group of racialized migrants and temporary workers from English- and French-speaking islands in the West Indies, primarily the Leeward Islands, including St. Kitts, Martinique, Antigua, Montserrat, Anguilla, and Nevis (Riveros 2014, 18). See also (Martínez-Vergne 2005, 86.)
} 
cédula. When they went to San Pedro [de Macorís], to the town, they took the cédula and they went. They rang the bell. When they returned, they rang the bell and placed the cédula there. Nothing ever happened. No more than one person went to town at the same time and they always carried the cédula. ${ }^{11}$

While the focus of this work is on the experiences of Haitian workers and their descendants, this story highlights the role of three key actors shaping Dominican documentary policies and practices during this period: the state, the sugar elite, and individuals. With the implementation of the law mandating the use of the cédula in 1932, the Trujillo regime strengthened ongoing efforts to extend the state's power and surveillance, penetrating the entire geography of Dominican life. The integration of cane cutters-both long-term residents and temporary workers-reveals Trujillo's primary concern in bolstering his command and control, in contrast to alternative narratives that focus on Trujillo's more visible anti-Haitian and anti-Black discourse after the 1937 massacre. The border as a zone of potential danger for the regime is an extension of $19^{\text {th }}$ century concerns by both Haitian and Dominican leaders given "[t]he Dominican state's historic inability to define or establish territorial boundaries, coupled with nominal treaties with Haiti, had left a legacy of border autonomy and antigovernment political subversion in the region" (Paulino 2016, 50). Armed with authoritarian regime that relied on a "rigidly hierarchical central government... Haiti presented the greatest challenge to his [Trujillo's] rule" (Paulino 2016, $50)$.

Historian Richard Turits (2003) argues that Trujillo's main concern in rural policies was control, modernization, integration. Citing a 1930 survey of government-created

\footnotetext{
11 "Las migraciones forjadoras de la identidad cultural dominicana 3," accessed June 30, 2016, https://youtu.be/uQjHyHXyHdA,
} 
colonies established to settle the frontier, he argues that most beneficiaries were Haitian nationals or of Haitian descent, which "suggests an alternative construction of the Dominican nation that coexisted with official [anti-Haitian] ideals and was embraced by some local functionaries. This view of the nation effectively endowed Haitians born on Dominican soil, and even some born in Haiti, with Dominican citizenship" (Turits 2003, 155). Further, Dominican-born Haitians, and even some immigrants, could avoid paying the tax levied on migrants by demonstrating Spanish fluency.

An example of the ambiguity surrounding the question of Haitian rights is a 1934 case at the country's northern border. Responding to the petition of a Haitian-born agriculturalist, the director of the agricultural colonies granted recourse, extending the petitioner the opportunity to relocate his plot outside the border region. The Secretary of Agriculture, however, determined that the plaintiff should be evicted from his lands, rejecting eligibility for land-rights, and perhaps citizenship. Turits (2003), who documents this story, found that despite the absence of official guidelines for handling the cases of Haitian nationals with demonstrated ties to the country, such restrictive interpretations of Haitian rights and belonging were uncommon (156). However, the border area became increasingly contested and even those of Haitian descent who held identity papers were often relocated to the interior in efforts to weaken the Haitian influence in the region. Therefore, while the rights of temporary workers and their descendants remained unclear, and access to these privileges was determined by some local functionaries, clear prohibitions on the granting of citizenship rights were inexistent during this period.

Institutional control over migration and the opportunities for participation provided by the cédula were key to legitimating the claims to the nation for those willing and able 
to demonstrate loyalty to the Trujillo regime. Although the cédula was widely considered one of the most odious features of daily life (Derby 2009, 159), for the Haitian diaspora in the Dominican Republic, the access that many, although not all, were granted provided new avenues to legitimate their claims to citizenship. However, the practice of withholding this documentation, either by the central government or plantation officials, as in the narrative of the cocolo above, had significant consequences. Rural elites resisted the increased regulation of the border and migrants, particularly the requirement that they provide a cédula, at a cost, to each worker. Duplicitous practices, such as the sharing of a singular cédula described above, demonstrates both the opposition of rural elites to the encroaching arm of the state in their domain of power and the difficulties the central government had in regulating the sugar industry. Failing to provide adequate documentation restricted the government's ability to track and regulate the foreign immigration upon which the ingenios (sugar mills) depended and often aided them in evading their responsibility to arrange and pay for the return of workers after the harvest. Although in the 1930s several laws were passed to restrict the number of foreign workers in response to the global economic crisis after the boom years of World War I, the workforce remained unchanged, as these same laws enabled the Executive Power to continue to issue permits directly to the sugar companies beyond the legal limits placed on the contracting of braceros (laborers) (Riveros 2014, 35).

The anecdote exemplifies how within the conflicts between the state and economic elites for the control over Haitian migration, the migrant was often the biggest loser. The withholding of legal documentation compromised both the physical and social mobility of workers, as they were subject to arrest if caught without it. "This may explain why the 
cédula was called in popular parlance the papel de camino (the paper of the road) since it enabled movement in social status as well as in territorial space" (Derby 2009, 159). That the cédula contributed both to control and the improvement of social status is evident in that it was the preserve of men until 1940. Its creation was only one facet of Trujillo's modernization plan, bolstered by the promotion of national loyalties. In the absence of a widely literate population and limited access to the interior, the cédula played an important role in fostering a national imaginary — even among the cane cutters who were obligated to carry them and who were otherwise marginalized.

These documents also catalyzed a national racial mobility as they "fixed" the racial identity of the population. The same year the cédula was first issued, a survey of racial classification practices in the Cibao region found "the following classification of colors: White, Indio, light Indio, dark Indio, Mulatto, red Mulatto, and Moreno (dark) ... Very few identify themselves as black, except for those who are Haitians or from the English colonies" (Turits 2004, 311). ${ }^{12}$ These documents supplied the means for an official racial self-definition at the individual and national scales, and provided tangible evidence of this national racial identity to all those who carried the document. In the experience recalled by the cocolo-descendant, the ability of an entire barrack of men to utilize the same document without detection, or concern of the authorities, also represents the erasure that accompanies their undocumented status. Furthermore, these documents helped fashion an increasing national—and racial—differentiation between Haitians and Dominicans and

\footnotetext{
${ }^{12}$ The results of the 1935 census confirm that most Dominicans identified as "mestizo" (Turits 2003, 311). Contemporary policies and practices for assigning color on the cédula will be discussed in Chapter 5 .
} 
other racialized migrants through the increasing prominence of the indio category and the imputation of blackness onto national others.

In this first decade of Trujillo's dictatorship, several measures were emplaced to begin to control, and in some instances, restrict the influx and settlement of Haitian workers who began to arrive in large numbers during the US occupation. Even as the Trujillo regime gained more control over Haitian migration in this period, questions of economic utility and loyalty to the authorities were the early considerations in the granting of the rights and protections of citizenship. Therefore, the early years of large-scale Haitian migration witnessed few attempts to regulate and monitor migration across the border. The efforts that were made often empowered the sugar companies, which sought cheap labor to regulate the movement of workers from their recruitment and stay. Access to documentation became mandated and, although historical evidence shows that it was often withheld to restrict the freedom of social and spatial movement of migrants, it provided proof of residency and allowed those who possessed it to access social resourcesparticularly the civil registry for children born in the country. The dependency on the sugarcane companies for documentation also posed particular obstacles for women who, according to a representative of MUDHA, no podía adquirir derechos como el hombre trabajador. Si se murió, ella se fue deportada a Haití (she couldn't acquire rights like the working man. If he died, she was deported to Haiti). ${ }^{13}$

\footnotetext{
${ }^{13}$ Author's interview with MUDHA representatives, Santo Domingo, July 14, 2015.
} 


\section{Dispossession and Dominicanization at the Border}

After the 1937 Trujillo-perpetrated massacre targeting the Haitian diaspora in the Dominican borderlands, access to citizenship for Haitian migrants was significantly transformed. Most contemporary analyses of race and anti-Haitianism in the Dominican Republic locate the massacre as the purest reflection of if not the racist and xenophobic attitudes of the entire population, than those of the country's elite (see Paulino and García 2013; Turits 2002, 2003). The massacre clearly carved out a central space for anti-Haitian rhetoric in Dominican politics. Before the events of late 1937, travel between the island's nations was relatively unregulated; afterwards, it was restricted for both Dominicans and Haitians. The massacre of the 17,000 Haitians, Dominicans of Haitian descent, and Black Dominicans ${ }^{14}$ attempted to impose homogeneity in the heterogeneous Dominican borderlands.

Of the few antecedents of these gruesome events was an initiative to Hispanicize the names of dozens of border towns with towns such as L'Eau Noir and Bananes renamed for their literal Spanish translations, Aguas Negras and Banano (Derby 1994; Paulino 2016; Turits 2003). These efforts had only marginal success, as Derby finds that even six decades after these official changes, many at the border continued to use the towns' former names (1994, 512). Ironically, shortly before the massacre, Haiti and the Dominican Republic

\footnotetext{
${ }^{14}$ The numbers of those massacred are highly contested. This figure is taken from Turits (2003), who came to this estimate using several sources and methodologies. Edward Paulino (2016) also uses this figure. The Library of Congress country study estimates 5,000 to 12,000 deaths (2001, 24). Historian Frank Moya Pons $(1998,368)$ puts this figure at 18,000 . Dominican officials have argued that the Haitian government inflated these figures as it was paid reparations totaling $\$ 525.000$ in an agreement made in the year following the massacre (see Legación República Dominicana Washington, 12 December, 1937, "La verdad sobre la masacre haitiana" Colección Bernardo Vega, Archivo General de la Nación No. 031-029, http://200.26.174.77/cbvnode/app.html\#/details).
} 
formalized the first border treaty that had been a source of contention; previous administrations' talks had broken down between Presidents Horacio Vásquez and Louis Borno in 1929. Inheriting this issue from his predecessor, Trujillo was determined at the outset of his administration to demarcate the border. One observer attributed his success in negotiating with the neighboring government to Trujillo's “" pride to be of Haitian stock,"” which he proclaimed in the press (Paulino 2016, 54).

Despite these initial indications that Dominican elites increasingly sought to clarify the border demarcation, many described the massacre as a surprise. Historian Bernardo Vega's thorough examination of the archive in his three-volume examination of the relationship between Trujillo and Haiti has failed to locate any negative mention of Haiti in the Dominican press leading up to the genocide (Vega 1988). To the contrary, the Trujillo regime, which exercised almost total control of the media, was overwhelmingly laudatory regarding Haiti (Paulino 2016). The element of surprise, however, was integral to the logic of the massacre. Officials exploited existing tensions regarding theft of cattle, for which Haitians were often scapegoats, and Haitian economic domination. An official report from 1938 exemplifies the ways that Haitians were criminalized at this time, as such expert thieves that they steal "'the pillows and clothes underneath the heads of those who are sleeping, and steal the cédulas from the men who have inside them the money to renew them"” (Paulino 2016, 98). This criminalizing language was related to undermining Haitians' citizenship claims.

Under the guise of addressing this issue, Trujillo ordered plainclothes military officers to terrorize anyone who appeared to be Haitian. The official version of events distributed to members of the foreign service abroad argued that the suddenly heightened 
military presence in the area was due to an executive order to begin deportations of Haitians after a tour of the area had left Trujillo in shock over the number of Haitians residing there. The violent eruptions that concurred with this initiative were characterized as a spontaneous response from scorned Dominicans (Paulino 2016, 71) in efforts to stoke nationalist fervor. Most of the border's residents of Haitian origin were, at this time, born on Dominican soil and under law, Dominican citizens by birth. These narratives represent the budding imposition of notions of deportability and illegality that would become key components in the narrative about Haitians in the Dominican Republic in the coming decades. Although no formal restrictions regarding citizenship rights for Haitians and their children were introduced in this period, the massacre was executed without regard for legal status.

In the campaign to indoctrinate the border populations with the government's newly-adopted anti-Haitian ideology and to promote the specter of a popular uprising, local residents were often recruited to aid in the killing and were provided arms and shells by the local military in exchange for severed ears as proof they had participated in the massacre (Paulino 2016, 65-66). By 1937, after over a century of unrestricted migration and resettlement, the border had become a space with its own transnational culture, economy, and governance (Derby 1994; Paulino 2016; Turits 2003); the massacre, as Richard Turits describes it, destroyed a world "to a large extent apart from the rest of the nation" $(2002,600)$. In these frontier areas, Dominicans and Haitians had long lived, worked, and formed families together, to the extent that determining who was Haitian was often a matter of great difficulty. Given these interconnections, many Dominicans defended and protected their Haitian neighbors and kin during these events (see Paulino 2016). An 
alternative name for the slaughter, the "parsley massacre," is derived from a test originally designed to determine who should pay the migration tax by demanding that the subject correctly pronounce Spanish words with rolled $r$ s such as perejil (parsley). Therefore, while the massacre furthered a nationalist project on the border that excluded Haitians because of nationality, ethnicity, and language, many Dominicans were also targeted given that Black skin is often shared by both groups. As Derby (1994) argues, the transformation of this territory from an amorphous frontier to a fixed border was the impetus for a reorganization of difference in the nation in ways that transformed horizontal relationships with Haitians at the border into hierarchical ones marked by racialized difference.

Beyond those killed in the attacks, an estimated 10,000 fled to Haiti as news of the events spread, leaving behind their lands, animals, homes, and belongings. The overall demographic impact was substantial. Whereas the 1935 Dominican census recorded 52,657 Haitian immigrants, there were only 29,500 in 1950 . Notwithstanding the concentration of these atrocities at the border, localities in the interior, including sectors of Santiago de Caballeros, San Francisco de Macorís, and Puerto Plata in the north, were also targeted. Mostly aimed at stoking the fervor of Dominican nationalism that became synonymous with Trujillo himself (see Derby 2009) and consolidating Dominican dominance over the thriving border economy, the massacre also broadcast a clear message about the place of Haitians in Dominican society and economy. Even though the "urban elite class included many Haitians" (Derby 1994, 514), their wealth and lands did not provide them protection in a society marked by strict class divisions, but rather made them targets in the raids. The centrality of Haitians and Haiti to economic life at the border was a source of concern for the Dominican government behind the massacre. Port-au-Prince, the Haitian capital, and 
markets closer to the boundary were considered more accessible and thriving than those on the Dominican side, and the Haitian currency was the unit most frequently used in the in the border region (Derby 1994, 516).

Despite the wide reach of the killings and an overwhelming concentration of Haitian residents, those living in the sugar bateyes were only targeted in one documented case (Turits 2003, 170). Rather, in the weeks following the massacre, two sugar mills were authorized to contract 1,500 Haitian and West Indian workers (Paulino 2016, 68). In 1920, most Haitian migrants (71\%) were located at the border; by 1956, less than a third occupied the border zones (Martínez 2006, 10).

Following these events, both island governments agreed upon new migration regulations with stricter documentary requirements for crossing in both directions (Riveros 2014, 35). Two years after the massacre, the Dominican Migration Law of 1939 dramatically raised the immigration fee from the six pesos established in 1932 to 500 pesos levied only on non-Caucasian immigrants (Turits 2003, 170). As an exception to these measures, foreign migrants could avoid these strict requirements by migrating as braceros (laborers), whose only requirement was to present proof of their nationality. These measures pushed many economically marginalized and rural Haitians to migrate as highlyexploited temporary workers on plantations or without official authorization. Therefore, Haitians' status is the Dominican Republic was tolerated insofar as they were incorporated at the lowest economic sectors.

The massacre's most enduring significance was the consolidation of antihaitianismo as a dominant ideology in the Dominican Republic. Although it was forcefully resisted and undermined by the popular classes, "[a]fter the massacre, the 
government imposed a homogenous top-down model of Dominican identity that effectively excluded Haitians" (Paulino 2016, 57) that, in a matter of decades, would imbue across various institutions and social spaces, severely limiting Haitians' access to and exercise of citizenship rights. After the massacre, the campaign to "Dominicanize" the border continued with the institution of policies aimed at attracting European and Asian settlement in the region. The government's justification of immigration policies and settlement packages extended under the rubric of Dominicanization illustrates the ways notions of dominicanidad are wound up closely with race and ideas of racial progress. Immigrants in this region were limited to a quarter of the population, therefore the expanded access to education ensured by the Dominicanization effort, with an emphasis on a nationalist curriculum, and anti-Haitianism, was primarily aimed at integrating the mostly Dominican population in the region into the nation-state, increasingly defined in opposition to Haiti.

\section{Era of Bilateral Accords}

By the mid- $20^{\text {th }}$ century, the state, via Trujillo, would become the largest employer of foreign Haitian labor through the monopolization of the Dominican sugar industry. Concurrent with his acquisition of almost all the nation's ingenios, Trujillo negotiated an accord with the Haitian government to provide workers for these properties, renewed every five years from 1952-1986. These agreements outlined strict guidelines for the legal entrance and documentation of workers, mandating that the sugar companies cover the costs of the cédula, visa, and health certificate for each migrant, their spouse, and children below the age of 10 (Riveros 2014, 37). 
Nevertheless, it was in the interest of these enterprises not to legally register all workers on their plantations to avoid such expenses. Given the steady stream of migrants who crossed the border without the required documentation, there was an abundant supply of undocumented workers. In these cases, employees' only documentation was often the employee fichas (record cards) provided by the ingenios. This card monitored the work of the bracero, which was often piece-work, and the receipt of benefits at the end of the harvest. Upon receiving them, workers were told that these were their identity documents and "from the perspective of the employee, this was their most important document" (Riveros 2014, 38). Natalia Riveros (2014) suggests that many foreign workers may have been unaware that this was not an official identity document, particularly given the President Trujillo's ownership of the majority of ingenios.

An inflated price for sugar and increased demand for labor temporarily protected undocumented workers from repatriation for much of the regime of the outspoken antiHaitian Dominican president, Joaquín Balaguer (1960-1962; 1966-1978; 1986-1996), who rose to power as the right hand of Trujillo. Those picked up by authorities were often returned or relocated to state-owned plantations (Hintzen 2016; Martinez 1995; Riveros 2014, 24; Wooding and Moseley-Williams 2004, 41); in some cases, privately-owned plantations offered a fee to government officials to supply workers (Riveros 2014, 41). Throughout Balaguer's time in office, as Amelia Hintzen explains, legal status had less to do with documentation than occupation and "Haitians could only claim to be in the country legally if they were cutting cane, regardless of immigration status" $(2016,182)$. The escalating demand for workers encouraged those who migrated under the bilateral accords to overstay their visas, sometimes unwittingly as it was the responsibility of the enterprise 
to renew them. Increased profitability in the sugar industry also incentivized the illegal trafficking of workers across the border. When the political situation became tumultuous after the fall of the Duvalier regime (1957-1971), many Haitians established permanent residence in the Dominican Republic.

By 1990, four years after the close of final accord between the governments, President Balaguer recognized the need for a plan to regularize the Haitian migrants residing in Dominican territory. Yet, in practice, this plan served to further dispossess Haitians migrants, with reports that "many of those who registered had their documents confiscated without having previously received any identification that certified their temporary legal residence in the country. In other words, the plan seemed to have served only to attract workers with promises of regularization, but it only had the effect of taking away the documentation in their possession" (Riveros 2014, 44). This program was not only for the benefit of local audiences but was a response to increasingly vocal criticism of the conditions on the bateyes, which was threatening the Dominican Republic's privileged status in the US sugar market (Ferguson 2003).

Beginning in the late 1980s and entering the 1990s, it became increasingly difficult to register children with the ficha alone. At this point, individual state bureaucrats governed the policies regarding the acceptance of a cédula. By the mid-1980s, the unacceptability of this document to complete state functions and access rights to nationality, marriage, and education became official policy, just as it was becoming more difficult for migrants to access residency permits and cédulas. ${ }^{15}$ Instead, more official-and more difficult to

\footnotetext{
${ }^{15}$ Author's interview with Miguel de Jesús Dandre, the Dominico-Haitian civil rights lawyer who represented Julian Deguis, Santo Domingo, December 17, 2016.
} 
obtain — documents began to be required, such as passports and residency permits (Open Society Foundation 2010,6). This measure increased the number of births that were never officially declared in the Dominican Republic, as for many Haitian immigrants, the ficha was the only accessible documentation. One woman I interviewed in the province of Monte Plata explained that the sudden changes in the policy regarding the acceptance of the ficha allowed for the declaration of her older children, but not her younger ones. Further, this policy's impact was felt in the following decades, as subsequent generations of Haitian immigrants and their descendants would not have the documents necessary to normalize their status and that of their children.

Even so, many Haitian women in the bateyes had no access to this document, or any other form of documentation, due to frequently being excluded from the migration permit applications that employers provided to the government. Women migrating clandestinely to the bateyes were compelled to request a ficha via a domestic partnership with a man who worked for the ingenio (Riveros 2014, 40), a practice that made access to rights contingent on sexual access and domestic labor, and increased women and children's vulnerability as women were responsible for registering children. Individuals were not passive in the face of these manipulations by the state. Human rights lawyer, Miguel de Jesús Dandre, explains that due to the changes in the policy regarding fichas, beginning in this period many children were registered by people who were not their parents: "desperate parents would say, 'Look, declare this child for me. I already know that it's my child but I don't want him to be like that [undocumented]. But it wasn't fraud. It wasn't anything 
fraudulent, it's that there was no way out."16 This anecdote suggests not only resistance by those who were made most vulnerable by these policies, but also in collaboration with individuals who did possess documentation, indicating that a wider cross-section of Dominican society resisted these state efforts to deny citizenship.

The Balaguer regime dramatized its opposition to Haitian migrants through the expulsion of an estimated 35,000 people to Haiti in 1991 (CIDH 1991). For its part, the international community reproached the Dominican government for how it identified those eligible for repatriation, given that those detained were often not allowed time to present evidence of their citizenship or legal residence (Amnesty International 1992). In response, the government initiated a new plan to provide temporary work permits to cañeros (sugarcane cutters) in 1992. This time, the burden was placed on the employers to solicit and pay for the permits. As had occurred under the bracero programs (1960s-1980s), employers often failed to comply with the program to avoid both the costs of registration and to maintain an exploitable workforce. Even as the power of the sugar industry began to wane in the late 1980s with the rapid decline in the price of sugar and the mismanagement of the Consejo Estatal de Azúcar (CEA) (the government organization that oversaw state-owned plantations), sugar continued to determine the policies and laws regarding Haitian documentation. The ingenio often had unconditional control over all aspects of life in the batey, including the provision of housing, policing, and transportation. As these living quarters formed part of the enterprise, local municipalities did not exercise authority in the region. The isolation of the batey presented a further obstacle to knowing

\footnotetext{
${ }^{16}$ Author's interview with Miguel de Jesús Dandre, Santo Domingo, December 17, 2016.
} 
and excersing their rights in the country. In some of they bateyes I visited in Guaymate, La Romana, Monte Plata, and Santo Domingo provinces, local schools offered classes only up to the fourth grade and transportation in and out of the batey (to access schools or government offices) is both expensive and difficult as motorcycle ownership (the only attainable personal vehicle) was rare. As local roads are often unpaved, roads often become impassable when it rains (IACHR 2015, 127).

Regarding documentation, even those bateyes that provided healthcare services frequently refused to emit the documentation necessary to apply for a birth certificate. It was estimated that the Dominican-born children of Haitians accounted for over a third of batey residents (Martínez 2006, 42). These companies often forcefully maintained large portions of their workforce in a condition of illegality, failing to secure adequate documentation for their workers, withholding documents, and failing to arrange for the return of contracted workers. Worse, once the corporations were in the hands of the government under the CEA's management, these illegal practices did not come to an end, but were bolstered by more government-sponsored terror. In a matter of decades, the antiHaitian Balaguer had successfully reversed the practice, begun by Trujillo, of making documentation both accessible and necessary. Where the previous regime used documentation to monitor and control migrants, its deprivation was promoted to prohibit access to citizenship during the Balaguer era, closing the door to access documentation that had been open for decades. In the following decades, Haitian labor would migrate out of the bateyes and into the cities in search of employment. Sugar production, which reached its apex in the 1970s with an average yearly yield of over a million tons, was only slightly 
more than a third of that by 1991, and the economy was being reorganized around tourism and manufacturing.

\section{"Un país dentro de otro": Legal Exclusion and Rising Movements}

The sugar industry's decline forced the relocation of much of the Haitian diaspora from the social, geographical, and political isolation of the bateyes to the city centers (Petrozziello 2012). Described by Bridget Wooding and Robin Mosley-Williams as un país dentro de otro, the batey is "as isolated as possible from the rest of society, both economically and juridically" $(2004,40)$. After the decline of the sugar industry in the 1990s, batey residents no longer enjoyed the minimal social protection offered by employers or the state that heavily relied on their labor. During my visits to bateyes outside Santo Domingo, in La Romana, and Monte Plata in 2015-2016, residents described their employment as chiripero, odd jobs, noting the lack of regular employment opportunities.

Searching for employment outside of these areas, the Haitian diaspora has become increasingly visible outside the batey and a much larger concern for politicians, legislators, and the public. Following the massive deportations of 1991, these concerns fueled two similar deportation programs carried out in 1996 and 1999 (Human Rights Watch 2002, 16).

Community organizations, having formed during this period of crisis, had at this point been working over a decade in the context of the bateyes, and had started to take the struggle for documentation beyond national confines. In 1998, MUDHA, with support from the international legal community, submitted the case of Dilcia Yean and Violeta Bosico to the Inter-American Court of Human Rights. As the mothers of these two young 
girls had discovered in 1997 when they requested birth certificates for their children (then 10 months and 12 years, respectively), access to Dominican citizenship for those of Haitian descent — even those who possessed valid documents proving their identities-was conditioned on race and ethnicity. As their lawyer, Genaro Rincón, testified during the trial proceedings:

Thelma Bienvenida Reyes, the Civil Status Registrar, refused to accept the documentation because children of Haitian immigrants could not be declared, since their parents were in the country illegally. If the parents are Haitian, the children are also Haitian, since the parents are in transit. The Civil Status Registrar added that she was following orders from her superiors, which she had in writing, even though she refused to produce the document. She then commented on the "strange," "Africanized" or Haitian nature of the children's last names (Case of Girls Yean and Bosico v. Dominican Republic 2005, 26).

The registrar's statements demonstrate the connections between race and illegality that dominate the contemporary Dominico-Haitian experience. Further, this case conforms to longstanding arbitrary application of regulations to prevent Haitians' access to citizenship (see Hintzen 2016; IACHR 2015; Rodriguez 2007). However, the appearance of a Dominico-Haitian civil rights organization in front of the Inter-American Court foreshadowed the community's growing empowerment. Moreover, this trial was the first in a series of events that would lead to the 2013 decision to retroactively strip 200,000 Dominicans of Haitian descent of their citizenship. The case broke from the past in that it not only featured a local official's decision to not register children of Haitian migrants, but evidenced the rejection of citizenship based on race and ethnicity alone, even when Dominican birth was proven by state-issued documentation.

The court's ruling in favor of the girls provides an unequivocal argument against the state's selective application of the jus soli provision in the Dominican constitution. 
However, during the eight years that the international court deliberated this case, Dominican legislators approved the restrictive Migration Law 285-04. After August 2004, the law explicitly denied jus soli rights for children of undocumented residents. This was the first reform of Dominican migration legislation since 1939. Section III, Article 28 imparts that "[f]oreign women non-residents who during their stay in the country give birth to a child (a), should direct themselves to the Consulate of their nationality for the purpose of registering their child there" (Ley 285-04 2004, 11). Further, the law instructs hospital officials to provide a distinct pink-hued document to those who cannot provide a cédula at the moment of birth. These births are registered with the JCE in a Libro de Extranjería (Book of Foreigners) with no clearly defined process for establishing rights to nationality for mixed-status couples. ${ }^{17}$ In effect, this ruling requires that all births to mothers who cannot provide proof of legal residency be declared as foreign, even as the constitution maintains the right to jus soli citizenship. This law takes advantage of a broad interpretation of the "in transit" clause of the constitution, providing that all those born in Dominican territory are citizens, “con excepción de los hijos legítimos de los extranjeros residentes en la República en representación diplomática o que estén de tránsito en ella."18 Given the multiplication of barriers to residency and citizenship documents in the 1980s and 1990s,

\footnotetext{
${ }^{17}$ Discussion with officials from the Dominican Ministerio de Salud Pública (Ministry of Public Health) during the event "Registro Civil y el Sistema de Salud," event organized by OBMICA December 2, 2015. OBMICA has done extensive work on the subject of parejas mixtas (mixed status couples).

18 "With the exception of the legitimate children of foreign residents in the Republic in diplomatic representation or who are in transit in it." "Sentencia TC/0168/13," Tribunal Constitutional, accessed July 7. 2016, http://tribunalconstitucional.gob.do/sites/default/files/documentos/Sentencia\%20TC\%20016813\%20-\%20C.pdf.
} 
by the time this migration law was passed, few even long-term residents possessed the requisite documentation to claim legal status in the Dominican Republic.

In the Inter-American Court's October 2005 ruling in the Yean and Bosico case, the court emphasized that long-term residents in the Dominican Republic could not be considered perpetually undocumented and urged the Dominican government to reform its procedures regarding documentation, which the court found to be inherently discriminatory. They recommended a limit of 10 days for the application of the "in transit" clause, conforming to the 1939 specification that the law apply to foreign diplomats as well as flight and cruise ship crews. Shortly after the ruling was released, the Dominican Senate publicly rejected its contents, claiming that nationality is a sovereign issue not under the court's jurisdiction. Activists contested the 2004 law's constitutionality before the Dominican Supreme Court, which ruled in the state's favor.

Bridget Wooding (2009) refers to this process as a "test case," emphasizing the systematic denial of citizenship rights on the basis that many descendants of Haitian immigrants "do not have Dominican cédulas, they have Haitian sounding names, or they are black and speak accented Spanish" (Wooding 2009, 369). Lack of documentation is a widespread issue facing not only those of Haitian descent. The only large-scale enumeration of migrants completed in 2012 demonstrated just how widespread the issue of documentation is for both Dominicans with and without foreign parentage. The independent research group Colectivo 63, using these data, determined that 27 percent of those with one foreign-born parent lacked a birth certificate despite their eligibility under both jus soli and jus sanguinis. Those born to two parents without Dominican citizenship fare far worse, with more than half (57 percent) without a birth certificate $(2016,77)$. 
Among those living in one of the country's approximately 425 bateyes, having Haitian descent made one significantly more likely to lack documentation. Of the $97 \%$ of participants in a 2014 United Nations study who were born in the Dominican Republic, 54.7 percent of first and 47.1 percent of second generation Dominicans of Haitian descent lack a birth certificate, the most basic identity document compared to 36.5 percent of batey residents without any or immediate Haitian ancestry (Hasbún Martínez 2014, 32). Additionally, anthropologist Steven Gregory found that local activists estimated the "undocumented" population—excluding those of Haitian descent—as 32 percent of the population (Gregory 2007). In a society where documentation is increasingly necessary to the functions of social life, including harsher crackdowns on the contracting of undocumented employees in several industries, the implications of these figures is staggering. By comparison, as of 2015, less than 4 percent of the US population was reported to experience a similar condition (Pew Research Center 2017).

The new migration law's stance on this issue also contradicted previous interpretations of the "in transit" clause. After executing a 1965 study concerning access to documentation among the children of Haitian descent, government officials expressed concern regarding the provision of these documents by local functionaries. However, the Balaguer regime was limited in its efforts to bar access to citizenship by the jus soli clause of the constitution (Hintzen 2016). One director of a social organization located at the border confirmed to me that this logic regarding the interpretation of this clause was new, saying, Antes, no usaron la cosa de 'en tránsito, ' pero no declararon al hijo si el apellido era raro (before, they didn't use the thing of 'in transit', but they did not declare the child if the last name was strange.) 


\section{The Role of the Junta Central Electoral}

In March 2007, the JCE instructed its employees through Circular 017 to identify and retain documents with suspected irregularities, ${ }^{19}$ justifying such measures by claiming the organization had received reports of documents being issued to the children of foreigners who had not proved their residency in the country. ${ }^{20}$ While several of the participants in this project were impacted before this date, these were not systematic efforts undertaken with explicit instructions from the head of the JCE, but were ad hoc actions such as the mothers in the Yean and Bosico case. The suspension and inspection of documents in this manner became official policy in December 2007, according to what the JCE described as a provisional suspension of identity documents to be examined for fraud or irregularities. The results of this audit were not released until June 2015, leaving thousands without documentation necessary to work, study, travel, and exercise fundamental political rights such as voting.

In their identification of "suspicious" documents, officials often targeted individuals with Francophone surnames and dark skin, with multiple employees reporting that officials consulted a list posted in the office to identify typical Haitian names. In the municipality of Guaymate in the province of La Romana, a historic center of the sugar

\footnotetext{
${ }^{19}$ The documents called into question were not only birth certificates but were meant to include certificates of marriage, divorce, or death. In researching this subject, I have not become aware of any suspension of these documents.

${ }^{20}$ The JCE retains the original birth certificates. When proof of citizenship is needed e.g., to enroll in a school, take out a cédula, or for employment, a copy is requested at one of the JCE offices. Each copy is single-use and is valid for a limited period.
} 
industry and therefore a location with a large Haitian population, the entire staff of the local Junta Central Electoral came under question when it was revealed that the office's top officials were eliciting bribes to issue documentation to those impacted by the suspension of their documents under these policies (Moreno 2007). ${ }^{21}$ When the secretary at the Guaymate government office was asked whether children of other foreign parentage were similarly impacted by the audit, she responded, se les entrega a esas personas ... Si son hijos de ingleses sí se les entrega ... cuando el padre es, por ejemplo francés o inglés, sí. Pero, por lo general es como la doctora (la oficial civil) dice: un italiano, un francés, un americano no viene ilegal a ese país. Esa gente siempre viene con sus papeles en orden, vienen por la regla, por la linea (they emit them to those people ... If they are children of Englishmen they emit them ... when the parent is, for example, French or English, yes. But, generally it's like the doctor [the civil official] says: an Italian, a Frenchman, an American does not come to this country illegally. Those people always come with their papers in order, they come by the law, by the line) (Rodríguez 2007). These statements reveal that state institutions are imbued with both policies and beliefs that serve to block access to documentation specifically for Haitians, given that they are already presumed to be unauthorized immigrants in the Dominican Republic. This places further scrutiny and regulation within the process of identifying irregularities. Given the routes through which many Haitian immigrants arrived and the privileged access to travel that European and US passports provide, some of these assumptions about who is more likely to be undocumented may be correct. However, they are also shaped by the varying policies and practices

\footnotetext{
${ }^{21}$ Anonymous interview with author, El Seibo, March 17, 2016.
} 
regarding Haitian migration over time which have generated irregularies in access to documentation.

It is also widely rumored that during previous elections, particularly during the Balaguer regime, government officials would offer cédulas to those ineligible for citizenship in exchange for votes. During a visit to Batey Para Mara at the northern end of the city, my motoconcho (motorcycle taxi driver), Freddy explained that although his mother (of Haitian parentage) had a cédula, she lacked a birth certificate, a prerequisite for the cédula. Noting my confusion regarding her situation, he clarified although she was born in the Dominican Republic, she had been unable to obtain documentation, but in the 1970s was given a cédula, para las elecciones (for the elections), confirming rumors about corrupt practices. This irregularity in his mother's documentation created barriers to Freddy's access to acquiring his own documentation although he was born in the Dominican Republic.

The review of identity documents disproportionately targeted Haitians because they regularly placed into question the citizenship of those who had been declared with fichas. As fichas are the documents provided to workers by the ingenios, children of cane cutters, (overwhelmingly Haitian) are those most often declared with fichas. Outspoken activists have also been targeted for the suspension of documents, with some even suggesting that the policy was launched in retaliation against the founder of MUDHA, Sonia Pierre, who was the first widely publicized case (Moreno 2007). Among the targeted activists was the spokesperson for Reconoci.do, Ana María Belique. In July of 2015, the president of the JCE, Roberto Rosario, accused Ana María's parents of committing fraud when registering her birth. In a press conference aired on national television, he read the names and identity 
card numbers of Ana María's parents, claiming that these numbers corresponded to the cédula of other citizens. ${ }^{22}$ A few days after the statements aired, I asked Ana María about the accusations. She explained that she had become accustomed to the targeted attacks in the media, even by someone as highly ranked as the president of the JCE. Further, she clarified that the numbers he had read on air corresponded to the fichas her parents had used to declare her, not cédulas as her parents were not citizens. More than evidencing the use of government offices to intimidate Dominico-Haitian activists, Ana María's case also demonstrates the irregularities in this process, as not all her siblings were affected by the audit.

Almost all of those who participated in this study were impacted by the JCE audit in the intervening years before the 2013 sentencia validated the denationalization policy. All those impacted by the audit already held documentation and therefore questioned why the JCE withheld their documents. The responses interviewees received were varied. Some, like Ana María, were told that their parents lied about their citizenship status when registering their births; others were informed that their last name appeared on a list of those who should be investigated that circulated within the JCE offices, and some were directly informed that they were not Dominican, but Haitian, and thus ineligible for documentation. The testimonies of these encounters will be explored more in-depth in other sections of this dissertation.

\footnotetext{
22 "Documentos de Ana María Belique estaban en estado de falsedad según JCE," Noticias SIN, July 9, 2015, accessed July 16, 2016, https://www.youtube.com/watch?v=GDrWOCtRl8w.
} 


\section{Constitutional Change and La Sentencia}

Transformations in the procedures for registering births through the JCE and restricting migration laws in ways that disproportionately affected Dominicans of Haitian descent were "perfected" in 2010. The constitutional reform of that year changed the manner of obtaining Dominican citizenship. Now, it was necessary to inherit citizenship from a Dominican parent; it was not enough to be born in the country. These changes occurred shortly after the devastating earthquake in Haiti. The same wave of reform introduced a new judicial body, the Constitutional Tribunal, becoming the highest legal authority in the nation. One of the first major cases heard by the court was that of Juliana Deguis's, whose documents were denied under the audit by the JCE in 2008. Five years later, the court upheld the suspension of her documents by confirming the broad interpretation of the "in transit" clause to include all undocumented residents. Under this logic, because Deguis' parents were undocumented at the time of her birth, she was not eligible for citizenship. The case presented a significant setback in the struggle for documentation as it instilled these policies at the constitutional level, impacting 200,000 Dominican-born children of Haitian descent. Those affected by the decision were left stateless. ${ }^{23}$ Many had lived most of their lives as citizens, including having enrolled in college, opened bank accounts, and contracted employment - rights they were no longer eligible to exercise without documentation.

\footnotetext{
${ }^{23}$ The Haitian constitution did not recognize double nationality until 2012 and does not automatically granted it at birth. Many Dominicans of Haitian descent lack the necessary documentation to execute this process. The residency requirement constitutes a further obstacle for Dominicans who do not have the proper documentation with which to cross into Haiti. Still, many have neither resided in, or visited the country, and have little command of Kreyol.
} 
Dealing a further blow, the court anchored its argument in the "in transit" clause, which made its first appearance in the Dominican constitution in 1929 and applied its decision retroactively to anyone declared between that year and the constitutional reform of 2010. The retroactive application of this law violates accepted legal principles and invalidates the authority of the both constitution at the time of Deguis's birth and the civil procedure that granted her citizenship.

At this point, the international community vociferously denounced the issue of denationalization in the Dominican Republic. Calls for protest, boycott, and sanctions were heard throughout the island and in the diaspora. These efforts generated marginal reform, which will be discussed in more depth in the subsequent chapter. However, because the policy was determined by the constitutional court's ruling in decision TC 168-13 and is not a law, its reversal is much more difficult. Doing so in any meaningful way would require a change in the constitution or an alternative decision by the Supreme Court.

\section{"Los Humanos Valemos +K Cualquier Ley"}

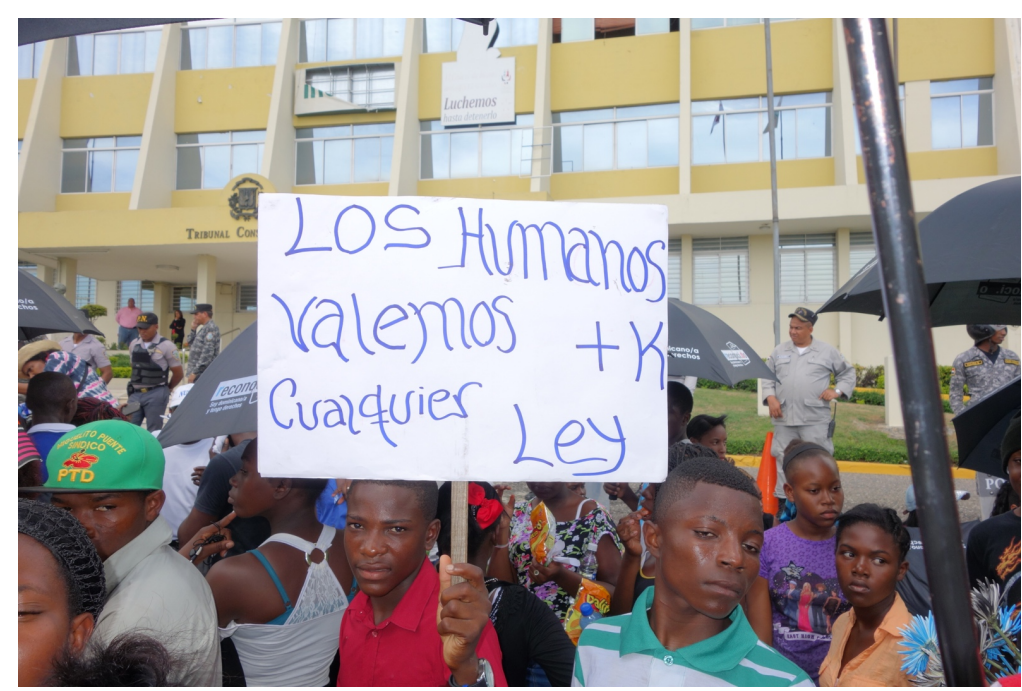

Figure 3 "Los humanos valemos mas que cualquier ley" (Humans are worth more than any law). Photo by author. 
In the JCE's final report on the 2007 audit of the civil registry, Roberto Rosario, then president, stated:

Estas condiciones generales, que afectaban a todas las personas que habitaban en esta parte de la isla, y que convivían en los espacios de pobreza y pobreza extrema, nacionales y extranjeros, sin importar su condición migratoria, indujo a muchos a interpretar que en República Dominicana habían prácticas discriminatorias, xenófobas y/o raciales, en contra de algunos segmentos poblacionales, por parte de determinadas instancias públicas, ignorando que en realidad, no era más que la expresión de una ineficiencia administrativa generalizada del Estado Dominicano, hacia los sectores de menores ingresos, que afectó a todos por igual, sin ninguna distinción, por el solo hecho, lamentable, de ser parte de la marginalidad y la pobreza que creó nuestra propia sociedad.

These general conditions, which affected all the people who lived in this part of the island, and who lived in areas of poverty and extreme poverty, nationals and foreigners, regardless of their immigration status, led many to interpret that in the Dominican Republic there were discriminatory, xenophobic and/or racial practices, against some population segments, by certain public authorities, ignoring that in reality, it was nothing more than the expression of a generalized administrative inefficiency of the Dominican State, towards lower income sectors, which affected everyone equally, without any distinction, just for the unfortunate fact of being part of the marginality and poverty that our own society created (Joseph 2015).

In this statement, Rosario insists, as much of the popular discourse, that class, not race (or national origin) is the central factor in limiting access to citizenship in the Dominican Republic. To be sure, the historical and political trajectory that unfolds in this chapter reveals how the sugar industry, at times synonymous with the state, often shaped access to citizenship for Haitian migrants. Therefore, while Rosario's statement is accurate in highlighting the central role of class in shaping access to documentation, it is inaccurate insofar as it attempts to cleave class from race. Since the introduction of Haitian labor into the sugar industry by US forces in the early $20^{\text {th }}$ century, 
This chapter set out to provide the background for the current struggles for documentation and citizenship in the Dominican Republic, particularly the evolution of civil and legal procedures during distinct epochs in Dominican history. Doing so, it showed how migration became increasingly regulated after the contracting of Haitian braceros during the first US occupation. In this initial stage of mass Haitian migration to the Dominican side of the island until the recent changes in legislation in the 2000s, the sugar industry was the strongest force regulating the movement of Haitian workers into and within the country. Even state attempts to regain control through increasing border checks and identity document requirements were foiled by the sugar companies' desires to maintain an exploitable labor pool. Although the state held a monopoly of the sugar industry since Trujillo's time, it continued ignoring its own laws mandating documentation and the return of workers after the harvest.

After the sugar industry's collapse in the early 1990s, regulating Haitian migration became increasingly important as the Haitian diaspora migrated out of the bateyes and into the cities. Through several legal initiatives and reforms, between 2004 and 2013, hundreds of thousands of people were declared ineligible for citizenship-including three generations of Dominicans of Haitian descent who had previously enjoyed their rights as citizens. The two protest signs that anchor this chapter render visible the human lives impacted by these laws. Figure 3 echoes the call for anthropologists to study citizenship as "more than just a legal-juridical set of rights and entitlements. Rather, citizenship is a set of cultural and social processes that must be examined in the realm of everyday life" (Siu 2001, 9). Therefore, the ensuing discussion will focus on the testimonies and experiences 
of young activists as they navigate the territory of exclusion both as racial and national others in the Dominican Republic. 


\section{CHAPTER 3}

\section{WITNESSING CITIZENSHIP: \\ LEGAL PROCESSES OF \\ SUBJECTIFICATION}

As the previous chapter has made clear, la sentencia is but one of many attempts to limit the Haitian diaspora's access to Dominican citizenship. Resistance to these earlier efforts was often localized due to the isolation of Dominico-Haitians in bateyes and quickly stifled through acts of state violence such as deportation. In contrast, the struggle against TC 168-13 gained traction at the international, national, and local levels. A key difference was the broad support for afectados in the Dominican diaspora, especially those in the US whose own experiences with racism, deportation, and citizenship engendered empathy for their compatriots. At earlier junctures in Dominican politics, such as during the Trujillo regime, the size and power of the Dominican diaspora were more limited. Now, prominent members of both the Dominican and Haitian diasporas such as Junot Diaz, Edwidge Danticat, and Julia Alvarez spoke publicly about the crisis and met with island-based activist leaders, generating responses to the state that questioned the diaspora's own place within the imagined community. In New York, the center of the Dominican diaspora, young Dominican-Americans organized under the banner "We Are All Dominican" in response to the citizenship crisis in their country of origin. Through protests, petitions, and social media, this group, along with local and international media, ensured that DominicoHaitian claims were not ignored.

Legal and social pressure continued to pose challenges to these policies, forcing a response by the Dominican state by mid-2014, exactly eight months after the Supreme 
Court ruling. The government's reply took the form of legislation approved by Congress and signed by President Danilo Medina on May 23, 2014. The law established two administrative processes, distinguishing between those who had been "irregularly inscribed" in the national registry (i.e., those whose documentation was suspended), and those born before 2007 to undocumented parents who never completed their registry. The law refers to these respective categories as Group A and Group B. Tied to the law which outlined the pathways to legal residency, and potentially citizenship, are instructions for the implementation of an amnesty program targeted at immigrants who had arrived in the country prior to October 2011, the Plan Nacional de Regularización de Extranjeros (PNRE) established by presidential decree just two months after TC 168-13.

This chapter is influenced by legal and political anthropology's perspective on law as "an important force in shaping human behavior ... as a constructive element 'within culture," (Geertz 1996, 35). An examination of experiences of claiming citizenship for oneself and for one's children elucidates the state's positioning around these questions and how individuals and communities gain knowledge about their relationship to the nationstate. Grounding race and gender within this analysis provides a nuanced understanding of the relationship among blackness, dominicanidad, and anti-Haitianism at the center of this study. Despite the state's efforts to characterize the most recent immigration policies as a departure from how it has approached this subject in the past (as outlined in the previous chapter), new policies continue the same historical pattern of producing Haitian "illegality", concentrating Haitians within labor sectors, and having a specific gendered effect. 
Further, because the state claims to have resolved the significant human rights issues posed by the policy via the legal changes mentioned above, an analysis of these policies is necessary for capturing their present and future implications for both formal and cultural citizenship on the island. To that end, this chapter focuses on the experiences of the groups identified in the state's 2014 response to accusations of denationalization: recent Haitian immigrants and women in Groups A and B.

\section{Bureaucratic Failures}

I arrived in the Dominican capital within a few weeks of the deadline to enter into the plan. Hoping to take advantage of the tediousness of bureaucratic processes, I frequented the Santo Domingo office of the Ministry of Interior and Police in an ominous building constructed in the brutalist style near the center of the Distrito Nacional (National District). Here, on the building's third floor, both migrants who had arrived in the country before October 2011 and those born in the country and were never registered, were required to submit a variety of receipts, forms, and testimonies proving their social, economic, and familial ties to the country. To my surprise, my first visits in late May and early June 2015 offered few opportunities to chat at length, as the process seemed to run smoothly. Clients were quickly attended and sent on their way.

As the June $17^{\text {th }}$ deadline approached, the ministry and the surrounding streets were transformed. Barricades reinforced by heavily armed national police replaced the open access I witnessed a week earlier, when no more than a few dozen applicants were waiting at any given time. With just two days before the plan would close, the atmosphere was tense with the realization that some would not reach the building's interior before the 
deadline. Similar obstacles were reported at many of the other 36 sites planned to service applicants. For the first third of the 90-day plan, only 11 of these centers were functioning. Halfway through, only two-thirds were operational. Even with these open, the border area, home to the largest concentration of Haitian immigrants in the Dominican Republic, remained among the least-served (Riveros 2015, 151). Considering these logistical failures, the Dominican government granted a 45-day extension to meet all the requirements for those who had succeeded in initiating their applications.

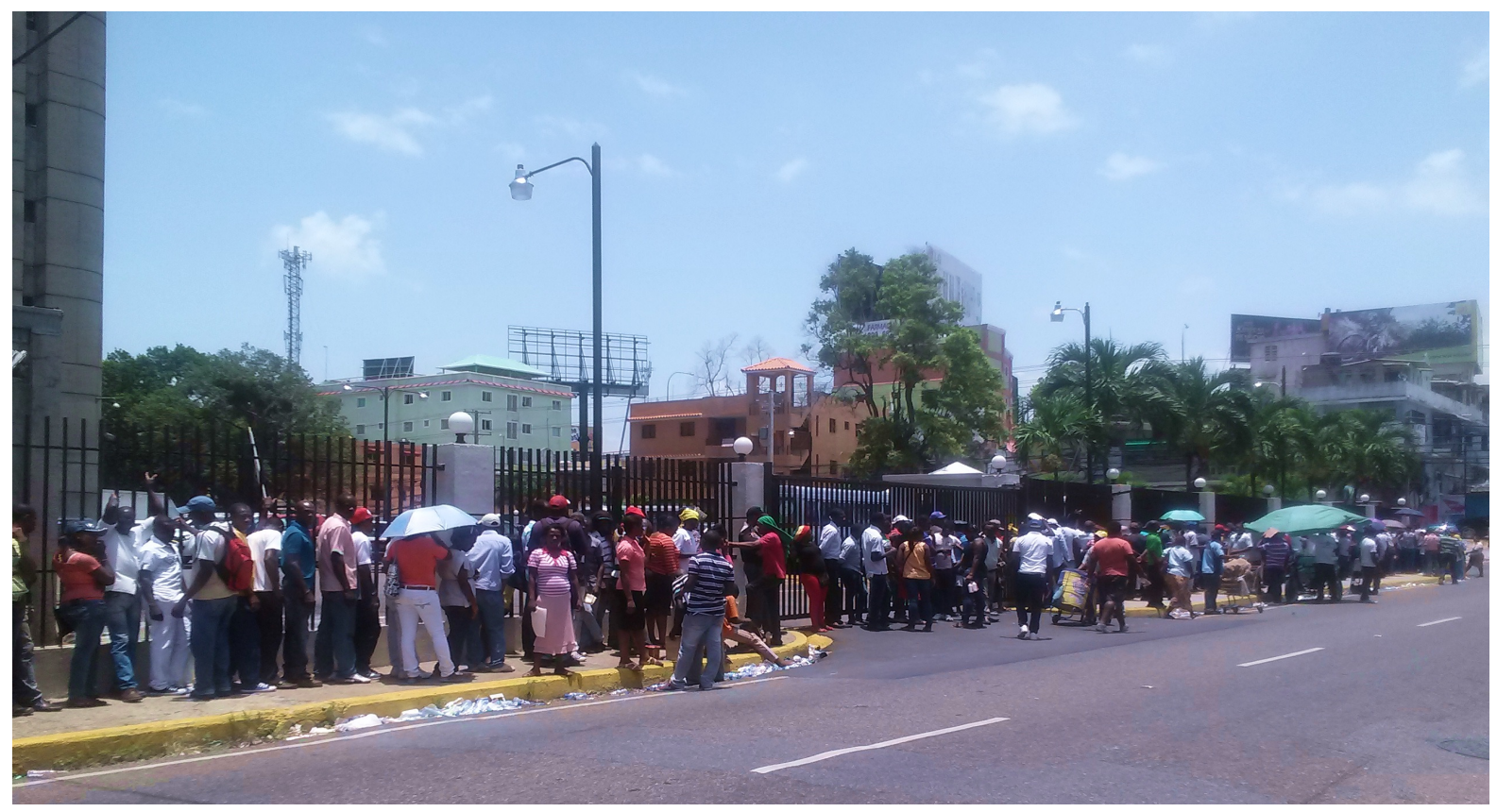

Figure 4 "Lines outside the MIP" This photo is taken from the eastern side of the MIP and after the 45day extension of the PNRE. 08.02.2015. Photo by author.

In it's language, neither the denationalization policy or the regularization plan is race-specific. However, few of those languishing in the punishing heat and sun outside the building's gates were of other nationalities aside from the Haitians and/or not Black, as 
illustrated by Figure $4 .{ }^{24}$ Therefore, my presence among the mass outside the building's gate was immediately noted. While I almost exclusively occupied the rubia (a term meaning blond but used by Dominicans to refer to anyone with light skin and European features) category, my ethnicity and nationality were often topics of debate. Sometimes I was simply called out in the street as americana [American]. One suitor was so bold as to yell, “iAmericana, necesito una visa!” (American, I need a visa!), making explicit his hopes for migration through marriage. In these cases, race did not need be specified because unhyphenated Americans were almost exclusively imagined as White. While some assumed that I had come to take advantage of the massive regularization of immigrants, most thought that I was in a capacity to help them. I was struck by the mixture of ease and desperation with which they offered their personal documents for my inspection. No soy abogada ni trabajadora social, I was neither a lawyer or a social worker, I explained, discomforted by their insistence that I inspect and approve private papers. Nevertheless, they continued to show me furniture receipts, hospital forms, and the photo-copied IDs of acquaintances - all bearing witness to lives built in the Dominican Republic. Later that day, and throughout the rest of my fieldwork, I noticed how frequently this image repeated itself with both migrants and native-born men and women filmed and photographed while holding up the documentation that they have-birth certificates, hospital papers, and fichas. International media including the BBC, Human Rights Watch, Slate, and national ones such as Hoy, and Diario Libre have all published these images. In these images, those subject to the lengthy and difficult process by which the state determines who belongs and

\footnotetext{
${ }^{24}$ Although I did not survey all members in the line many of those I spoke to claimed that other national origin (Asian, European, or Latin American) received preferential treatment. I use Haitian/non-Black to account for the presence of cocolos and their descendants.
} 
more importantly who doesn't, offer forms of bureaucratic evidence that makes their lives legible to the state. For these images, as in my own experience, were not the products of a demand to "show me your papers," but offered tangible and visible evidence that they have a right to belong, a right that, in the case of Group A, has already been authenticated by the state. Even though this practice cannot be captured outside of the suspicions and denials that often accompany Haitian and Dominico-Haitian claims to citizenship, they evidence the power of the bureaucratic process to shape how citizenship is conceptualized and expressed.

The legislative and bureaucratic momentum around issues of immigration and nationality since the implementation of the 2004 immigration law signals the Dominican government's increasing preoccupation with discourses of law and order. In response to the critiques of its citizenship policies lodged by foreign governments and multi-state organizations, state representatives repeatedly defend the denationalization policy, asserting its sovereign right to manage its borders and population. In a speech commemorating the anniversary of the country's independence from Haiti in 1844, President Medina asserted, "I want to make it clear also that no other nation in the world, nor any international organization, can demand that the Dominican Republic make sacrifices to its migratory system, or any other sovereign right, beyond what is ordered by the laws and the constitution," (Planas 2015) thereby tying the ability of the nation to fulfill its destiny to the maintenance of internal and external borders. This line of defense that appeals to the values of self-rule and the necessary fairness and legitimacy of the law has been essential to the government's efforts to counter accusations of racism, xenophobia, 
and corruption. ${ }^{25}$ Indeed, neither the constitutional court's restrictive ruling nor law 16914 mention race specifically, aspects that defenders of the policies repeatedly emphasize. However, in practice, most of the people excluded from citizenship rights in the Dominican Republic since the 2007 JCE audit have been dark-skinned residents of Haitian origin.

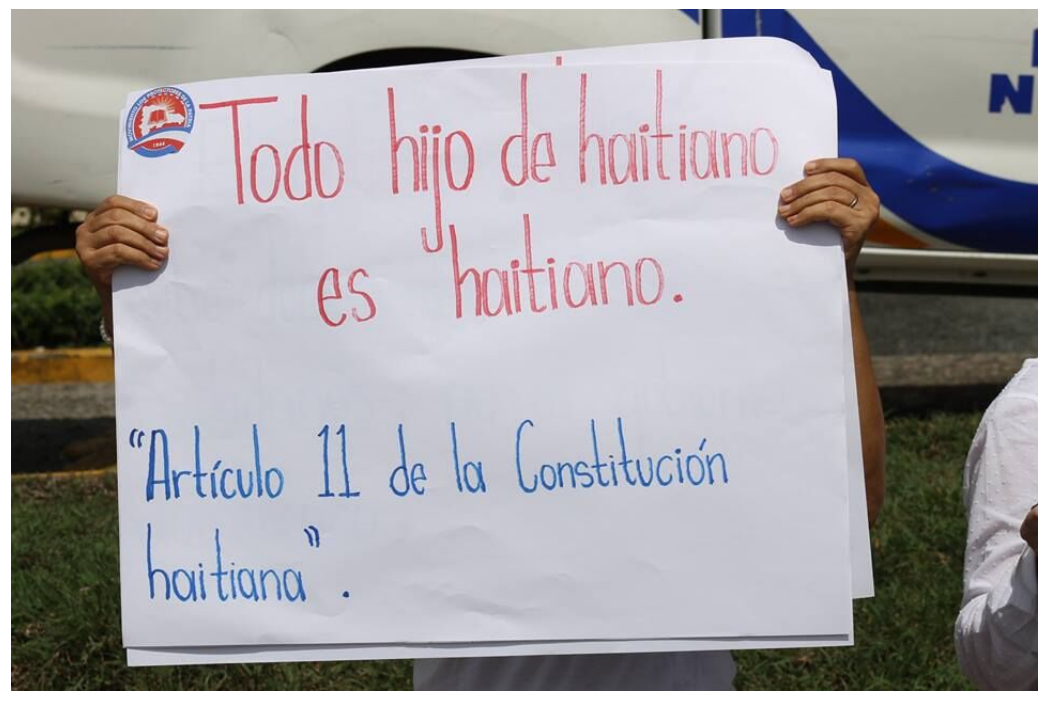

Figure 5 "Todo hijo de haitiano es haitiano" Counter-protest sign. Photo by author.

Additionally, state representatives have upheld the conviction that the proliferation of new laws and regulations concerning migration, deportation, and citizenship works in favor of human rights by eliminating the kinds of prejudice and clientalism outlined in the previous chapter. However, this view is facilitated by an understanding of racism in Dominican society that portrays inequalities as the result of individual prejudice and denies

\footnotetext{
${ }^{25}$ These assertions form part of a large-scale reform effort including a 2012 decree (490-12) that establishes a communications bureau in the president's office in charge of publicizing information about the government. This law is geared at installing a government that is "dialogante, transparente, frugal, democrático, activo, en la calle, volcado al servicio de los ciudadanos, honesto, respetuoso de las leyes y aliado de familias y negocios dominicanos en la brega diaria por su bienestar" (dialogic, transparent, frugal, democratic, active, in the street, inclined toward the service of citizens, honest, law-abiding and ally of families and Dominican businesses in the daily struggle for their well-being) (Presidencia de la República Dominicana, 2018).
} 
the role of the law, institutions, and systems in perpetuating race-based inequities. The architects of these plans fail to acknowledge that they have racial effects, even if ostensibly framed as race-neutral, as immigration policy in the Dominican Republic and much of Latin America has been the only legal area that has targeted specific racial groups. The Dominican Republic is not alone in its efforts to whiten the population via immigration, joined by Cuba's efforts to attract migrants from peninsular Spain and the Canary Islands in the $19^{\text {th }}$ century and Argentina's overtures to Italian migrants in the $20^{\text {th }}$ century. The counter-protest sign held in Figure 5 by a member of a Dominican nationalist party shows how those opposing citizenship for Haitians ground their arguments in legal discourse by using the Haitian constitution to assert that Dominicans of Haitian descent are not Dominicans.

Moreover, recent state efforts to advance, streamline, and enforce migratory policies underlie broader efforts of asserting the nation-state's modernity. David Theo Goldberg identifies "legal expression" as one of the key features distinguishing modern states from the primitive: "[1]aw, legal discourse, and legal consciousness assist in proliferating state control and discipline across the landscape and population" $(2002,139$ 140). To that end, contemporary immigration policy diverges from earlier modes of governance founded on territorial exclusion, representing a "bio-political turn" characterized by differential inclusion and the creation and maintenance of DominicoHaitians as a distinct (and subordinate) population (Martínez and Wooding 2017, 99). By drawing in a once legally illegible population via the Plan Nacional de Regularización de Extranjero, and by reconstituting the Dominican-born population through the invention of Group A and B, the state transforms its source of power from exclusion to inclusion. While 
simultaneously denying allegations of racism, the state upholds its right to "manage populations" through the elaboration and peopling of new subjectivities: Group A, Group B, "in transit," and temporary residents. Each is accompanied by a distinct legal condition, including a set of rights, and has engendered multiple postures toward the state and society. As feminist and critical legal studies scholars such as Kimberlé Crenshaw (1991) have expertly argued, law, when examined closely, often works to reproduce dominant systems of inequality. However, as the US civil rights movement, an important reference for many of the activists in this work, has shown, it is precisely for this reason that legal institutions are central sites of struggle. The first step in this struggle is to uncover the law's tacit racial effects.

The audit of registrations, while unfairly targeting Dominicans of Haitian descent, responded to concerns about inconsistencies and inaccuracies across all levels of government. In response, the current regime characterizes itself as undertaking a significant departure from these past practices. Part and parcel of this new vision for the modern Dominican state is the transformation of the former system wherein rules could be blatantly skirted and violated. As Chapter 2 showed, however, these inconsistencies in documentation often benefitted the sugarcane estates who had the most to gain from withholding documentation, not migrants. Therefore, government authorities understand the central problem of documentation to be an inefficient, decentralized, and poorly regulated system, a diagnosis that supports a broad-ranging effort to concentrate power within the central government and one that ignores issues of unequal access. Beyond the changes in birthright citizenship - effectively moving away from the doctrine of jus soli to the ideology of jus sanguinis — additional efforts to centralize and modernize power include 
the extension of presidential term limits, and the creation of the Constitutional Tribunal, the body that decided Juliana Deguis's case in 2013. In response to what has historically been a system in which local governments and individual bureaucrats exercised significant power over local registries (see Chapter 2), the proposed audit, new legislation, and increased border security (along with increased expenditures) all promised to redirect the various capillaries of power to the center and place them under centralized state control.

Anthropological studies of citizenship have long examined the relationship among the state, civil society, and citizen-subjects (Yuval Davis 1997; Ong 1999; Rosaldo 1994). Many conceive of the relationship between the citizen and the state as dialectical, shaped by the interplay between individuals and state ideologies and institutions. Anthropologists are concerned with what kinds of citizens populations are invited to become (Pérez 2015, 21) by way of the numerous state and civil society institutions that often comprise our most immediate relationship with the state.

In the case examined here, the Dominican Republic's wide-scale attempts to reconstitute citizenship have prompted new reflections, anxieties, and the formation of new types of subjects. In the analysis that follows, I explore this interplay between institutions and identities among two distinctly positioned groups: Haitian immigrants and DominicoHaitian mothers - who are responsible for the registration of children. In these interactions, the dispositions and actions required to navigate state institutions and claim rights are practiced and congealed. Grounding an analysis of the citizenship regimes in these experiences of contact renders visible the "heterogeneous assemblage or dispositif that combines forms of practical knowledge, with modes of perception, practices of calculation, vocabularies, types of authority, forms of judgement, architectural forms, human 
capacities, non-human objects and devices, inscriptions, techniques and so forth" (Li 2007, 275) through which the Haitian diasporic population is subjectified and governed. This recent shift in the management of the Dominican Republic's growing Haitian diaspora has primarily utilized legal mechanisms to "call subjectivities into being" (Goldberg 2002, 146) and integrate these new forms of belonging that lie between full and non-citizen.

In the following section I offer an illustrative vignette drawn from my ethnographic observations with the regularization process in the final week it was open when over five days, I spoke to and observed petitioners, the bureaucrats receiving them, and the police officers monitoring the crowds. As noted earlier, these observations drawn from the final days of the plan differ significantly from my early visits to the Ministry of Interior and Police. As of 2016, only 244,363 persons of Haitian descent entered into the plan ${ }^{26}$ of an estimated total of 458,233 Haitian immigrants (ENI 2012). Although the 2012 Encuesta Nacional de Inmigrantes (ENI) does not report on how many of these immigrants are undocumented, from the findings that 37.8 percent possess Haitian passports (a document necessary to apply for residency) and 23.5 percent of the second generation have Dominican cédulas, we can infer high numbers of undocumented persons at the time of the survey. These figures show the need to address issues of access to citizenship, since the government, to date, has failed to service nearly half of the population. The following discussion sheds light into some of the limitations in the implementation of the plan that demonstrate a continuity with the discriminatory policies outlined in Chapter 2.

\footnotetext{
${ }^{26}$ Ministerio del Interior y Policía, "Estadísticas generales expedientes aprobados," accessed 10 March, 2018, http://mipenlinea.gob.do/Planregularizacion/PublicDashboard.aspx.
} 


\section{"Eres blanca"}

I returned to the Ministry of Interior and Police several times as the deadline approached to gain a more grounded understanding of the events that dominated national headlines. I first encountered the line on Calle Federico Henríquez y Carvajal along the building's east side. As I turned the corner on Avenida Francia, the single-file line along the building gave way to a street so overwhelmed by people that authorities were forced to close the street to traffic. Ambulatory street vendors selling icy treats, water, sweet and fry breads added their voices to the hum of the crowd. Journalists formed their own line on the building's west side where no one was permitted to pass. I spent the next few hours speaking with various people in the line, most whom were understandably more concerned with how I could help them with their applications than my research questions. The temporary suspension on deportations the government had granted was to be lifted at midnight the next day and photos of the long yellow school buses like the ones that ferry US school children, to be used in deportation raids and emblazoned with Dirección de Migración, had been widely published in the press. Nearly all those kept out of the gates appeared to be Haitian. Conversations in Haitian Kreyol predominated and those I spoke to complained that other national origin groups did not have to suffer the same treatment. Although Haitians make up most of the country's foreign-born population (87 percent) (ENI 2012), it was clear once I gained access to the building's interior that other racial groups had an easier time gaining access given the more visible presence of lighter skinned persons in comparison with the lines outside. Inevitably, my presence as a young, lightskinned female didn't go unnoticed and nearly all of the conversations I had involved me 
explaining that I was in no position to "grease the wheels" or serve as an intermediary, a common practice in a patron-client state.

Having to repeatedly tell people I could do nothing was disheartening in the face of such visible suffering. There were no public bathrooms, food, or water. One woman with a small child showed me the flattened cardboard they had slept on the night before because she could neither afford to lose her place in line or the bus fare back to La Romana, where she lived. These appeals had sufficiently worn me down when I finally agreed to try and help Yanick, a 28-year-old Haitian immigrant from northern Santo Domingo. Eres blanca, "You're white," Yanick insisted when I told him I couldn't help him. I relented, primarily to end the conversation by proving that I had no greater chance of accessing the building than he. He led me to the western side of the building, an area that was tightly restricted by the police, to a gated side entrance where a member of the Dominican Red Cross, a few police officers, and a government employee were stationed just inside the closed gate.

Yanick's commitment to the idea that my physical appearance and US-accented Spanish were sufficient qualifications was undermined by his urging that I slip the government employee a thousand-peso note. Already concerned that I had crossed an ethical line by attempting to circumvent the process, I drew a clear line at bribery of a public official, to Yanick's disappointment. I was invited to take a seat just inside the compound, but they refused to let Yanick through. If the process was for me, I was assured, they would be more willing to help, but in this case, I had to wait for the jefa, the government employee responsible for overseeing the entire regularization process. Despite the chaos beyond the gates, the shaded spot was comfortable and the attitude among the guards was calm and relaxed. One of the officers, a 19-year old recent cadet named Manuel, 
extended a cold bottle of water and some advice. He expressed the concerns about me, a foreign White woman hanging around Haitians. I was damaging my reputation, he warned. Although I had been warned in similar contexts that Haitians were dangerous and I should be cautious, Manuel's warning implied that the danger was not Haitians themselves, but the possibility of being "contaminated," and thereby judged by Dominicans to be less worthy of respect or protection. We continued to talk about the migrants' situation, all agreed that it was tragic, but reasoned that it was the migrants' own fault for waiting until the final week to complete the process. The officers characterized them as overwhelming the regularization process, consistent with narratives of how immigrants overwhelmed other public and private institutions. When the jefa appeared, all small talk turned to seriousness as everyone perked up to attention. A woman in her 40s, the boss seemed both annoyed and overwhelmed. Without asking for any specifics of my situation, she promised that if I appeared in the same spot at 2 PM the following day she would escort Yanick and I into the building. Once outside, I shared the good news with Yanick, who appeared pleased that his plan was on track. Both exhausted from the heat and sun, before heading home he assured me that it would be easy to spot me in the crowd the next day, the only way we could meet because he didn't have a cellphone.

I arrived early the next day to continue observing the process and to talk to some of the applicants in line. The scene at the ministry that day was even more chaotic than the previous day. Within an hour of my arrival, I was talking to applicants near the middle of the line when I felt a sudden surge in the crowd. I felt people starting to push back on me and finally heard someone yell, ;Corre! ("Run!”) and the crowd rushed eastward. Someone stepped on my heel causing me to lose my shoe, but the crowd was too strong to turn back. 
I found a ledge about a half block away to rest alongside four young men. One of them bought me an icee from a vendor and explained that the police had released tear gas on the crowd for the second time that morning. Earlier, they had seriously injured an expectant mother causing her to lose her child from the impact of the canister. Although several others I spoke to that day had a similar recounting of that morning's attack, I was unable to find any newspaper reports confirming this version. Reports merely mentioned the mother being sent to the hospital but did not register any fatalities. Regardless of the truth of the event, its recounting throughout the crowd informed and reinforced the Haitian and immigrant community's feelings of mistrust of the police, vulnerability in their interactions with authorities, and sense of injustice. These rumors became an outlet for voicing their collective sense of discontent when there are few options to contest their mistreatment, what James C. Scott refers to as the "weapons of the weak" (2000[1987]). To be sure, the victims' responses were severely limited by what was at stake — their livelihoods in the country—and so the line quietly and quickly reconstituted itself.

Still unable to locate Yanick in the chaos, when 2 PM came around I decided that rather than waste the opportunity to help one of the exhausted and fraught applicants, I would try to take someone else. Roger was a tall, slender, dark-skinned youth with cornrows and a slight lisp, who had followed me that day pleading to me that I help him. To my surprise, there was no objection from the officers when Roger took Yanick's place. Later, an employee of the ministry, Antonio, who had seen me observing the process, and who would intermittently allow me access to the grounds, explained that some assumed I was being paid for my services as an intermediary. Perhaps Yanick's reading of the Dominican officials' white supremacist ideology was correct. I did not offer any money, 
favor, or courtesy in exchange for the privileges both the police and the bureaucrats extended to me.

Once in the building, the large open waiting area seemed relatively clear in comparison to the street below and offered welcome relief from the blazing sun. Roger and I were directed to some rows of green plastic chairs, where they took some preliminary information and pointed us to another narrow room where government employees took Roger's photo for his residency document. On closer inspection of the translated birth certificate emitted at the Haitian embassy, the clerk realized that Roger was just 17 years old and was only eligible to register under his parents who, as Roger explained, still lived in Haiti. ¿Por qué no me dijiste? (“Why didn’t you tell me?”), I asked Roger. He explained that he had to try as he had no other options.

Dejected, Roger, only a few days from his eighteenth birthday, was at a standstill.

I would continue to see him outside the ministry later that day when he told me he had found someone to pose as his parent if he could just get inside again. Despite my own disappointment with my inability to do anything in the face of so much suffering, Roger gave me a copy of a 2" x 2"-sized photograph as a gift for helping him. It was one of those I had seen the week earlier being taken on an exterior wall on the side of the Haitian embassy, where both men and women donned either a cream-colored or a black blazer provided by the embassy before posing in front of a white sheet tacked to an outside wall. ${ }^{27}$ The Haitian consulate provided the service to speed up applying for the passport necessary to meet the requirements of the PNRE. Before we left the building, I thought quickly on

\footnotetext{
${ }^{27}$ Although Roger was not able to regularize his status during the PNRE, he remained in the Dominican Republic and continued to call me to check in over the next several months.
} 
my feet and made sure that I could still use the favor promised to me and found Yanick as soon as I left the building. The officers at the door had changed at this point and Yanick insisted that I advocate for his pregnant sister who could not endure the long lines outside the ministry, but the guards had already decided to let pregnant women and small children inside. Eventually, Yanick was able to enter too, by insisting that he was her husband.

More than communicating the palpable human drama of the regularization program, this vignette contradicts the state's claims that the legal and bureaucratic framework it has erected is the solution to the vast irregularities and highly prejudicial ways that citizenship has historically been accessed in the Dominican Republic. As one applicant, Jean, whom I met in the early days of observing this process, noted, the chaos and obscurity of process created opportune loopholes for those with social and economic capital to gain the system. In many ways, Yanick and Roger utilized their capital as Spanish speakers who were comfortable enough to elicit a favor to gain an advantage in the process. As a medical student, David, whom I talked to after spotting him in his lab coat, demonstrated, those Haitians who evidence a certain class standing had much more ease in accessing the program. In the example related above, my inability to make claims on the state based on formal citizenship, much like those waiting in line, was mitigated by the positive perceptions of my race, class, and nationality. As my racial presentation was at the forefront of these interactions, these ethnographic snippets bring to the fore how racial privileges operate within citizenship law that masks itself as universally accessible.

Further, much of the regularization plan required documents that proved employment, social ties to Dominican citizens and institutions, and economic contributions in the form of rent, utility, and furniture receipts. For the most vulnerable Haitian 
immigrants residing in the barracones, or barracks, provided for cane workers and whose lack of documentation has pushed them into informal and low-paid work, this threshold was too high. However, this system has followed the same pattern Nicholas De Genova (2013) finds in asylum regimes where:

in systematic and predictable ways, asylum regimes disproportionately disqualify asylum seekers, and convert them into "illegal" and deportable "migrants." All such officially "unwanted" or "undesirable" non-citizens are stigmatized with allegations of opportunism, duplicity and undeservingness. The compulsive denunciation, humiliation and exquisitely refined rightlessness of deportable "foreigners," furthermore, supply the rationale for essentializing the juridical inequalities of citizenship and alienage as categorical differences that may be racialized. This social ignominy must be understood to be part of a larger sociopolitical production of migrant "illegality." Discursive formations that uphold and propagate the notion of migrant "illegality" more than mere "consequences" of a more elementary (prior) violation persistently serve as veritable conditions of possibility for the larger sociopolitical procedures that generate and sustain this "illegality" (1181).

Although this is just one account of the more than 250,000 interactions Haitian migrants had with the amnesty program, it follows the historical patterns of migration being primarily race-based. In their analysis of the regularization plan, Martínez and Wooding question whether the state's expectations for its capacity to execute such a large program were too grand or whether the plan was designed to fail $(2017,113)$. Though it might be difficult to measure intent, the results of the plan are more revealing. It has succeeded as a "spectacle" whereby already existing forms of illegality are redirected from the state to subjects who are portrayed as undeserving.

\section{Deterritorialized Citizenship}

Recent developments in Dominican citizenship policy and the international backlash it prompted diverge significantly from the reputation the Dominican Republic 
cultivated in the 1990s, when progressive academics lauded the Dominican Republic for paving the way towards a more expansive framing of citizenship by including the Dominican diaspora (but not the Haitian diaspora in the Dominican Republic). The readiness of the Dominican government to institute policies to establish and maintain political and economic ties with Dominicans abroad has caused scholars to portray it as a paragon of a transnational state (see Duany 2008[1994], 2011; Glick Schiller 1999; Itzigsohn et al. 1999; Levitt 2001; Sagás and Molina 2004; Sørensen 1996). For example, the Dominican Republic approved voting rights for expatriates in 1994, passed regulations making it easier for migrants to transport goods to the island, and incentivized resettlement by constructing housing designated for returnees (Levitt 2001). Validating the Dominican diaspora's claim to belonging and extending cultural and political citizenship required a "re-imagination" of the national community. These developments are part of the "deterritorialized nation-state" in which national and political belonging are not territorially fixed (Basch et al. 1994). While this re-imagination is made possible in part through the broadened possibilities of "simultaneity" forged by technological advancements, the role of race is key to how "deterritorialized citizenship" provides a space for diasporic Dominicans while simultaneously excluding Dominico-Haitians.

In the Dominican Republic, and much of Latin America, understandings of race and nation are fused vis-à-vis the ideology of mestizaje. Notably, mestizaje emerged in the post-independence era purportedly as a remedy for the deep racial divisions at the foundation of the colonial system. By repudiating any racial difference within the nationstate boundaries, public intellectuals like Juan Pablo Duarte hoped to foster liberal citizenship based on the principle of fraternity and equality (see Mayes 2014, 22). 
Nevertheless, this vision is more accurately one of racial homogeneity rather that "silences" racial claims (Rodríguez-Silva 2012). Scholars have long defined nationalism as a form of extended kinship, including Benedict Anderson's framing of the nation as "horizontal fraternity" (1991[1983]) to Thomas Eriksen's likening of nationalism to a "metaphoric kinship" (2010). In popular discourse, the nation is frequently rendered in kinship terms including the motherland, fatherland, brotherhood, and founding father. Eriksen argues that nationalism fills a need for community, belonging, security, and continuity to fill the void rendered by the weakened social importance of kinship $(2010,131)$. "Metaphoric kinship" relations are not just affective but must simultaneously justify a particular (real or potential) power structure. Trafficking in the language of blood and gendered hierarchies, family metaphors are always raced and gendered.

Because race and nation are so closely intertwined in the Dominican Republic, populations racialized as Black have both difficulty claiming belonging and highlighting the ways racism blocks them from attaining legal and substantive citizenship. Mestizaje binds understandings of race and nation in ways that engender the simultaneous racialization and "illegality" of Haitians. This racial logic to citizenship explains how the Dominican state can simultaneously extend rights to the Dominican diaspora while maintaining the exclusion of the Haitian one. Additionally, through mestizaje, the state maintains its status as a "racial democracy." In nationalist discourse that excludes the possibility of Haitians and unmixed blackness, Haitians cannot be imagined as members of this extended family as these lines are redrawn to include the diaspora. The inclusion of the Dominican diaspora emphasizes that territory, culture, and language are less important than blood and kinship as evidenced in the legal shift toward jus sanguinis. In other words, 
extended family ties have become the key criteria to defining Dominican nationality since the 1990s under the transnational state. The recent citizenship laws at the center of this discussion are also grounded in these entanglements between race and rights. While this point merits further study on the modes of inclusion of the diaspora, it highlights the ways inclusion is grounded in race, ensuring that Dominicans of Haitian descent are unassimilable in the eyes of the state.

\section{Engendering "Illegality"}

La desnacionalidad tiene cara de género.

Denationalization has a gendered face.

\section{- MUDHA representative}

At the global scale, birthright citizenship is the exception to the rule. Only 30 countries in the world grant automatic citizenship regardless of the citizenship status of the parent. In the Americas, where population density remained low, birthright citizenship was utilized to encourage European settlement in the colonies (Peralta 2015). More recently, birthright citizenship has come under attack not only in the Dominican Republic. For example, in 1995, members of the US Congress debated a measure to rescind birthright citizenship. Ireland and France revoked their own birthright citizenship policies in 2005 and 1993 respectively.

Women and women's reproduction are often the locus of these anxieties about birthright citizenship. In the United States, anti-immigration advocates have circulated the trope of the "anchor-baby" in which women cross the border to give birth, thereby securing birthright citizenship for their child and future citizenship for themselves through family 
reunification programs. Immigrant mothers are also blamed for burdening the already under-resourced medical system. In the Dominican context, Haitian women are equally targeted as being excessively fertile and a public burden. Articles in the Listin Diario and El Día attributed up to 80 percent of births in Dominican hospitals at the borders to Haitian women, downplaying national-level findings that in the first quarter of 2017 , only 18 percent of births were to Haitian women (Altuna Tezanos 2018; Acosta 2017). However, an Oficina Nacional de Estadística's 2016 report shows that only 5 percent of births that year were to Haitian mothers, suggesting that these other sources of data may include Dominicans of Haitian descent. ${ }^{28}$ Both articles emphasize the financial burden of births on taxpayers in the publicly funded health system. Thereby, Haitian women become the scapegoats for the failures and limitations of the publicly managed health system.

Notwithstanding that Migration Law 2085-04 eliminated birthright citizenship, which was consecrated in the 2010 constitution, state officials continue to perpetuate the stereotype of the anchor baby. The president of the Central Electoral Board, Julio César Castaños Guzmán, told reporters in 2017, "la República Dominicana tiene que decidirse a no seguir siendo un 'paritorio' de Haití, porque son miles las mujeres que están cruzando la frontera para venir a dar a luz al país, y luego buscar que esos niños sean nacionalizados" (Altuna Tezanos 2018). ("The Dominican Republic must decide not to remain a 'birthing center' of Haiti because there are thousands of women who are crossing the border to give birth and later seek for those kids to be naturalized.") These comments were made after a May 2017 resolution (03-2017) aimed at addressing what the

${ }^{28}$ Government documents regularly place Dominicans of Haitian descent in the "Haitian" category. 
government identifies as a new strategy by Haitian parents to access Dominican citizenship via their children. The government has also identified the practice of child abandonment as a growing concern, publicly accusing Haitians of abandoning their children, thereby forcing the state to grant the child Dominican citizenship because the legal status of the parents is unknown. Dominican officials believe that parents will exploit their child's citizenship when they reach the age of majority to solicit a family unification visa.

Representing women's fertility as devious is a common strategy in anti-immigrant campaigns in the Dominican Republic, the US (see Chavez 2017), and elsewhere. Such portrayals dehumanize immigrant mothers by rendering them incapable of basic human emotions such as love and empathy. Their avowed selfishness is in direct opposition to the characteristics attributed to ideal mothers: self-sacrificing and devoted. The dedication of these immigrant mothers is questioned even before they cross the border; as the medical director of one hospital reported, muchas haitianas llegan a la Maternidad con enfermedades infecciosas y de transmisión sexual, como anemia, tuberculosis, con VIH Sida, problemas respiratorios y otras complicaciones ("many Haitians arrive at the Maternity with infectious and sexually transmitted diseases, like anemia, tuberculosis, with HIV/AIDS, respiratory problems, and other complications") (Luna et al. 2017). Not only do these narratives destroy the concept of the immigrant family, thereby framing women as criminals and breeders (Lugo-Lugo and Bloodsworth-Lugo 2014), these images shift the focus away from male migration, which is sought after by powerful economic interests. Moreover, these articles ignited a public panic by identifying an increase between the 2016 and 2017 of births to Haitian women, some even attributing this growth to "tours," "mafias," or "cartels" that traffic pregnant Haitian women across the border (see Luna et 
al. 2017; Bonilla 2017). However, none of these articles points to the possible impact of immigration policies in increasing the number of mothers with documents that identify them as Haitian nationals, both those who benefitted from the PNRE (84,108 women) and those in Group B,${ }^{29}$ who were born in the Dominican Republic but given documents that identify them as Haitian nationals.

Women's experiences in maternity wards and as mothers arose at various times during my research. To be sure, the reversal of birthright citizenship policies had a disproportionate impact on the ways immigrant fertility, mothering, and sexuality were represented in news, politics, and popular culture. Undocumented women of Haitian descent, particularly those who reside in bateyes, are vulnerable at multiple levels. In my work helping Reconoci.do expand its base among residents who were undocumented before the sentence took effect (Group B), I encountered women who said that their male partners were reluctant to see them resolve their status to maintain control over them. Mariela, a resident of Batey Euskarduno, told me, "Quería estudiar, pero me casé porque no tenía documento" ("I wanted to study, but I got married because I didn't have documents"). Outside the municipal offices in El Seibo, I spoke to another mother, Regine, about the difficulty of motherhood during this process:

$\mathrm{J}:$ ¿Te sientes responsable?

R: Uh huh. Sí, porque la muchacha mía, ella, cuando ... que la profesora que le dijo no podía seguir estudiar [sic] con su papel, entonces fui a la junta a ver si la podía declarar. Fui y saqué un papel del alcalde con otro papel de acta ... entonces, vino allí y tiró foto y

\footnotetext{
${ }^{29}$ A total of 8,755 persons received residency cards under Law 169-14 that list their nationality as Haitian, although they were born in the Dominican Republic. Most lack and are not eligible for Haitian citizenship. Therefore, when women with these identity cards give birth, their children are registered in the Libro de Extranjería as Haitian nationals. Data disaggregated by gender are not available for this group (see Amnesty International 2015).
} 
firmó ... entonces cuando que llegamos buscando buscan y buscan, llaman por teléfono, los expedientes habían perdido. No estaban en Hato Mayor, aquí, tampoco allá ... Ella se puso mal, se puso mal, ya. Entonces ella fue y se casó. No siguió.

J: ¿Cómo deprimida? ¿Se puso deprimida?

R: Ella fue y tomo 40 pastillas ... Sí, cuarenta pastillas, sí. Estaba casi muerta. Cuarenta pastillas. Aspirina tomó. Entonces, llegó al médico bien grave. Entonces estuvo allí días, días allí, interna allí ... Por el papel ... Ella quería ser profesora. Pero ya no pudo. Por el papel, por su acta.

[J: Do you feel responsible?

R: Uh huh. Yes, because my girl, she, when ... when the professor told her she couldn't continue studying with her paper, then I went the junta to see if I could declare her. I went and I got a paper from the mayor and other certificate ... then, she went there and was photographed and signed ... then when we arrived searching and searching and searching, calling, the records had disappeared. They weren't in Hato Mayor, here, or there either. She got bad, she got bad then. So, she went and got married. She didn't continue.

J: Like depressed? She got depressed?

R: She went and took 40 pills .... Yes, forty pills. Yes. She was almost dead. Forty pills. She took aspirin. Then, she arrived at the doctor very ill ... then, she was there for days and days interned there .... because of the document .... She wanted to be a teacher. But she couldn't anymore [because of her birth certificate].

For Regine's child, both marriage and suicide were last resorts in what seemed like a hopeless situation with few viable options. Moreover, this was the burden Regine raised when I asked about her own feelings about being unable to declare her children. This is the burden she carries. Another woman, Yokasta, shared how her own partner forced her into sexual labor in a neighboring community housing sugarcane workers, which prohibited 
female residents. Her lack of documentation and the oppressive conditions of poverty in her community made this type of labor one of the few available options.

In the reversal of birthright citizenship, immigrant women are portrayed as overly reproductive and as leeches on the state. For nearly all the mothers of Haitian descent I encountered during my fieldwork, childbirth was often a traumatic experience due to their treatment by hospital staff. One woman, Julisa, whom I met in Batey Alemán near La Romana, was still emotionally raw from giving birth just a few months earlier. Although the group of women I was speaking with was talking about the recent deportation raids that had taken place in the batey, Julisa pulled me aside, already brimming with emotions and seeking an empathetic ear for her recent birthing experience. No había camas ("there were no beds"), she told me. Doctors forced her to give birth on the floor after which she was discharged while still bleeding. During the Cesarean birth of an older child, she recounted how the doctors had left an instrument inside her, a mistake she attributes to the rush and lack of care she experienced due to discrimination. While this experience remained at the surface of Julisa's emotions that evening, they were not exceptional in relation to her experience giving birth to her four other children, nor from the many first and secondhand stories I heard throughout my fieldwork. Beyond the persistent shortages and common stresses on hospital facilities that are common in the Dominican Republic, she understood that hospital staff further discriminated against her because of her Haitian heritage and presumed undocumented status.

Moreover, women's negative experiences extended beyond the birthing process itself. It was common that children "inherited" their undocumented status from their mothers. If a woman lacks nationality documents at the moment of birth, she is directed to 
a foreign registry, or the Libro de Extranjería, by the proportioning of a pink slip to fill out and take to the registration office located within the hospital. When Dominican fathers attempt to register their children as citizens with their identity documents, they are often turned away because their claims are suspected of being false. Hospital workers often told the couples that the mother needed to register because her maternity was undeniable but the father's was not (see Petrozziello 2015). Allied organizations have argued that this unofficial practice violates the rights of fathers to pass their citizenship status to their offspring. This claim plays into the unequal access to justice for men and women and into heteronormative and patriarchal nationalist constructions which invoke "imaginary child[ren] on whose behalf a better future is to be struggled for" (Luibhéid 2013, 149). ${ }^{30}$ Because children inherit their status from their parents, their relationships are often strained. One mother in a batey near Guaymate shared that her 18-year-old son, Ricardo, had not spoken to her in over a year, por su situación ("because of his situation"), she explained. Not only did Andrea's son find her culpable for his undocumented status, but Andrea blamed herself for not successfully protecting her son's right to Dominican nationality.

The practice of denying men's attempts to register their children was so prevalent that some women were not even aware that fathers offered a pathway to citizenship for their children. In San José de los Llanos, where I had accompanied members of Reconoci.do to the local JCE office to demand the distribution of cédulas, Yasmina, a 23year old mother, recounted the difficulties she experienced in attempting to reestablish her

\footnotetext{
${ }^{30}$ This strategy differs significantly from a more sustained focus on women's unequal access to citizenship and offers a productive means to show how gender discrimination impacts men as well as women.
} 
citizenship since 2007. After having to first leave school, re-take the eighth grade, and live without national health insurance, Yasmina continued to confront various barriers to the full exercise of her citizenship. During the eight-year period during which she tried to obtain her citizenship documents, she made trips to gather documents throughout the island because of the confusion produced by the process of transcription, which relocated Group A's citizenship documents in the registry, creating two different identities that raised flags when individuals tried to get documents for school or work:

tengo que asistir a San José de los Llanos por lo de la cédula, después tengo que ir a Santo Domingo por el certificado, pero no sé si me van a entregar, ayer yo fui a Santo Domingo, el miércoles fui también. Tuve que ir a las dos Juntas, la del distrito y a la principal. Y allá no me lo pudieron resolver y me entregaron unos documentos para entregar allá en la secretaría de la educación para que me puedan dar el certificado de cuarto pero ese papel no lo quieren recibir allá en la secretaría y me mandaron donde me declararon, a la Junta donde me declararon para que me den una certificación porque de los dos [registros].

I have to go to San José de los Llanos for the ID, then I have to go to Santo Domingo for the certificate, but I do not know if they will give it to me, yesterday I went to Santo Domingo, Wednesday too. I had to go to the two Juntas, the district one and the main one. And there they could not resolve it and they gave me some documents to deliver to the secretary of education so they can give me the certificate of fourth grade but they do not want to receive that paper in the secretary and they sent me where they declared me, to the Junta where I was declared to get a certification because of the two [registrations].

In Yasmina's estimation, transportation for these trips can cost up to 425 pesos, almost 10 USD and more than a tenth of the monthly wages for someone living at the rural poverty line (Carneiro and Sirtaine 2017). Yasmina's story is certainly not unique and was echoed by Diana, a young mother who had received her cédula when she came of legal age in 2001. However, when she went to get a copy of her birth certificate in 2007, the JCE refused to grant her one and sent her to the capital when she demanded to know why her 
request was denied. Because Diana already possessed a cédula, she had successfully registered three of her five children. She estimates that between 2013 and 2015 she went to the Junta more than 20 times, spending an estimated total of $20,000 \mathrm{RD}$, about $\$ 444$ USD.

While Yasmina's story reinforces the critique of the bureaucratic system as a principal obstacle in individual's efforts to gain residency and citizenship, despite her numerous encounters with the state she had still been unable to register her three-year-old daughter, thus perpetuating the cycle of the lack of documentation. When asked about her daughter, despite Yasmina's struggles and efforts to gain the necessary nationality documents outlined above, she blamed herself for her daughter's undocumented status: por mi culpa no está declarada... como no tengo documento no la puedo declarar ("by fault of my own she's not declared... because I don't have a document I can't declare her.”) When it was revealed by the activists I was with that the child's father could ensure her daughter's citizenship, Yasmina assumed that this was only possible if the mother was a citizen: hay muchas personas que se han ofrecido declarla pero yo no quiero ("many people have offered to declare her but I don't want them to"). For Yasmina and mothers in similar situations who often considered, were pressured into, or allowed their child to be declared under the name of a citizen friend or relative, came an attendant fear of losing that child. The child's paternal grandmother offered to complete the declaration under her name, but Yasmina forbade her from doing so, refusing to give up her right to be acknowledged as the child's mother. Due to recent policy changes that made documentation a central aspect of their lives, many turned to such strategies as a solution, if not for them, then for their children. Often, however, such strategies to retain a sense of 
stability or dignity for their families had adverse consequences, as is the case with one woman I spoke to in Batey Euskarduna, who had fraudulently claimed that she was born in Haiti because she had not managed to secure any Dominican documentation.

Under the current Dominican citizenship law, established in 2004, all mothers who fail to show proof of legal residency at the time of birth are directed to the foreign registry; however, if the father is a citizen he may register the children as such. While this policy was not the focus of my research, the number of violations is so high that in 2015 the think tank OBMICA spearheaded a public campaign to combat these violations. Although it is unclear how prevalent this practice is, several mothers I met during my fieldwork had considered having friends or family members register their children. While the burden to register births more frequently falls onto mothers, fathers are named as those responsible for the registration of children in the law (Petrozziello 2015). As the proportion of hospital births rose, registration centers were relocated to allow for registration on-site (Petrozziello 2015) using the papel de la cama (literally, the bed's paper), containing the basic information of the mother and child that is the primary proof of birth. This change, along with the widespread extralegal practice of doubting paternity claims, effectively made mothers responsible for the registration of their children, thereby placing the burden of inherited undocumented status on their shoulders. For Dominican women, especially those in marginalized communities, motherhood is an important social identity and provides one of the few opportunities for women to gain status, respect, and the possibility of financial security. As Dorothy Roberts (1997) argues, "[b]laming Black mothers ... is a way of subjugating the Black race as a whole .... devaluing motherhood is particularly damaging to Black women .... Being a mother is considered a woman's major social role" (10). The 
demonization of Dominico-Haitian women's fertility and their negative experiences during the birthing and registration process strip women of these social and economic benefits extended to mothers and which are often necessary for their survival.

The practice of refusing declarations made by fathers further strains the family as it not only prevents the recognition of children's citizenship rights but also reproduces the single-mother headed-household, which is demonized in popular representations of deviant migrant mothers noted above. Precisely because of the extralegal and discriminatory character of these denials of citizenship, women themselves often appear as the source or bearers of this problem. This gender asymmetry is reflected in the membership and involvement in Reconoci.do, where most attending meetings are women. Notwithstanding the agonies that women experience in this process, that exasperation and defeat are not the only emotions that women expressed. Rather, the amount of attention these longstanding issues had received and the organized response it engendered, have fostered renewed action among those affected. After years of facing the state alone, Diana reported that she feels she has mucha fuerza ("much force") and that the organizations gave her ánimo ("energy") to continue in a process when she felt that todo habia terminado ("everything had finished.")

This shift in official citizenship policy from jus soli to jus sanguinis makes clear that the family is a primary site in the government's management of national boundaries. Eithne Luibhéid writes that the same heteronormative logic of "reproductive futurism," which foregrounds the family in its efforts to secure "particular kinds of national futures ... justifies state interference in the sexualities, childbearing opportunities, and parenting by women of color, poor or disabled women, lesbians, migrant women, and others" 
(Luibhéid 2013, 149-150). For women who are multiply marginalized in the Dominican state, motherhood often becomes their only avenue of encounter. The experiences outlined above show that hospitals and the documentary agencies contained within them adopt practices that withhold the possibility of being recognized as "good mothers" and, therefore, claiming rights and belonging through gendered notions of citizenship. Despite the herculean efforts some mothers make in their efforts to secure documentation for themselves and their families, the state's focus on birthright citizenship as a threat to national security and sovereignty contributes to the demonization of women's sexuality and reproduction in society at large, in their families, and in their own lives.

Further, the shifting of the burden of documentation from fathers to mothers revives older forms of racialization and un-freedom, whereby the mother's status determines that of her offspring. Such forms were a prominent pillar of women's exploitation under slavery to simultaneously maintain black women's sexual availability to White men and reproduce the slaveholding system. Moreover, this same racialized logic of belonging makes it possible to imagine diasporic Dominicans as citizens and Dominicans of Haitian descent as foreigners. The intertwining of race and nation under the ideology of mestizaje has provided for the extension of the national belonging vis-à-vis a retrenchment of racial boundaries.

\section{Conclusion}

At the core of this chapter lie concerns over the ways new configurations of citizenship in the Dominican Republic — both that aimed at offering a consolidated pathway to citizenship for some immigrants and undocumented Dominican-born residents and 
restrictions on birthright citizenship shape the lives and identities of those targeted by these policies. Despite the promotion of the amnesty program and the shortened period of residency as a sign of the state's recognition of the Haitian diaspora's contribution to the Dominican Republic, the application process exhibited a disturbing disregard for these potential citizens. The long lines, incidents of abuse, and practices of discrimination and corruption demonstrated to applicants the limits of their rights even as law-abiding and authorized residents. Here, the line between legal and non-legal became blurred. Martínez and Wooding (2017) critique scholarly interpretations of these recent events that would see them as a return to the Trujillo-era atrocities against Haitian immigrants. However, their reading of the historical record only encompasses the massacre, not Trujillo's efforts to extend the state's power and surveillance through documentary practices, including the mandate to carry cédulas. Like current President Medina, Trujillo's discourse and practices often promoted order and modernity including urban planning and appeals to human rights via the resettlement of Jewish refugees. Both then, as now, documentation is utilized to produce a condition of "illegality" that forces the marginalization of Haitians and Dominico-Haitians in lower economic sectors.

Moreover, the application process grounds citizenship on one's connection to "true" Dominicans through marriage, community, or employment, which ignores the historical segregation of the Haitian diaspora in bateyes with high rates of lack of documentation. The conditions of extreme poverty and employer-provided housing, sometimes holding multiple families and generations, makes the barriers to prove economic contributions even more difficult for this population. The ethnographic vignettes supplied in this chapter promote readings of these events that contest the state's claims to 
the fairness and color-blindness of its laws, policies, and institutions. Equipped with this alternative reading, some immigrants can adopt strategies to benefit from the system, although they are among the few with access to higher education and/or foreign anthropologists.

The other group that was largely successful in regularizing their status were the cañeros, who benefitted from a strongly organized labor union and who did not diverge from their acceptable position at the bottom of the economic scale. Reflecting on the number of those left out of this process, it is easy to consider it a failure. However, as a mechanism that both silenced much of the opposition in the international community and a sorting tool that did not preclude the state from making claims to the fairness and colorblindness of the process, it could be easily rendered a success. Rather than serving as an invitation for undocumented persons to enjoy the rights and protections granted by law, this process made clear that these rights are not guaranteed but are granted at the discretion of authorities, especially for impoverished and racialized populations. Each of these narratives enrichens scholarly understanding of the ways that "illegality" intersects with parallel forms of oppression such as race, class, and gender.

New restrictions on birthright citizenship emphasize this point. The unofficial practice of linking children's citizenship status to that of their mothers recalls older patterns of tracing racial lineage and conditions of freedom to mothers. These pressures strain family relationships, both between mother and child, parents, in-laws, and other family members trying to intervene. More importantly, they deprive mothers of the positive associations and strong kinship ties associated with motherhood, transforming motherhood into a source of grief and depression. They also marginalize fathers from the process of 
documenting their children's legal status in the Dominican Republic. These unofficial procedures, coupled with the state's explicit efforts to target birthright citizenship as a key social problem, serve to demonize women and their fertility and portray them as leeches on state resources. Non-citizen women therefore cannot access discourses that would see their motherhood as a contribution to the future of the nation. In contrast, they, and their offspring, are rendered stateless with no clear path to citizenship. The experiences of both Haitian immigrants and Dominican mothers of Haitian descent illustrate the intimate connections between race and citizenship in the Dominican Republic as they are infused with gender and class. They render visible the mechanisms the state employs to render their claims on the state as illegitimate.

It remains to be seen what will come of the new registries instituted by the JCE in correspondence with these legal mechanisms. Considering these measures, activists have protested the process of transcription whereby their previous registry is voided and moved to the Libro de Transcripción. Anxieties about this process stem not only from the difficulties and confusion generated by the double-registry as described by Yanina above, but also arise from activists' concerns that their segregation in the registry makes them legible to the state in distinct ways and therefore potential targets for specific interventions. Additionally, the Libro de Extranjeria, where the children of undocumented persons are registered, generates its own set of anxieties, associated with what Donald Martin Carter refers to as the "revocability of the promise of the future" $(1997,196)$ that accompanies the precariousness of being labeled a foreigner. Given the roles of segregation, codification, and subjectification in the most recent citizenship policies, these fears are far from unfounded. What is clear is that new citizen subjectivities are being founded, ones not 
based on outright exclusion, but differential inclusion, resonating with activists' fears. Confirming their suspicions is the realization that "illegality," contrary to the way it is used in popular discourse, is not a characteristic borne in migrants (and their descendants), but is created by the processes outlined above, whereby they are "stigmatized with allegations of opportunism, duplicity and undeservingness" (De Genova 2013, 1181). Finally, although the organized movements for Dominico-Haitian rights are nascent, they also arise out of these processes. It is precisely the targeting of birthright citizenship that has led to the cementation of Dominico-Haitian identity as distinct from the larger Haitian diaspora and made its specific needs visible. In turn, the institutional knowledge gained in these struggles to access rights are key to the success of activist work. 


\section{CHAPTER 4}

"YO AMO MI

\section{PAJON":}

\section{NATURAL HAIR AND THE NATIONAL BODY}

Tu afro no cabe en la foto

"Your afro does not fit in the photo"

On June 28, 2014, an article bearing the title Tu afro no cabe en la foto was published in the Spanish newspaper, El Pais, by the Dominican activist and artist Rita Indiana. The op-ed, occupying just three short paragraphs, related the story of Gisela Paredes, a Dominican journalist who was told that she must straighten her natural hair before being allowed to take the photo to renew her cédula. After gaining wide circulation, several women added their voices to the complaint against the JCE, citing the discriminatory comments made by employees of the agency when they attempted to procure the document. Authorities had reportedly told Gisela, Con esa greña, no hay cédula ("With that mop, there's no cédula.") Others added that they were instructed to first blow dry their hair straight to sit for the portrait. The requirement that women with full, curly heads of hair should undergo hair straightening processes to access documentation goes beyond officially mandated guidelines that simply require that the forehead and ears be visible on the photograph.

Further, the instructions given to the women - that they return with their hair straightened - rather than a simple request to gather their hair suggest that to make individuals legible to the state, they must conform to ideals regarding racial belonging, represented in hair, and measured by subordination to a dominant a White racial order. 
This is a familiar pre-occupation for the JCE, which until $2014^{31}$ determined the skin color categories on the cédula. Although such cases may not be new, they gained national and international attention in 2014, given two recent developments in racial politics on the island: the growth of the natural hair movement, a loose collective, mostly women, who promote the acceptance of afro-diasporic hairstyles; and the 2013 policies that denationalize Dominicans of Haitian descent.

While not all made the connection between their treatment by the JCE and statebased policies of discrimination, some saw the obstacles to cedulación as another manifestation of the denial of citizenship rights - either legal or cultural — to Black Dominicans. Although the disenfranchisement of Dominico-Haitians reached the highest levels of government, it too had started with the refusal of the JCE to emit documents to the descendants of Haitians, often identified by the color of their skin alone.

The screen print appearing below documents these incidents to audiences in New York and Santo Domingo. Figure 6 appeared in the exhibition titled "Consequential Translations", which framed New York as a diasporic space where Dominicans and Haitians can bridge racial, ethnic, and national difference. The print features a light-skinned woman with visible African features, whose large afro takes up most of the print's space. Below a frame in which the woman's face barely fits is the same phrase from the El País article.

The massive proportion and asymmetry of the woman's afro are in direct contradiction with the same white square that fails to contain it. In contrast to the manicured

\footnotetext{
${ }^{31}$ In the 2014 redesign of the document, the color category was eliminated.
} 
round shapes of the afros from the 1960s/1970s era, the woman in the screen print has hair that grows freely in all directions, paying homage to, but suggesting a break from, the militant discipline of previous generations and disciplined beauty practices.

The determination that natural haired women "do not fit" reinforces a limited vision of the national body that excludes cultural and aesthetic representations of blackness. The rejection the afro as an appropriate national image is a refusal to recognize the place of the afro as a representation of Black politics and identity within the national body. Its regulation also reflects its power and potential danger to uproot a White supremacist political order.

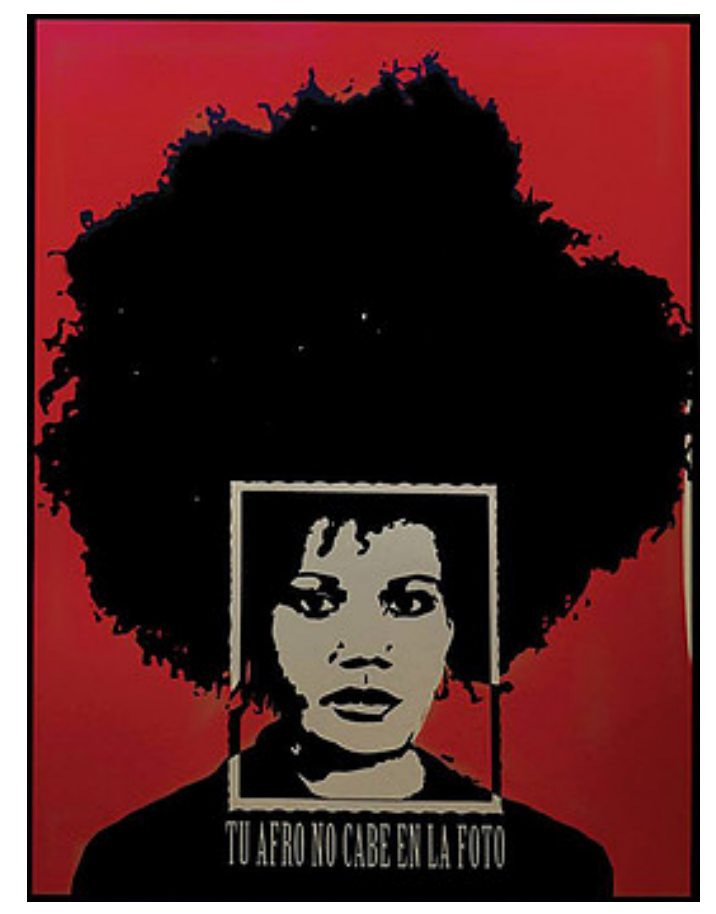

Figure 6 Alex Guerrero. Tu afro no cabe en la foto, 2015 Screen print. 22" x 30". http://www.laluchaoneisland.com/alex-guerrero?lightbox=dataItem-iq863e3v, accessed September 28.

In this chapter, I examine the radical potential of the afro in the contemporary Dominican space, given the ways that Afro-textured hair is coded as Haitian in the 
Dominican Republic. To that end, I examine how the afro destabilizes the boundaries between blackness and the ideal citizen with attention to whether and how the afro can be read as embodied resistance. Given the virtual absence of an anti-racist, Black social movement in the Dominican Republic (see Simmons 2009), the natural hair movement offers the opportunity to explore how the efforts of ordinary Dominicans to navigate blackness may create spaces for Haitian belonging. An examination of the natural hair movement acts as a bridge, linking the concerns of Dominico-Haitian activists with those of other groups who promote Black identity.

\section{Race, Beauty, and Hair}

Mary Douglas's Natural Symbols (1970[1996]) is the primary anthropological text to situate the body as a socially determined site where cultural meanings can be read. Douglas argues that bodily presentations communicate symbols which are "restricted by the demands of the social system" (76) reflecting sites of social struggle. Pierre Bourdieu (1979[2010]) applied this approach to the study of class, developing the concept of habitus to index the ways class identity is embodied including aesthetic choice, posture, and mannerisms. Michel Foucault's development of the concept of biopower (1979) situates bodies not just as sites to be read, but as key agents in the execution of the governmentality of populations.

Approaches to beauty cultures, relevant to the present analysis, have drawn on the concept of biopower to examine how female bodies are disciplined and women often make extreme efforts at "self-improvement" to meet beauty norms (Bordo 1993; Nichter and Nichter 1991; Wolf 1991). Beauty ideals are tied to social functions such as work, 
reproduction, and the production of women's subordination. The central preoccupation of this literature is the location of agency in women's beauty cultures. Therefore, these works make practices of resistance and refusal more visible than in Foucault's original articulation of biopower, insisting that women employ embodied strategies in ways that challenge and derive benefit from dominant systems of power.

Scholarship on beauty pageants return to the question of governmentality, focusing on the judgment and performance of beauty as a public spectacle. Pageants are civic events where elites crown queens who represent the "ideal female citizen," conforming to race and gender standards (Banet-Weiser 1999; Craig 2002; Rahier 1998). At the same time, they increasingly are avenues for women to stake a claim to civic life through the public communication of career and public aspirations (Banet-Weiser 1999) and can be a critical tool for communicating new racial, national, ethnic, and gender aspirations. This work has documented that beauty ideals are indispensable to the national imaginary by offering public displays to which citizens can aspire.

Black feminist scholars have made significant contributions to this scholarship, particularly emphasizing racialized aesthetics. Focusing on physical attributes such as hair, shade, nose and body shape, they have sought to locate the origins and effects of a beauty ideal that preclude Black bodies. As in earlier work on women and beauty, this literature has gradually moved from an examination of the ways that Black women reproduce and internalize their domination by ascribing to these ideals and are making efforts to recognize and make visible distinct modes of agency (see Banks 2000; Mercer 1987; Tate 2009).

The work on hair in the Black community has followed this pattern of moving its focus from internalized oppression to a more attentive examination of hair as it reflects 
domination and resistance. Hair straightening practices date back to slavery, when women used oils and plant resins to modify the texture of their hair (de Sá Dias et al. 2007, 2). Black communities in the the Americas and Europe still designate hair as "good" and "bad" and have high rates of hair straightening and relaxation. Alongside shade, skin color, and nose shape, these works have examined the racist origins and negative effects of "good hair" and "bad hair" designations (Collins 1990[2009]; hooks 1993). Efforts to depsychologize choices over haircare have placed more emphasis on how women navigate embodied strategies of accommodation and resistance. Therefore, this work rejects the unproductive line of questioning that places the burden of representation on women by claiming that hair straightening is a manifestation of self-hatred and portrays women as acting on the knowledge of a system that values whiteness. Instead, scholars evaluate these choices in the context of a multitude of strategies, some aimed at self-care and others at navigating racially hostile environments such as the workplace.

Kobena Mercer (1987) argues that hair straightening must be understood as historically situated. Straightening practices took on new connotations after the rise of the afro during the 1960s. In the "post-liberated" era of hair that succeeded the afro, Black hairstyling cannot be read as a mimicry of the White cultural form (which has been dethroned with the validation of the Black aesthetic) but should be seen "as creative responses to the experience of oppression and dispassion" (34) that include a variety of elements to form "new configurations of cultural expression" (51). Three decades after the publication of "Black hair/style politics," hair straightening continues to be popular among African diaspora communities as one option among a repertoire of "authentic" African American styles (Banks 2000; Tate 2009). As women of color whose bodies are regulated 
from all sides, choice becomes empowering whether between straight or natural styles (Banks 2000, 74). Therefore, "authentic" Black hair culture is an inherently hybrid culture that embraces mixture.

Natural hair has received far less attention beyond the 1960s/1970s Black power politics of the afro (Weekes 1997). Once a potent symbol of rejection of White supremacy, the afro has since become a fashion, devoid of any real connection to revolutionary politics (Davis 1994; Morrison 2006; Walker 2000). The contemporary revival of natural hair in the United States appears to follow the trend toward commercialization over politics (Byrd and Tharps 2014).

Previous discussions of Dominican hair have all addressed the relationship between hair and the acceptance/denial of blackness. The most thorough of these is Gerald Murray and Marina Ortiz's 2012 study of the role of the salon in Dominican culture. This investigation challenges what the authors see as a discourse demonizing Dominican racism, identifying several myths within the existing scholarship that uncritically denigrate Dominican racial formations. Further, they disavow the role of racism in promoting desire for straight hair, arguing that the popularity of hair straightening is due to its ability to make hair more manageable.

While Ginetta Candelario's 2007 study dwelt on the Dominican diaspora in the US, it can be extended to the relationship between race and beauty in Dominican culture. Candelario's work focused less on the actual practices of haircare and more broadly on racial aesthetics and attitudes among the workers and customers of the establishment where she conducted her fieldwork in New York City. She challenges the tendency to evaluate Dominican racial configurations within a Black/White binary found in the US, supplanting 
the binary for a tripartite model that privileges a mixed-race aesthetic. Dominicans, she argues, do not simply mimic a European racial aesthetic, but adopt the national racial construction of mestizaje. This assertion adds complexity to Cassandra Badillo's (2001) short discussion of natural hair. Badillo also challenges the idea that hair straightening changes one's racial identity, insisting that its major function is to signal acceptance of a system of white supremacy. To this date, no scholarship has seriously considered the potential role of the natural hair movement to pose a challenge to a racialized aesthetic that devalues blackness.

Social science research on beauty, and especially hair, provides ample evidence that bodily aesthetics can both reflect and resist domination. Women's bodies are enmeshed in discourses of power articulated through bodily aesthetics, given the Cartesian division of women into the realm of the body and men into the realm of the mind. Beyond gender relations, the representations of women's bodies are implicated in the construction of the ideal citizen, which is also classed and raced. Few have studied the significance of hair in determining racial/social hierarchies in the Dominican Republic. However, the scholarship based on US and British contexts provides a useful starting point for considering agency in Dominican haircare practices that emanate from within distinct racial classification systems. Further, at a historical juncture where citizenship is being redefined and reexamined in the public sphere due to the publicized policies regarding Dominicans of Haitian descent, challenging the dominant racialized aesthetic in the Dominican Republic carries with it the potential to challenge exclusionary nationalism. 


\section{“They Say Dominicans Do the Best Hair": Straightening as Slavery}

In her seminal book on Dominican racial identity, Candelario (2007) argues that hair texture, not skin color, is the primary racial identifier in the Dominican Republic. She is not alone in arguing that hair is a palimpsest on which society's racial ideologies can be read. Hair is often privileged in everyday conversations about blackness because hair is "the most tangible sign of racial difference" (Mercer 2013, 101). Unlike skin color, hair texture is more readily manipulated, making it a powerful tool for examining the effects of racial ideologies. Murray and Ortiz (2012) describe Dominican society as a pelocracia (literally, a government based on hair), given the central role of hair in determining social position and the declining importance of skin color (9). Their 2012 study on hair salons found that their numbers rival that of colmados, the ubiquitous Dominican corner stores, with only 10,000 fewer beauty salons, totaling around 55,000 establishments with 150,000 employees. There are no available statistics on the prevalence of hair straightening in the Dominican Republic, but it is a widespread global phenomenon. An estimated 80 percent of African American women have chemically straightened their hair at some point, along with 49.2 percent of black women in Cape Town, South Africa. In a 2007 study, 59 percent of African American women had relaxed hair (Aryiku et al. 2015, 1692). At an event about the politics of natural hair in Santo Domingo, one woman who spoke estimated that “98.99999... percent” of Dominican women straighten their hair.

Haircare is also an important economic factor in the lives of Dominican women. Women spend between 10 and 12 percent of their gross income on haircare. Those who earn more, invest more in these services and products (Murray and Ortiz 2012). A Listín Diario article published in 1998 and cited in Candelario (2012) claimed that women spent 
up to 30 percent of their income on haircare services (185). Women who wear straightened or relaxed hair, or hair with extensions, can spend anywhere between \$30 and \$80 USD per month, depending on whether they purchase their own products and the frequency of their visits, which can be up to twice a week (Murray and Ortiz 2012). These services are not limited to the wealthy sectors, but women at all socioeconomic levels are expected to visit the salon to cultivate socially accepted hair styles. It is a common practice that women rely on a romantic partner to pay for costly salon services (Saunders 2013), given that only half of all Dominican women participate in the paid labor force (Lugo 2012).

Salon visits also require a significant investment of time. It is common for women to form queues at salons at 9 AM, most of which do not accept appointments, and not leave the salon until the late afternoon. The day before a major holiday or on the weekend is especially busy with waits extending up to four hours and treatments lasting a minimum of two hours for a wash, setting in rollers, and blow dry. Straight hair styles are typically accomplished by applying chemicals or heat, both of which can be painful and traumatic processes. This is especially true for young women whose first experience with hair straightening is often for a special occasion, such as a communion or primary school graduation, instilling in them the idea that natural hairstyles are inappropriate in such venues. The salon plays such an integral role in women's lives that most never wash their hair at home, given the difficulties of reproducing "aesthetically acceptable" styles without the aid of an expert (Murray and Ortiz 2012, 116).

Many women are enculturated into this beauty culture that emphasizes straight hair at a young age. bell hook's (1993) narrative of her experience with hair straightening as a child shows it as a social practice that, while both painful and traumatic, facilitates bonding 
and sharing between generations of women. Although some Dominicans have naturally straight hair, it appeared as if most didn't. Beyond my own observations, during intermittent rains, strangers and friends were often concerned about my naturally straight hair getting wet, assuming that it had been blow-dryed straight. In another instance, at a community event in Los Mina, three young girls from 7-9 years old were especially curious about my hair and one girl cautiously stroked it. Some Dominican girls begin hair straightening as early as four (Rodríguez G. 2007), often for a special occasion, cementing straightened hair's hold on idealized standards of beauty. However, young women's hair is less closely regulated and Minerva, an interdisciplinary artist in her early 30 s, told me that as a girl, she was not conscious of her hair, despite being the only member of her family with curls. Later in life, her decision to wear her hair natural posed professional and educational barriers.

The thermal and chemical methods of straightening are both damaging to hair. With the thermal method, an oil protectant is first applied and the hair is brushed and blow-dried straight, often set in large curlers and dried under a hood dryer or passed through an electric flat iron. Chemical methods, often called relaxers, cause more permanent damage to hair as they employ alkaline agents to penetrate and break down the keratin complex in the hair shaft (de Sá Dias 2007, 4). The application of these chemicals is frequently painful, causing a burning sensation on the scalp. If used improperly, they can cause permanent scarring to the skin. Regular hair straightening carries several other medical consequences and has been linked to long-term hair loss, dandruff, and alopecia (Aryiku et al. 2015, 1694). Given the potential dangers associated with these substances, women are obligated to seek professional services. For critics of hair straightening, evidence of its damaging effects 
bolsters their claims that women are victims. Eva, a Reconoci.do member, describes the multiple burdens of hair straightening:

Después de que yo terminé el bachillerato y mi graduación, fui y mi desricé y dije a poco no vuelvo. Veo que cuando yo me lavo la cabeza y veo que mi crecimiento sigue igualito. Entonces pa' tu desrizarte ... tanto dinero ... y el tiempo que tú pasas, y el dolor de cabeza que te da, y ya, en los quince días tú tienes que volver. Es una esclavitud.

After I finished high school and my graduation, I went and I straightened my hair and I said, I won't come for a bit. I see that when I wash my hair and I see that my growth comes out the same. So, for you to straighten ... so much money ... and the time it takes, and the headache that it gives you and, fifteen day later you have to go back. That's slavery. ${ }^{32}$

Slavery is a useful metaphor that captures the relationship between the exacting pressures of hair straightening and a White supremacist racial order. This statement places these practices firmly within a system of racial oppression, invalidating interpretations of hair straightening that place the practice outside of dominant White supremacist structures and consequently pathologizing women who partake in the practice.

When not in the salon, women with straightened hair take steps to maintain the style, sporting tubis and satin head wraps to prevent disturbing their hair and to preserve its natural oils. Women who manage their haircare at home or in a friend's house, a minority, often wear their hair piled on their head in rolos (curlers) to help set their straightened styles. During the Dominican summers, a concern is the frequent Caribbean downpours that threaten to undo straight hair dos. Unexpected showers often force women to run for cover, wrap their heads in plastic, and be trapped inside to avoid another trip to the salon. These measures to protect straightened hair are not only economic

${ }^{32}$ Author's interview in Santo Domingo, March 20, 2016. 
considerations, but reflect the fear women have of appearing in public with their natural hair textures.

A popular saying warns male suitors that they should not marry a woman before taking her to the beach (Murray and Ortiz 2012, 2) because when in contact with water, straightened hair regains most of its former structure. This anecdote contributes to social pressures to "marry well," with appropriate partners resulting in potentially lighter skinned children. It also suggests that women straighten their hair to deceive others by occupying a higher social position than that to which they would otherwise be relegated. Further, this anecdote suggests that hair is an important factor in the selection of potential partners. One natural hair blogger shared a story in which she canceled a date because she could not get an appointment at the salon in time. "I panicked thinking that he would know my real hair," she wrote (Féliz 2014).

Women's fears extend beyond the potential loss of a romantic partner to include the fear of violence. Natural hair often carries racialized connotations of poverty, as mentioned above, and rebelliousness. In the Dominican context, blackness, and natural hair in particular, communicate immorality, indecency, and criminality. Beauty itself "remain[s] deeply enmeshed in questions of morality" and the refusal to meet beauty ideals represents an "aesthetic danger" (Brand 2000, xiv). In a 2007 article in Diario Libre, the popular roots singer Xiomara Fortuna reported that she no longer used public transportation due to the constant harassment she was subjected to: Me preguntan si acabo de salir de prisión. La gente simplemente no quiere que se vea esa imagen ("They ask me if I was just released from prison. People simply don't want to see that image") (Diario Libre, 13 June, 2007). Unlike Fortuna, whose middle-class position allows her to avoid the social stigma 
women experience because of their hair choices, most Dominican women cannot afford to avoid such public spaces where they may encounter verbal or physical violence.

During the discussion after an event on the history of natural hair in Santo Domingo, a young woman said she was assumed to be muy ligera, "very loose," and was subject to frequent harassment by men in the street. Carmen, a local independent journalist and activist, told me:

Tener el pelo natural es como tú estas mala... Hay hombres que le' gustan a las mujeres que tienen el pelo natural por el mito que viene desde siglos que utiliza a la mujer negra como una mujer de uso. A mí me han dicho: “¡Ay! ¡Ese cabello! ¡Yo te quiero agarrar!” A mí me lo dicen.

Having natural hair is like being bad...There are men who like women who have natural hair for the centuries old myth that utilizes the woman as a woman to be used. They have said to me, "Ay! That hair! I want to grab you!” They say that to me. $^{33}$

Carmen's reference to a centuries-old myth: the colonial dichotomy between White women's purity and Black women constructed as "immodest and as exuding an animal sensuality" (Tate 2007, 301), an extension of slave-era relations where Black women's bodies were considered the property of white men. These associations are exacerbated for women who are already criminalized or discriminated against for their Haitian ancestry.

\section{Men's Hair}

In patriarchal society, women's beauty standards are more restrictive than men's. However, men in the Dominican context are expected to maintain short hair, considered as more professional. Men pay significantly less for professional haircare, about $\$ 8$ US for

${ }^{33}$ Author's interview Santo Domingo, April 10, 2016. 
these services, including a shave and visit to the barber bi-weekly, depending on their rate of growth. Men with straight, wavy hair and loose curls have more freedom to wear their hair a bit longer. Carmen became especially interested in the racial implications of men's hair after a college professor reprimanded her college-aged son and demanded that he cut his hair: y no solamente a él, a todos los muchachos que tienen trenzas, se las mandó a cortar ("and not just him, to all the boys who have braids, she sent them to get a haircut.") During our interview, she pulled out her notebook to read a quote she had recorded from a young classmate of hers. When she asked him why he kept his hair so short, he claimed that the style cleared his face. He went on to clarify: La frente se me ve muy negra cuando tengo el pelo largo, y no es que me avergüenza el color ("My forehead looks very Black when my hair is long, and it's not that I'm ashamed of my color.") The youth's comments highlight the relationship between hair and perceptions of color, while they reject an interpretation that he is practicing self-hatred.

Carmen was struck by the way he disavowed the connection between his hair choices and race. However, this young man's experience is not uncommon. Often, choices about bodily presentation and care are not considered to be political. Many women whom I spoke to did not see their preferences as having any significance beyond their own personal inclinations. They especially did not see the role of race in these choices. Therefore, they allow for a different relationship toward blackness to be formed by appreciating and valuing Black hair while not focusing on a politics of identity. While as a political strategy, it runs the danger of depoliticizing the Black body, it also has the potential to undermine the Dominican system of racial classification. Hair also presents an irrefutable, undeniable truth of remaining connections to blackness, despite genealogical 
and nationalist revisions that try to place blackness securely in the past or abroad. It also offers a point of identification between Haitians and Dominicans across national and ethnic barriers, although much work remains to be done here.

Boys and men with longer Afro-textured hair often face harassment by the police. An activist living in a marginalized barrio in the national district reported that there, young men with these hairstyles were regularly identified as criminals and thieves, and arrested. David, who was visiting his mother after moving abroad, told me that he was arrested thirteen times for various crimes he did not commit because his dark skin and short dreads were associated with criminality. On one occasion, David recalled, he was threatened with deportation because authorities accused him of being Haitian, linking pelo malo to Haitians. Authorities requested that he accurately roll his $r s$ before releasing him.

These moral connotations are pronounced in the categorization of hair as pelo bueno (good hair) or pelo malo (bad hair). In her analysis of the same terms, Candelario (2007) defines these terms, writing, "There are clearly racial connotations to each category: the notion of pelo malo implies an outright denigration of African-origin hair textures, while pelo bueno exalts European, Asian, and indigenous-origin hair textures" (182). Murray and Ortiz (2012) define pelo malo as "the curly hair characteristic of individuals of African descent" and pelo bueno as "straight hair, inheritance of not only Caucasians that brought those as slaves, but also other genotypes, including Asians and the already decimated Taíno Indians" (4). Murray and Ortiz use this latter definition to argue that straight hair is not an aesthetic tied to whiteness alone but represents a wide spectrum that includes, but is not exclusive to, North America and Europe. They extend Candelario's argument that Dominicans demonstrate a strong preference for a mixed-race aesthetic 
beyond a White/Black binary. However, they fail to examine the societal demands that require straight hair styles to navigate everyday life in the Dominican Republic. Pelo malo/pelo bueno represents the dominant narrative around hair straightening practices on the island that divorces them from questions of race and power. Natural hair advocates, however, are working to challenge this discourse.

\section{Institutionalizing Straight Hair}

Dominican media continues to play a significant role in privileging straight hair and light skin. In 2013, Yaritza Reyes, who competes with natural hair and openly celebrates her African heritage, won the Miss Dominican Republic beauty contest. Before her crowning, few television shows or magazines featured women who did not have straight hair - either natural or processed. In recent years, beauty magazines, films, and commercials have increasingly featured dark-skinned women with abundant curls. Yaritza played a supporting role in a popular Dominican comedy film, Tubérculo Gourmet (2015), alongside a natural-haired actress who played her sister.

Although natural hair is increasingly represented in popular media from the $L a$ Sirena department store catalog to Banco Popular commercials, traditional African hairstyles and textures remain taboo in public offices, places of employment, and schools. Such hairstyles are deemed inappropriate and unprofessional, especially for women working in white-collar occupations. Therefore, those who do not abide by normative expectations of beauty suffer very real consequences that block their access to public services and the material benefits they provide. Despite having signed various international 
accords aimed at eliminating racial discrimination, Dominican public and private institutions are rarely held accountable for these widespread practices of discrimination.

Often, schools and employers utilize policies such as a dress code and the concept of buena presencia (literally, "presentability") to justify the exclusion of Afro-descendant people from work and educational spaces. Feminized service positions in tourism or customer support frequently place more scrutiny on women's appearance. In an article on the nature of discrimination in the Dominican Republic, one interviewee observed, "most of the secretaries and receptionists are white" (Rumbo 1995, 10). A female student supported this claim highlighting how buena presencia is used to exclude racially undesirable applicants from certain economic sectors:

Hay áreas ... como la comunicación, los servicios a clientes, el turismo y otras áreas comerciales, donde el prejuicio tiene más peso porque las empresas buscan por lo regular personas con "buena presencia," entendiéndose por buena presencia que tenga la tez clara, rasgos caucásicos y pelo lacio, nunca rizo. Creo que las mujeres lo sentimos mucho más porque con los hombres la sociedad es más benévola en ese sentido.

There are areas ... like communication, customer service, tourism and other commercial sectors where prejudice has more weight because the businesses regularly look for people with "good presence", understanding that for good presence one must have light skin, Caucasian features, and straight hair, never curly. I believe the women feel it much more because with men, society is more benevolent in that sense (Rumbo 1995, 10).

In her work among Brazilians and Puerto Ricans in New Jersey, Ana Y. Ramos-Zayas (2012) suggests that the practices of "self-care" implicit in the requirement that employees embody "good presence" should be viewed as more than vanity or luxury, but "among young women of color, these were also aspects of "upkeeping" that were central to getting a job" (220). As public positions in customer-facing professional and administrative 
sectors, positions that are often occupied by women, the racialized aesthetics of these fields are highly scrutinized. Employment in the service industry offers a means of class mobility for women with little experience and education. As the service and tourism sector expand, barring women of color from these positions is increasingly detrimental to their economic futures.

In a 2013 television interview on the program Ser Humano, five women recalled experiences of discrimination on the streets and in the workplace. When offered employment at a company, a woman featured on the program was told that she had to straighten her hair to work for the marketing company. Unemployed at the time, she reluctantly straightened her hair after one year of abstaining from straighteners. The company never contacted her again and after having several unsuccessful job interviews, she began to suspect that she was not being hired because of her natural hair (Ser HumanoTV 2013). Most women, however, only suspect that obstacles to finding employment are due to their natural hair because they are never told expressly that it is the reason they were not hired.

\section{Education}

"En nuestras escuelas, tú no puedes ir con el pelo afro. En nuestras instituciones tú no puedes estar con el pelo afro. Si es no es racismo, ¿qué diablo es?” (“In our schools you can't attend with afro-hair. In our institutions, you can't be there with afro-hair. If that's not racism, what devil is it?) Rafael, a young Dominican rapper whom I met performing at an event about racism, posed this rhetorical question. He wore his hair in long dreadlocks that almost reached his waist. Rafael articulated the difficulty of talking 
about racial issues in Dominican society. Many Dominicans deny the existence of racism in the country, reasoning that there is no systematic effort to segregate and oppress darkerskinned Dominicans. While acknowledging the existence of prejudice, the Dominican Republic comes out ahead when compared to the United States as legal race-based regulations have been uncommon in the Caribbean country. However, the recent visibility of cases barring children from school for wearing natural hair has led some to question the role of public institutions in promoting racism. In addition, the racial implications of $l a$ sentencia 168-13-discussed before-has raised troubling legal questions about the racialized mistreatment of Haitian immigrants and their descendants.

Young women experience discrimination at all educational levels where they are shut out of classes and exams for their hair. Rosa, a young college student who was not of Haitian descent but considered herself an ally, recalled her struggles to wear her hair in natural styles at multiple points in her high school career. In her second year of high school, the director and the psychologist urged her to change her natural hair style:

no fue permitido mi pajón porque no era lacio ni estaba recogido. Entonces, cuando yo estaba en tercero, de bachiller, yo aún así, llevaba las trenzas. En primer lugar, me botaron, a mí me dejaron fuera [del aula] ... y yo le dije que no me podían sacar de la escuela por mi forma de peinado y la directora dijo que había una circular del Ministerio de Educación que prohibía ese tipo de peinado en los centros educativos ... Cuando yo le solicité a ella que por favor me dejara leer la circular delMinisterio de Educación ella me dijo que no.

my afro wasn't permitted because it was neither straight or gathered. So, when I was in my third year, of high school, I was still like that, I wore braids. In the first place, they kicked me out and left me outside [of the classroom] ... and I told her that they couldn't take me out of school because of my hairstyle and the director said that there was a memo from the Ministry of Education that prohibited that type 
of hair in the educational centers ... When I asked that she please let me read the memo from the Ministry of Education, she told me no. ${ }^{34}$

Without evidence of an official policy, school authorities repeatedly pressured Rosa to change her hair. Further, the director's justification of the rule by citing the Ministry of Education as the source of the policy intended to impress on Rosa that her hair was not only deemed inappropriate by the individuals at her school, but at the level of the state. Rosa attributed her ability to stand up for her rights to her parents, who always instilled her with self-confidence.

At the university level, Alicia, a Dominican of Haitian descent who struggled for years to secure the proper documentation to study, recalled that on the second day of Spanish class, she was so humiliated by the professor for her braided hair that she unenrolled from the course. In front of more than 50 of her classmates, the professor told her, Te ves tan ridícula con ese cabello. ¡Pero qué fea! ¡Qué ridícula! ... Eso te queda muy ridiculo. Tú te ves muy fea. ("You look so ridiculous with that hair. But how ugly! How ridiculous! That looks ridiculous on you. You look very ugly." $)^{35}$ Alicia responded by saying, Si no le gusta mi cabello eso es problema suyo, eso no es problema mío. Lo importante es que yo me sienta bien con ello. ("If you don't like my hair that's your problem, it's not my problem. What's important is that I feel good about it.") Although she defended herself in that moment, asserting that her hair style was more than about beauty validated by outsiders, but about a personal pride and confidence, Alicia could not return to the class that she had worked so hard to enroll in. She assumed that she could never get

\footnotetext{
${ }^{34}$ Interview in Santo Domingo, March 9, 2016.

${ }^{35}$ Interview in Santo Domingo, March 16, 2016.
} 
a fair grade from a professor who would make these remarks. Alicia never reported the incident to the school administration, reasoning that it would just brush it off. If someone had attacked her physically, she explained, there would be a response, but the institution regularly dismissed verbal attacks such as the one she experienced.

Recalling her own experiences at work and in school, Minerva reflected that she never had issues with her abundant, curly hair before she experienced discrimination within these institutions. Although she visited the salon at times, she did not feel that straightening her hair was obligatory. She considered it one among a variety of styles she could adopt at any time. Although her family accepted her preference, once she enrolled in an elite Catholic school she ran into problems and was prevented from attending classes until she straightened her hair. She describes that episode in her life as muy violento ("very violent"), and realized that realmente, ese pelo significaba algo ("really, that hair meant something.") Later in life, at a job in a prominent art museum, she was told that her form of dress was inappropriate. Minerva knew that this meant her hair, finding that her dress conformed with the code she was given. She was fired shortly after that and although she was never told it was because of her hair, she continues to suspect that was the reason.

Hairstyle is especially important in regulating labor and education because it communicates obedience to the dominant norms of society. Failing to straighten one's Afro-textured hair signals resistance and rebelliousness, traits not desired in the highly structured settings of the school and workplace. More than communicate the racial desires of its wearer, "in order to find a job and/or acceptance in social circles, circles that in some manner exert authoritarian control, women need to show their submission and acceptance" (Badillo 2001, 38). Therefore, Badillo argues, straightening often represents one's 
willingness to stand down to racial and gender-based oppression and accept racial hierarchies as valid, if not natural. Moreover, the experiences of the women related above demonstrate how public and private institutions police natural hair. The preoccupation over natural hair further demonstrates its potential to challenge existing power relations because women's rejecting such racialized beauty standards poses a challenge to both racial and patriarchal sources of oppression. Although the experiences of the women related here focus on those who challenge discriminatory practices, they reveal the difficult social and economic conditions that structure women's haircare choices in the Dominican Republic.

\section{Roots of Resistance}

In July 2016, protests erupted over the discriminatory comments of the Minister of Higher Education in Science and Technology to a student whom she reportedly told, no le doy becas a personas que tengan pelo como tú ... Soy anticuada ("I don’t give scholarships to people like you ... I'm old-fashioned." $)^{36}$ As a government employee charged with judging the suitability of students to represent the nation abroad, the minister may have felt that the woman's natural hair would incite a negative perception of the country, given that those bearing such hairstyles are considered less intelligent and unprofessional in the Dominican Republic. The scholarship sought by the student was for study in Spain. Perhaps, given the foundation of Dominican culture in Hispanicism, sending a naturalhaired representative of the nation to the "Mother Country" would undermine the state's

\footnotetext{
${ }^{36}$ Account by student Fátima González Méndez (Nicky) reported in a letter drafted by activists sent via email communication August 8, 2016.
} 
practice of distancing itself from blackness. Furthermore, the minister's classification of her position as anticuada both situates her attitude within a long tradition of resistance to Afro-diasporic visibility in the public sphere and acknowledges the modernizing impulse that has ushered in the recent transformations in Black aesthetic practices and identity.

What originated as a Facebook post describing the incident Nicky González wrote, so that quede constancia que ella es una racista ("there is a record that she is a racist"), benefited from the support of a growing coalition of activists and individuals organized around the issue of natural hair. Within days, the post was shared over 5,000 times and received over 7,000 "likes" by those supporting the political science student. A small group of protesters, mostly women representing a variety of skin colors from light to darkskinned, gathered outside the Ministry of Education's offices on August 11, 2016 and chanted:

Tenga cuidado que en esta isla, ya no podemos seguir siéndonos racistas. Tu herencia afro hoy reivindica, saca e' tu mente el fascista que te habita. Sal a la calle, ponte la' pila' y la violencia no dejes que se repita.

Be careful because on this island, we can no longer remain racists. Your African heritage demands today, rid your mind of the fascist that inhabits you. Go out in the street, get animated, and don't let the violence repeat itself.

Several of those in attendance were members of various social movements in the country with representatives from organizations focusing on labor, feminist, and Haitian diaspora issues.

A letter cataloging the demands of the protestors addressed to the minister, her immediate supervisor, and the president sought that educational curriculum be revised to prevent future generations from reproducing the same racist system. Twenty-six 
organizations and 186 citizens signed in support of the complaint, which called for the inclusion of an anti-racist perspective, critical perspectives on colonialism, the visibilization of the struggles of Afro-descendants and maroons, and more diverse representations in textbooks, reflecting the diversidad del fenotipo dominicano ("the diversity of the Dominican phenotype.") The letter argued that the educational system itself was responsible for perpetuating racism.

The letter also links these discriminatory practices to the practice of barring undocumented children, mostly poor, Black, and of Haitian descent, from public schools, thereby linking codes of dress and appearance to broader systems of racism and xenophobia. Many of the interviewees' experiences recounted in this chapter affirm the connections between natural hair and anti-Haitian stigma, suggesting that the widespread adoption of natural hair may help destabilize the divisions between Dominicans and Haitians and the associations among blackness, savagery, and criminality. Furthermore, racism is framed here not as an individual, but as a structural and institutional problem. The broad connections that these protesters make between the rejection of a cultural politics of Black hair and anti-Haitian policies demonstrate the potential of these issues to mobilize and represent a broad coalition of activists around race, gender, ethnic, and migration issues.

\section{The Dominican Natural Hair Movement}

What exactly constitutes natural hair is unclear. While it is sometimes used exclusively to describe hair that is free of all chemicals and dyes, more broadly it is used for hair that is free of chemical relaxers or any process that alters the texture of the hair. 
Therefore, many experiment with color, chemically derived, and synthetic hair. The growth of the natural hair movement is noted in a footnote in Murray and Ortiz's Pelo malo/pelo

bueno:

Existe en el país una corriente de mujeres de pelo muy rizo que lo lleva orgullosamente "natural" (así entre comillas, pues para que luzca "hermosamente nautral" deben ponerse tratamientos especiales que muchas veces solo pueden obtener en el salon). La mujer que lleva el pelo rizo suele ser de clase media alta, segura de sí misma, con cierto nivel educativo y de ideas socio-políticas liberales, y muchas veces con sentido artistico. (Hay otros casos en que se trata de simple pereza o falta de dinero) .... Sin embargo, representa una corriente minoritaria dentreo de una cultura estética que valorize, casi de manera dictorial, el pelo lacio.

In the country, there is a trend of women with very curly hair who wear it very proudly "natural" (in quotes, because to look "beautifully natural" they should use special treatments that much of the time they can only get in the salon). The woman who has curly hair is usually from the upper-middle class, sure of herself, with a certain level of education and liberal socio-political ideas, and much of the time with an artistic side. (There are other cases in which it is simply a matter of laziness or lack of money) .... In any case, it represents a minority faction within an aesthetic culture that valorizes, almost in a dictatorial manner, straight hair $(2012,10)$.

Despite Murray and Ortiz's dismissive tone when describing the natural hair community, since the completion of their study, the natural hair movement has rapidly expanded. The year 2012 saw the aperture of the first hair salon in Santo Domingo dedicated solely to natural hair, Go Natural Caribe (Grassals 2014), with a second natural-hair salon, Miss Rizos, opening in 2014 and moving into a bigger location in 2016. At least every other month, local members of the natural hair movement, largely entrepreneurs, organize public gatherings in the capital.

During the natural hair events I attended in Santo Domingo and the surrounding area, the demographics of the attendees confirmed Murray and Ortiz's characterization of the constituency of the movement. Women I spoke to worked in liberal politics, media, and 
medicine, among other middle and upper-middle class professions. While many of their activities involved the promotion and sale of products, they also served as networking and social opportunities.

These events provide important spaces for women who face the types of institutional discrimination described above, along with harassment by strangers and family members alike. For women in the Dominican Republic, as in many other places, gratuitous comments about their appearance are almost ubiquitous. In my interviews with women who wore their hair natural, every single one recounted experiences of harassment, either in the street, in the salon, or within their families. Women were regularly called loca, haitiana, greñuda, and escoba (literally, crazy, Haitian, hairy, and broom), among other derogatory names. As Carolina said in her SerHumano TV appearance, Yo caminando en la calle, la gente me mira y me llama "haitiana," y para mí, no me importa que me llamen así pero sé que lo hacen con una intención de ofenderme ("When I walk down the street, people look at me and they call me 'Haitian,'and, for me, it doesn't matter but I know they do it with the intention of offending me.") Therefore, Carolina makes clear her rejection of negative associations with Haitians.

When first deciding to stop straightening her hair, Eva went to the salon after five months of growth and the hairdresser assumed she had returned to desrizar (uncurl) it. Leaving with only a trim, she said that her decision to stop straightening surprised many. She traveled abroad shortly after and received many compliments on her hair. She welcomed the positive reactions, still sensitive about the way she looked. She explained, En mi país, no lo ven así (“in my country, they don't see it like that.") 
Bloggers describe "going natural" as a process whereby women must eliminate any hair that has been chemically altered and learn new approaches that do not significantly alter the hair's structure. Although many people have never chemically straightened their hair, bloggers generally assume that most going natural have hair that has been transformed and/or damaged by excessive application of these chemicals and/or heat, given the predominance of these practices. There are generally two different paths to "going natural": transition and el gran corte, or "big chop," both involving cutting off the hair that has been altered by straightening. However, those who opt for the "big chop" have not gone through a period of letting their hair grow out (without straightening) beforehand.

As indicated by the gerund tense in the phrase "going natural," it is framed as an ongoing process. Dominican Republic-based social media groups offering support to persons transitioning to natural hair document this process by posting updates at varying intervals of the style and length of members' hair three months, six months, and a year after adopting the natural hair style. Much like sobriety tokens in Alcoholics Anonymous, one's hair length and health offer evidence of one's daily struggle to resist the pressures to straighten. Thus, "going natural" is not a temporary decision, but a long-term and permanent process which marks a definitive break from "unnatural" hair, or as one hairdresser in a natural hair salon put it, el pelo que no te pertenece a ti, "the hair that doesn't belongs to you." She turned from the client she was working on and explained that if her client, who was dark-skinned with tightly coiled hair, exchanged her hair with my straight, fine hair, we would both look "wrong," suggesting that it would not match our phenotype. However, the distinction between "natural" and "unnatural" hair was far from an absolute dichotomy. Although naturalistas (naturalists) are expected to maintain a 
commitment to not straightening their hair, dyeing and adding extensions are generally accepted as forms of creativity and expression. "Natural" hair, therefore, was framed as communicating one's racial truth by not masking the hair as a marker of race.

In the face of the regular harassment and discrimination that women experience, entrepreneurs/activists have emerged to provide services and support for the growing natural hair community in the Dominican Republic. The most prominent and vocal speakers on this subject, like Carolina Contreras (Miss Rizos) and Evelin Guerrera (Quisqueya Natural), got their start through social media that offered practical advice for caring for natural hair, emotional support and guidance, and product reviews and endorsements. Two of these social media sites have converted their virtual following into full-service salons (Go Natural Caribe and Miss Rizos), both located in high-end sectors of the capital district. One of these salons was designed intentionally as a place to support women's choice to wear their hair in natural styles. The owner of one of these spaces is involved in training her staff and instructing guests to avoid negative and disrespectful comments, including a jar into which those caught using terms such as pelo malo, must pay a penalty. On her visit, Eva described the space as cozy, de uno mismo, "of one's self," given that the clientele who frequent these spaces tend to share similar aesthetic and political views.

When I inquired whether I could sit and observe in preparation for an interview with the proprietor, she denied my request. While I was welcome to partake in the salon's services, she explained, she did not want her clients, who have limited spaces to enjoy these services free of judgment and scrutiny, to feel as if they were being observed. Although I did not insist, I suspect that being a non-Dominican born with straight fine hair would 
exacerbate the issues the owner saw with my presence in the salon. Clients already lived in a context where images of a light-skinned Latina with straight hair were the norm they were constantly pressured to emulate.

Women's decisions to "go natural" vary by reason, including economic and health concerns. These reasons can transform over the process as events in women's lives change their meaning and needs from their hair and haircare regimen. In over 300 responses to the question posted on the Miss Rizos Facebook page (May 24, 2016), ¿Por qué regresaste a tu cabello natural? most women cited health concerns and lack of time to go to the salon as the top reasons why they returned to their natural hair. Less than 5 percent of the respondents cited racial pride or consciousness as a primary factor. This is not to say that race was not among the concerns that women expressed or that an individual's understanding of these practices could not change over time.

Eva's initial decision to stop straightening her hair was motivated by the financial burden of frequent salon visits and the detrimental health impact of the chemical straightening process. It was only later, as she increasingly became involved in social issues that she began to associate natural hair with racial identity: Ahora ya no la veo como una decisión económica pero una forma también de uno aceptarte como uno es. Mientra' yo iba viendo en cada reunión, cada cosa, la identidad de uno y lo cultural ..." ("Now I don't see it not as an economic decision but also as a form of accepting oneself as they are. At the same time, I was seeing in every meeting, everything, one's identity and the cultural ....") Therefore, in Eva's case, the physical and economic burden of haircare, alongside a growing consciousness gained through overtly political and cultural activities, led her to frame her haircare practices within the terms of racial pride. At an event on the politics of 
the afro, the consensus was that natural hair was only a significant act of resistance if it was worn by those with an awareness of its potential meaning. While most in the audience found the increased visibility of the style to be positive, it could not be categorized as revolutionary.

While Eva complained about the prohibitive pricing of natural hair salons, with the most affordable service at one salon costing $500 \operatorname{pesos}^{37}$ ( 11 USD), Eva admitted that as spaces designed to serve the natural hair community, salons offer a refuge from what is often a hostile public atmosphere for persons who maintain natural hair styles. Salons also serve as spaces in which women can confidently ask questions and seek advice about how to care for their Afro-textured hair, given the dominance of the straightening culture. Often excluded from traditional hair salons that promote straightening and relaxing treatments, events and spaces created specifically for those with natural hair offer important alternatives for socializing among women. Eva said that she regularly experienced negative comments in the salon, where customer and employees alike would openly talk about how "bad" and "hard" her hair was. More than its utilitarian function, the salon is a social space where women gather to talk about a wide range of topics and "reaffirm their personal worth beyond their roles as mothers, wives and lovers, and workers" (Candelario 2007, 208). Therefore, the salon can be a therapeutic space (Black 2006) where women are validated and make community. Natural hair salons work at providing an alternative space where women of color can continue to build these relationships without fear of rejection. This is particularly significant for Dominican women who are accustomed to visiting the salon

\footnotetext{
${ }^{37}$ Cost of a wash, deep treatment, and detoxification or twists at Miss Rizos Salon. Source: https://www.missrizos.com/el-salon/.
} 
frequently. Freedom from the burden of salons that straighten hair is one of the advantages touted by those who wear their hair unprocessed. In addition, social media sites offer virtual spaces for creating female-to-female relationships. I am aware of at least six groups based in the Dominican Republic and, as of 2014, the blog Miss Rizos claimed at least 40,000 followers. Eva admits that today, the popularity of natural hair makes the transition process easier than it was for her when she decided to "go natural" seven years earlier:

Ahora ... no sé si es por la moda dique del afro y eso, pero el tiempo en que yo dejé de desrizarme la gente me veía difícil. Todo el mundo se ponía a murmurar. Incluso, lo que no hacían que yo me desrizaba era de que darme dinero pa' ir a desrizarme. En el segundo día que yo no me desricé estaba todo el mundo, "Mira, yo te voy a dar tanto para que tú vayas y te desrice' ese pelo. Porque está muy feo."

Now ... I don't know if it's because the fashion of the afro as they say and all that, but at the time that I stopped straightening the people looked at me hard. Everyone began to whisper. Including what they hadn't done when I straightened my hair was they gave me money so that I would go straighten my hair. The second day that I didn't straighten the whole would was like, "Look, I'm going to give you this much [money] so that you can go and straighten your hair. Because it's ugly." 38

The social space and sense of community helped Eva through the years come to terms with her transition. Her pride in her appearance, one that visibilizes her African heritage, has also helped her claim her Haitian heritage with pride, and she claims to no longer feel offended by people tell her she looks Haitian, tengo que parecerme haitiana, "I have to look Haitian," she said, because her parents were born there. Here, Eva makes clear the connections that tether Haitianess, hair, and blackness.

Given the difficulties women face in school and the workplace when sporting unstraightened Afro-textured hair, it is no surprise that the natural hair movement is largely

\footnotetext{
${ }^{38}$ Interview in Santo Domingo, March 20, 2016.
} 
led by middle- and upper-class women who exercise significantly more economic options than lower-class women. The services at the salon are also pricier given that women frequent them far less than they do the traditional salons. A wash at a traditional salon costs around 150 pesos, about $\$ 3$ USD, and the most popular natural hair salon charges more than three times that much. Both Eva and Alicia complained about how expensive the salon services were and treated their visits to the natural hair salon as a rare, but special occasion.

Although many impoverished women cannot afford to straighten their hair, few understand their haircare choices as political as many women at the forefront of the natural hair movement. Instead, unstraightened hair is often a marker of poverty and women are frequently offered money by acquaintances and strangers who assume their decision not to straighten their hair is due to economic constraints. Similarly, due to the practice of racializing Haitians as Black and poor, those with natural hair were regularly called "Haitian" in the street, often used more as an attempt to insult than an effort to accurately identify them. During the incident with the professor, Alicia, a university student and Dominican of Haitian descent activist, was told that only haitianas de la orilla (a pejorative term for Haitians in the Dominican Republic) wore their hair in braids. Unsure as to exactly what this meant, Alicia speculated that the professor was referring to the most marginalized and poor Haitians. Alicia does consider natural hair to be part of Haitian culture, although many Dominican women adopt the style.

Although Alicia, Carmen, and Rosa all criticized the natural hair movement for being more concerned with fashion than politics, Eva only gained the confidence to wear natural styles after it had become popular to do so. The same reluctance she felt when revealing her Francophone last name was transferred to her hair, which also marked her as 
Haitian. She first began to straighten her hair at thirteen but began to feel the stigma of natural hair when she left the batey to move to the city. In the batey, it was common to see people with natural hair. Once in Santo Domingo, she realized that no one in the church or university she attended wore their hair in natural styles. Despite wanting to abstain from straightening, she thought, Si yo dejo de desrizarme, ¿cómo me voy a ver? Imagínate, yo, negra y pobrecita ... y no. ("If I stop straightening, how am I going to look? Imagine, me, Black and poor ... and no.”) They all perceived participation in the natural hair movement as requiring expensive treatments or attendance at gatherings in far or middle-class places such as Boca Chica or Mirador Sur. These were spaces less accessible to working class women.

\section{The Potential Politics of the Pajón}

One of the most prominent natural hair advocates in the Dominican Republic, Carolina Contreras, who has appeared in dozens of international and international venues including The New York Times, Al Jazeera, Latina, and Cosmopolitan, told one interviewer:

I feel so indebted to these kinks and curls for making it easier for me to talk about something that's often uncomfortable and intimidating to discuss. The truth is that many people don't want to hear about the Diaspora, being Black, Africa, etc. but if you can capture their attention through a conversation about hair, if you empower them by teaching them how to care for something they were taught to hate, then we can talk about our blackness and what that means (Dawson 2014).

Like the protesters who organized in support of Nicky Gónzalez, Carolina frames hair as a vehicle to move forward conversations about race and the African heritage. However, unlike the protesters, she rejects the method of public protests, chants, and slogans, finding 
them less effective means than the alternatives provided by hair care. In an interview at her salon, she argued:

it's an easier vehicle and channel to talk about these things because it's fun and because it's aesthetics initially and we're not like, it's not harsh, and it's not like in-your-face and I think that oftentimes when we do have those kinds of activisms like the "Black is beautiful" and "Black power," not to say that they weren't successful, they're not important in history and where we are now, but I feel like they're not necessarily the way to go now because I think that people shy away from those terms or from that approach. It's like saying Black is beautiful or saying Black power is like almost preaching to the choir. Usually the people who respond to that are people who are already empowered, people who already acknowledge that they're Black. You can't go into a community where people don't like blackness and be like "Yo, Black is beautiful" and they're like ... "Okay, I'm not Black, I'm not Black, what you talkin' about?" So, it's like oh, yo amo mi pajón or talk about curls and it just makes it a lot easier. ${ }^{39}$

Carolina's insistence that "Black is beautiful" is a less useful tool than a discourse about self-care and self-love stems from a recognition that the phrase has less to do with bodies and more about promoting Black consciousness. This philosophy intimates a sharp awareness, gained from experience as an activist, that the most effective means of resistance are embedded in daily life (Scott 1990). For Carolina and others in the natural hair movement, the materiality of the body made it more recognizable as a site that reflected society's anti-Black prejudice.

. The owner of the nation's first natural hair salon saw her role not as promoting natural hair as the only option but expanding women's choices. By not enforcing a rigid Black aesthetics, this iteration of the natural hair movement allows for the integration of blackness within dominant conceptions of mixed race identity (mestizaje) in the Dominican

\footnotetext{
${ }^{39}$ Interview in Santo Domingo, June 9, 2015.
} 
Republic. Therefore, it creates a space in which African inheritance is located in the body and is appreciated and nurtured:

hoy día ya sea por moda o por cambio de estilo de vida, mucha gente se ha abierto a la idea de llevar su cabello natural sin complejos y afortunadamente a la par se han diseñado productos para nuestro tipo de pelo que nos ayudan no solo a llevar el cabello natural, pero también a llevarlo de una manera hermosa y cuidado. Siento que las mujeres también estaban ya cansadas de solo tener la opción de llevar el cabello alaciado, pasando por todos los procesos que ofrece un salón convencional; ahora existen más posibilidades, ya sea que quieras arreglar el cabello en casa o que quieras ir a un salón donde sabes que la oferta no sólo se limita a químicos para alisar.

today whether it be fashion or change of lifestyle, many people have been open to the idea of wearing their natural hair unapologetic and fortunately alongside this they have designed products for our type of hair that help us not only to have natural hair, but also to wear it in a beautiful way and take care of it. I feel that women also were tired of only having the option of wearing the straightened hair, going through all the processes that a conventional salon offers, there are now more possibilities whether you want to fix your hair at home or you want to go to a salon where you know that the menu is not only limited to chemicals to straighten (personal communication March 30, 2015).

The salon owner asserts that expanded choices for women of color give them more control over how they represent their bodies. In her view, multiplying women's options is more empowering than merely replacing a White aesthetics with a Black aesthetics.

By activating a collective of people who share their stories of transition to natural hair, stories where discrimination and intolerance often play a significant role, this community reveals that widespread refusal of natural hair manifests the effects of racism made invisible by the ideology of racial democracy in the Dominican Republic. Burnt, brittle, dry hair, and scars from chemical burns wrought by the straightening process are tangible representations of the deleterious effects of beauty ideals that devalue Afrotextured hair. Some describe their break from the cycle of straightening as escaping 
enslavement to straightening their hair, referring to the frequent need to visit the salon and the disproportionate burden placed on Black women to submit to harmful and painful chemical processes. Alicia identified the prevalence of natural hair among Haitian communities as emerging from a stronger self-esteem among Haitians than among Dominicans. In Haiti, she speculated, you could go out with your natural hair and no one would say anything to you; no one would look at you strangely, pero aqui no, she said of the Dominican context. If you entered a space with your hair mal arreglado (in disarray), they would look at you up and down. That is why Dominican women are obligated to go to the salon, while Haitians are not, se arreglan en el patio, ("they do their hair on the patio"), she stated.

Inherent to the promotion of an aesthetics of the pajón is the necessary challenge to the dominance of the racialized ideal of pelo malo as it reinscribes this hair as worthy of the same types of nourishment and skilled care as straight hair. The politics of the pajón, celebrated in proportion with its size, the bigger the better, also poses a challenge to a discourse that characterize Black women's hair as in need of management and control and, by association, women themselves. By not framing women's haircare choices as an explicitly political act, Carolina is also providing a space for women to define how to read their own bodies, thereby fostering a sense of control over their image within a patriarchal system, in which women's bodies are frequently utilized to meet the needs of men. In this space, women can choose to join their body in the collective of an Afro-Dominican politics or an individual politics of self-love. To be sure, even within these spaces, and especially outside them, one cannot control the myriad ways that one's body is read. Even as she tries to open up a space for women's control and is careful not to frame haircare choices as 
moral choices, a political commitment to combating anti-Black racism informs Carolina's motivations. For her, the increasing visibility of natural hair is directly related to a recognition of the contributions, presence, and values of Afro-descendants in the Dominican Republic and the wider Latin American context in which she works.

However, framing these choices as individual ones and minimizing their broader social significance, runs the danger of destabilizing the types of collective mobilization that is necessary to create political change. The idea that the body only represents personal choice is an illusion because the body "can never be a struggle free zone" (Comaroff and Comaroff 1992, 40). Framing the body outside of the political produces a limited interpretation of the behaviors of women who straighten their hair, suggesting that it is a matter of individual psychology more than widespread economic, social, and emotional sanctions that affect women who abstain from hair straightening.

One prominent local activist and journalist involved in a wide range of proimmigrant, anti-racist, and feminist organizations was wary of these social entrepreneurs. Although she participated widely in conferences and even helped organize a November 2015 conference titled El sentido político del "afro": La experiencia de la activista afroamericana Angela Davis, Carmen refused invitations to collaborate with the proprietors of these salons, none of whom attended the event she helped organize. She told me:

A mí me estaban invitando. Ellas han tratado todos los espacios que hay sobre la temática afro ... las mujeres de los salones esos. Yo me he cuidado porque yo no quisiera ... porque en una actividad que es social, se relacione con algo comercial porque detrás de los salones hay una gente que se está beneficiando del problema. Para mí es como mover el problema del salón que te pone blanca, como el pelo liso, mover el problema a un salón que dice que te mantiene afro pero detrás de eso, aún siendo afro, hay un mercado. 
They were inviting me. They have addresses all the spaces that there are on the afro- subject ... the women from those salons. I've been cautious because I didn't want to ... in a social activity, relate it to something commercial because behind those salons are people who are benefitting from the problem. For me, it's like moving the problem from the salon that makes you white, like straight hair, move the problem to a salon that says that it will keep you afro but behind that, staying afro, there's a market.

Carmen rejected the premise that such businesses could be serving the needs of women.

She went so far as to call them racist because they continued to promote the idea that women needed to invest a significant amount of financial and emotional resources in their physical appearance. Statements such as these reflect a preoccupation with the possibility that natural hair promoters were simply replacing a White beauty ideal with a Black one (Tate 2009). Alicia echoed these doubts and saw the natural hair movement as producing its own limiting ideas about beauty. The idea of a salon to treat natural hair was contradictory for her. Natural haircare was such because it could be performed at home as it had been for centuries. The salons dedicated to natural hair communicated to her that one's natural hair was accepted, pero ¿en qué forma? (“in what form?”) These salons advertised that they maintained natural hair, ¿pero como tú quieras? No. Hay un prototipo. Esos salones nos están marcando un prototipo... algo estandarizado." ("How you want it? No. There's a prototype. Those salons are marking a prototype for us ... something standardized.") She found more freedom in the Haitian tradition of hairstyling, which included a larger diversity of styles.

For Carmen, these natural hair advocates did not fully accept their blackness, por eso insisten que te hace tanta vaina ("That's why they insist that you do so many things to yourself.") She read the tutorials, product trials, and services they offered as means of 
transforming blackness in ways that were more acceptable in a racist society. Y hay algunos que se lo tiñen de rubio ("And there are some who dye their hair blond,"), she told me. Solamente lo pueden tener natural si lo tiñen de rubio. Entonces, son manifestaciones del racismo ("They can only have it natural if they dye it blond. So, they are manifestations of racism.") These comments indicate how anti-racist aesthetics can impose its own "normalized racializing standards" (Tate 2007, 306) that reproduce forms of exclusion. Carmen's comments refer to the focus on fashion, self-improvement, and beauty that natural hair communities continue to promote. She is upset by the standards that were continually imposed in these settings and championed instead the idea that the body should be appreciated for its humanity rather than its aesthetic appeal.

In her comments, Carmen draws on a feminist critique of beauty standards as oppressive. Beauty occupies so many of women's resources and its continued prominence does little to challenge the relegation of women to the realm of the body. She criticized the natural hair movement's creation of networks of support, understanding that real liberation comes from the personal conviction that one's body is beautiful. Shirley Tate (2009) suggests that beauty cannot exist without this recognition; beauty "after all is not just there. Beauty must be worked on and worked up. Beauty must be touched, felt, seen and recognized" (25). Therefore, the construction of beauty is an inherently social practice. Natural haircare recognizes the "work on and worked up" aspects of beauty but strives to transform the audiences that matter when evaluating Black women's beauty, precisely through the centering of the like-minded community that Carmen criticizes.

However, at the natural hair events I attended, the women in attendance largely appeared to be happy and confident, outwardly demonstrating little of the pressures to 
conform Carmen describes in her critique of the movement. To be sure, tutorials and product sales were prominent features of these events, promising to enhance women's natural beauty. In addition to these messages of self-improvement. The two public natural hair events I attended were also significantly different, suggesting the diversity of natural hair spaces. The first event, organized as a white party for which attendees were instructed to dress in white clothing, was held in an upscale beachfront restaurant in Boca Chica, a site about a half hour bus ride outside Santo Domingo, known for its robust sexual tourism economy (see Cabezas 2009; Gregory 2014). Certainly, the event's location and dress code created a more rarified atmosphere which may support Carmen's criticsms.

By contrast, an event held a few months later in July was organized in a public park, albeit in a middle-class neighborhood of Santo Domingo, drawing significantly more attendees than the one held at the hotel. The organizer, Miss Rizos, sought volunteers to publicly undergo el gran corte "the big chop," a very close-cropped cut that would eliminate all processed hair. More than spectacle, several women crowded around the woman to offer support. The contradictions are inherent in beauty as a double-edged sword, "as capable of destabilizing rigid conventions and behavioral models as it is of reinforcing them" (Brand 2000, xv). The contrasts between these two events serve to challenge the dualism that Carmen attributes to the movement, showing more complexity.

\section{Conclusion: Splitting Hairs}

The natural hair movement has made strides to challenge the traditional dominance of straightening in the Dominican Republic. Against the hegemonic discourse that separates these practices from racial politics, the experiences of those who dare to wear 
their hair natural illustrate the danger natural hair poses to the dominant system of race relations. Precisely because of the racialization of Afro-textured hair, its increased visibility carries the potential of dismantling the structure of racist discrimination by eroding its connotations with criminality, depravity, and barbarity. Aesthetics are not marginal political concerns but central to struggle; "[i]n a revolution, the established body ideal is one of the first things to be overturned or redefined in favor of a more ideologically appropriate replacement" (Reischer and Koo 2004, 308).

Social theorists have argued that the power of an embodied, performative resistance is often more impactful than purely discursive acts (Butler 1990; Scott 1990). Some, like Miss Rizos, see the potential of a politics of the pajón as key to combatting racial injustice in the Dominican context, where a discourse of racial justice and Black identity are typically absent from the national public conversation. This perspective rejects the limits of the recognizable national subjectivities by preferring an embodied politics over one of identity. Mercer maintains that pride is a "prerequisite for a politics of resistance and reconstruction" $(1987,36)$. Therefore, while a small step, the natural hair movement has potential to spawn a sense of ownership and pride over the physical inheritance of blackness. The question is whether this pride, if not articulated as explicitly Black pride, will be able to erect a bridge to include persons of Haitian descent.

Others argue that natural hair's true subversive potential is only possible with a strong political basis. This perspective was forwarded at the roundtable $E l$ sentido politico del "afro": La experiencia de la activista afroamericana Angela Davis. However, all the theoretical foundation for the conversation utilized the work of US-based scholars operating within the context of the "one-drop rule," whereby any amount of African blood 
places you within the Black identity category. By contrast, Angela Davis, at the center of the talk, would exercise significant skin color privilege as a racially mixed person, if she were located in the Dominican context. Like Carmen, this academic group criticizes the natural hair movement's lack of political and theoretical foundation. However, their politics founded on international discourses parallels the critique that dominant hairstyles in the Dominican Republic are basados en una imagen que no encaja [con] lo que somos ("based on an image that does not fit what we are") (personal communication, March 30, 2015).

In her examination of the role of resistance in quotidian haircare practices among US women, Rose Weitz suggests a narrower conceptualization of resistance to evaluate the liberatory potential of practices. To qualify as resistance, practices must meet two requirements: reject subordination and challenge the ideologies that support it (Weitz 2001, 607). In these terms, the natural hair movement in the Dominican Republic today clearly meets the first requirement as it rejects the privileging of straight hair. It is clear that for the moment, some women participating in the natural hair movement $d o$ conceive of their practice as challenging ideologies. Given the recent conversion of natural hair into moda (fashion), many see the most eminent danger to its radical potential as its appropriation by dominant culture. Aware of the ways the afro became devoid of its revolutionary significance in the US, it remains unclear whether the adoption of the afro by controversial pop culture figures such as "Amara la Negra" (the Dominican-American celebrity) strips its potential to urge a reconsideration of blackness.

In contast, Carolina, the woman behind Miss Rizos did not find the commercialization of natural hair to be a danger. She was proud to be an entrepreneur 
whose work was recognized and compensated within a system that prioritizes capitalist accumulation; she acted on the belief that capitalism and consumerism were "linked to the elevation of a racial identity" (Thomas 2004, 251), representing accommodation within a capitalist system of racial oppression. Limiting access to the language of natural hair may also promote a dynamic whereby those with the freedom to utilize Black cultural symbols are the most economically secure, blocking access to the anti-racist cultural symbols often utilized by Haitian diaspora organizations.

The radical potential of the natural hair movement lies in its ability to make racism visible as the collectivities organized around it work together to challenge practices of racial discrimination, particularly as they occur in state institutions. Its member's bodies serve as clear representations of Africa's presence in the Dominican Republic, a presence erased from the nation's history and landscape. This appeal to Africa provides a potential bridge to the nation's Haitian community, often discriminated for their proximity to blackness. However, the commercialization of natural hair may create cleavages between various kinds of blackness, such as those already existing in the color taxonomy often used in the country and those associated with national identities - either US or Dominican. 


\section{CHAPTER 5}

\section{UNO PAIS SIN}

\section{ROSTRO:}

\section{LOCATING RACE AND COLOR IN THE DOMINICAN NATION}

Somos un país sin rostro ("We're a country without a face"), Yesenia told me. By the time of our interview at the end of my fieldwork in 2016, statements like this one that highlight the diversity of "Dominican looks" had become familiar. For many Dominicans, the seemingly infinite variety of racial and ethnic markers from hair and skin color; eye, nose, and mouth shape; and hair texture is a point of pride. This pride extends beyond the anxieties over protecting Dominican culture and autonomy in the face of Haitian immigration, tourism, and transnational Dominicans. Rather, like Yesenia, many Dominicans celebrate the central role of racial and ethnic mixture as a progressive element of their national identity. Moreover, racial mixture (mestizaje) has been key to the formation of national identity in the post-colonial period in the Dominican Republic and the wider Latin American region.

To be sure, this notion that a Dominican phenotype is undefinable transcended the tight-knit activist circles in which Yesenia was enmeshed, reflecting the nationwide acceptance of mestizaje as a founding racial myth of the Republic. This perspective was shared in a panel as part of Afrodescendencia Fest, a series of presentations and performances organized to commemorate the 1796 slave uprising at the Nigua plantation in San Cristóbal province. The first of these October 2016 events, a panel titled "Perspective on the Material and Immaterial Patrimony of Afro-Descent in the Dominican Republic," consisted of academics and public officials exhorting the public to recognize 
and preserve various elements of the African cultural heritage, from archaeological sites to religious practices. Except for the organizer, a serious middle-aged man who always dressed in the crisp whites of Santeria initiates, none of the invited speakers would be considered Black by Dominican standards.

The penultimate speaker, a 40s-ish professor from a northeastern US college, used the greater part of her allotted time to speak on the remarkable spectrum of Dominican phenotypes, listing a series of surprising combinations, such as rubio, con ojos chinos $y$ piel morena; morena con ojos azules y pelo crespo ("blond, with Asiatic eyes and brown skin; brown with blue eyes and curly hair.") She argued that only through the recognition and appreciation of this multiplicity can the exclusion, silence, and erasure that have marked Dominican politics in the last several years be challenged.

As the woman concluded her presentation, I could see Ernesto, a café con lechecolored bohemian who I frequently ran into at the events, shake his head. He leaned over and muttered, Nuestro problema es no reconocer que somos negros ("Our problem is not recognizing that we are Black.") He repeated this concern in the discussion following the panel, eliciting a resounding applause from the crowd, mostly the typical cadre of intellectuals, students, artists, and activists who frequented the center's events.

For Ernesto, the complicated phenotypical taxonomy that persists in the Dominican Republic fundamentally negates blackness. He is part of a growing group of Dominicans who are skeptical of the utility of multicultural politics for assuring racial equality. Conflict over whether the multiracial nationalism expressed in Yesenia's optimism regarding un país sin rostro, and Ernesto's skepticism about the motivations of multiple skin color 
labels, represent the broader range of positions adopted by contemporary anti-racist activists in the Dominican Republic and beyond.

This chapter examines official narratives around mixture, blackness, and indigeneity in the Dominican Republic. As this project is primarily concerned with the role of race in determining access to nationality for Dominicans of Haitian descent and citizenship rights, I examine how the state has promoted different racial narratives at distinct historical junctures via two key public documents: the census and national identity cards or, cédulas. These narratives themselves show that not all Dominicans internalize the state's racial divisions and hierarchies. However, an understanding of the state's efforts to shape national racial identity vis-à-vis these documents is essential to understanding how activists, the state, and ordinary Dominicans envision an anti-racist future. Building on previous chapters which have focused on the ways blackness and Haitianess are coarticulated in the Dominican Republic, this discussion elaborates on the ways understandings of race are produced at the national level (via identity documents and censuses) and contested at the transnational level (via US-influenced representations of blackness). My analysis suggests that Dominicans of Haitian descent are transcending the limits of national racial ideologies through appeal to transnational racial representations.

\section{Mestizaje and National Identity}

Ernesto's and others' skepticism about the potential for an anti-racist movement informed by narratives of mixture is well founded. Since before the founding of the republic, Dominicans have constructed themselves as mixed-race, adopting the ideology of mestizaje that continues to inform Dominicans' individual racial identity and their 
understanding of the racial composition of their nation (Martínez-Vergne 2005). Therefore, Ernesto joins others who find that mestizaje so far, has not generated the racial harmony promised by its progenitors. Here, I use mestizaje to discuss the foundational idea that exists in the Dominican Republic and other Latin American countries populations are of mixed race origin. I do so to interrogate how activists negotiate Black identities. ${ }^{40}$

Various Latin American intellectual elites, including Simón Bolívar and José Martí in the $19^{\text {th }}$ century, promoted mestizaje as a racial ideology founding a unified national identity vis-à-vis racial and cultural miscegenation (de la Fuente 2001; Miller 2004). Although the mestizaje discourse recognizes the three central racial roots of the region's populations (African, Indian, and European), the African element is marginalized in official racial representations (Hernández 2013; Martínez-Echazábal 1998). Developed as a model to counter the colonial racial order, which rendered most of its subjects incapable of self-governance, mestizaje provided the central scaffolding for early progressive formulations of sovereignty and citizenship in the region during the early $20^{\text {th }}$ century.

In the Dominican Republic, one of the nation's founding fathers, Juan Pablo Duarte (1813-1876), exemplified this ideology in the 1844 poem El Criollo:

Los blancos, morenos, Cobrizos, cruzados, Marchando serenos, Unidos y osados, La Patria salvemos

De viles tiranos $\mathrm{Y}$ al mundo mostremos Que somos hermanos.

\footnotetext{
${ }^{40}$ While this chapter focuses on racial mixture, mestizaje is often used to discuss cultural hybridity as well. Mesitzaje is similar to the term creolization but the former is used most often in the scholarship on Latin America.
} 
The whites, morenos,

Copper, crossed,

Marching serene,

United and bold,

The nation we save

From vile tyrants

And show to the world

That we are brothers. ${ }^{41}$

In the title of this poem, which serves as a call to the cause of independence, Duarte centers on the figure of the criollo, like himself, the American-born descendant of Spaniards. That is, while acknowledging the central role of morenos and cobrizos in the independence struggle against Spain, Duarte imagines the criollo as the ideal national figure.

In this moment, Duarte secures a place in the canon of $19^{\text {th }}$-century Hispanophile Dominican literature, which aims to "produce a sovereign nation while simultaneously appeasing criollo colonial desire to retain whiteness and European cultural dominance" (García Peña 2016, 25). Yet, this gesture is not to be mistaken as analogous to the Spanish colonizers Duarte was mobilizing against. The criollo is both a national and racial figure that incorporates blancos, cobrizos, and morenos, representing the European, indigenous, and Black populations that predominate on the island. Through the advancement of the process of mestizaje, as the Mexican philosopher, José Vasconcelos later conceived it, a unique race would eventually arise from crossracial contact that would unite Whites, Asians (referred to by Vasconcelos as Mongols), Blacks, and indigenous persons (Vasconcelos 1997[1925]). Similar visions of racial mixture served as the foundation for

\footnotetext{
${ }^{41}$ Quoted in Durán $(2013,45)$. See also Mayes $(2014,22)$.
} 
most of the independence struggles in the region in the $19^{\text {th }}$ and early $20^{\text {th }}$ centuries. However, as reflected in Duarte's usage of moreno ${ }^{42}$ in place of negro, effectively diluting the role of the African population, blackness rarely occupied equal places to whiteness in the national imaginary.

\section{Mixed Race Scholarship}

In contrast to Ernesto's skepticism regarding the mixed-race vision of Duarte and other early independence leaders, much of the scholarship on race in Latin America has celebrated mestizaje as a model of racial equity (see Bergad 2007; Degler 1986[1971]; Harris 1964; Hoetink 1971[1967]; Skidmore 1993[1974]). To the US and Western European scholars who dominated the field, the rhetoric of inclusion and celebration of mixture was markedly distinct from formal policies of racial discrimination and segregation in the global north. These scholars pointed to the comparatively low levels of racial segregation, frequency of intimate interracial unions, and the porosity of categories to further their arguments that Latin American and Caribbean societies were non-racist. This wave of research represents what Jean Rahier (2003) calls the scholarly fetishization with notions of hybridity that "tends to obfuscate the oppressive ideological realities" of Latin American racial formation (42).

Despite the differences between mestizaje and US and European racial systems dictated by hypodescent and limpieza de sangre, scholars often failed to examine the continuities between post-independence racial construction and the colonial system. A new

\footnotetext{
${ }^{42}$ Moreno derives from the Spanish word for "moor." It is used in the Dominican Republic to describe a person with dark skin (López 2015).
} 
wave of scholarship inspired by growing anti-racist social movements emerged in the 1980s, offering a more critical examination of the links between mestizaje and the eugenics movement (see Hernández 2013; Miller 2004; Stepan 1991; Wade 2003). This scholarship maintains that while on the surface mestizaje appears to invite heterogeneity, it is more accurately conceived as an "all-inclusive ideology of exclusion" (Stutzman 1981). Contrary to its rhetorical embrace of difference, mestizaje seeks to produce a "single homogenized and emblematic composite" (54), represented in post-independence Dominican Republic by the criollo and later the indio.

In her examination of Dominican racial narratives, Eva Michelle Wheeler (2015) shows how because mixture was the foundation of anti-colonial unity, its origin lies in the Código de Legislación para el Gobierno Moral, Político y Económico de los Negros de la Isla Española ${ }^{43}$ the Spanish colonial code known as the Código Negro Carolino (1784), which regulated the treatment of Black persons in the Spanish colonies. Importantly, this code consecrated racial mixture as a mechanism for reclaiming whiteness after five generations of presence of "white blood" (Wheeler 2015, 35), meaning that White status could be achieved through selective partnering. However, the pathway toward racial mobility was mostly unavailable to mixed-race persons, most of whom were considered "illegitimate," "so much so, that 'mestizo' and 'illegitimate' were practically synonymous" throughout most of the Spanish colonial period in the Americas (Wade 2009, 69). The informality and/or exploitative nature of these crossracial unions blocked access to the bureaucratic channels through which mixed-race persons could prove their lineage.

\footnotetext{
${ }^{43}$ The Legislative Code for the Moral, Political, and Economic Governance of the Island of Hispaniola.
} 
While mestizaje is the dominant register through which scholars have examined racial mixture and hybridity in Latin America, creolization is used in a similar vein by scholars in the broader Caribbean region. Unlike mestizaje, articulations of creolité emerging from English and French Caribbean scholars center blackness in their construction of hybrid identities. Early influential writers in this vein such as Edward Kamau Brathwaite (1971), Jean Bernabé et al. (1990) and Stuart Hall (1993) expand on the negritude movement in their writings but identified creoleness as not reducible to either the African, American (indigenous), or European influences in Caribbean culture. Whereas both Bathwaite and Bernabé et al. adopt more laudatory stances regarding the radical racial, cultural, and political potentials of creolism, as indicated in the title of the article "In Praise of Creoleness" (Bernabé et al. 1990), Hall (1993), and later Shalani Puri (2004) center politics in their examination of hybrid identities. First, Hall (1993) maintains that Caribbean blackness is always-already hybridized, rejecting the purity implied in the juxtaposition between creolism and blackness. Further, Hall centers the politics of representation as a central medium through which identities are made, not merely reflections of identities as such (236). Paul Gilroy (1999) follows Hall through a rich examination of processes of cultural hybridity in the Afro-Atlantic diaspora. Second, in her analysis of hybridity, Puri (2004) takes issue with hybridity's post-nationalist and postcolonialist foundations as implicated by her predecessors. Integrating her analysis with then emergent theories of transnationalism and globalization which predicted the nationstate decline she argues that creolism, like mestizaje is not opposed to nationalist projects but, has supported them, as especially exemplified in Latin America. 
As Puri points out, after independence male elites, mostly light-skinned criollos like Duarte, tied mestizaje to the idea of national progress. Years later, the criollo Mexican intellectual, Vasconcelos, often considered the central architect of modern mestizaje philosophy, conceived it as a process of blanqueamiento (whitening), wherein "[t]he lower types of the species will be absorbed by the superior type. In this manner, the Black could be redeemed, and step by step, by voluntary extinction, the uglier stocks will give way to the more handsome" (1997[1925], 30). Moreover, this evolutionary process would result in the natural selection of the best traits of different racial populations, resulting in a "cosmic race" superior to any individual racial and ethnic group. These ideas were shaped by both the eugenicist science that centered reproduction in human progress and the concomitant idea that Blacks were incapable of self-rule.

\section{Race and Sovereignty after the Haitian Revolution}

The ideology of mestizaje took root in most of post-colonial Latin America during the $19^{\text {th }}$ and $20^{\text {th }}$ centuries. In the Dominican Republic, the proximity of Haiti, the impact of its 1791 revolution, the Haitian occupation of the entire island of Hispaniola (1822-44), and the successive wars of independence are important elements of the framings of race and blackness. Therefore, much of the scholarship on race and nation has centered on the history of this relationship. As the first sovereign Black republic in the region, Haiti exposed the consequences of defying the global racial order. The Haitian Revolution decoupled blackness and unfreedom produced under slavery; all Haitian citizens were considered Black after 1804. However, nations at the brink of independence feared meeting the same fate as Haiti: economic sanctions, withheld recognition, and the payment of 
reparations. In the post-colonial context, Dominicans began to differentiate themselves from the White oppressors they sought to overthrow, but because of the relative absence of plantation-based slavery, the existence of a large free colored population, and their efforts to distinguish themselves from Haitians, most did not identify as Black (Sagás 2000, 23). The utility of this "racial" differentiation between Dominicans and Haitians was confirmed during the US occupation of Hispaniola in the early $20^{\text {th }}$ century, when troops withdrew from the Dominican Republic a decade before returning rule to Haiti, a decision largely based on Dominicans' ability to make claims to a civilizing discourse that associated whiteness with progress, reason, and prosperity (Candelario 2007). Therefore, mestizaje served not only as an internally directed unifying project, but to project an image of the nation's racial composition to the outside world.

Historian April Mayes (2014) argues that progressive political intellectual Pedro Francisco Bonó was openly critical of the privileging of Black identity in the Haitian revolution's iconography, which he found more limiting than the criollo identity adopted by most Dominicans at the time. Bonó and other independentistas believed that the Haitian vision of Black nationalism would exacerbate Dominican racial divisions (Mayes 2014, 27). For Bonó, mestizaje not only made sense given the ways Dominicans had come to understand themselves, as a mixed population whose condition of freedom and nationality removed them from the "Black" category, but also served to quell racial anxieties that accompanied the nation-building process. Despite Haiti's own history of European colonialism, Dominicans usually view Haitians as more purely Black than they are.

However, this narrative of the development of mixed race identity in the Dominican Republic in opposition to Haiti naturalizes the difference between the two nations. 
Milagros Ricourt (2016) argues that US colonial and Dominican nationalist narratives exaggerated the differences between how race was formed on the different sides of Hispaniola. This perpetuation of racial difference has furthered efforts to maintain Haitians as an exploitable source of labor. Therefore, Ricourt finds that mestizaje not only served to legitimate the predominant practice of racial crossing and provided persons of color with opportunities for social mobility; it also met White elites' need to contain the racial ascendency of the newly liberated population through the maintenance of White supremacy. As such, the turn away from Haiti provided a clear indication that Dominicans refused to participate in the racial radicalism represented by the Haitian Revolution.

\section{Racial Democracy}

Despite the widespread recognition by Dominicans who adopt racial improvement strategies that fair-skinned persons garner social advantages, most Dominicans also characterize their society as a "racial democracy" (Freyre 1946), wherein all citizens, regardless of race, are given equal opportunities. Moreover, the Dominican Republic often appears as a "racial paradise," wherein social relations are distinguished for their high degree of racial harmony, even under slavery (Hoetink 1971; Tannenbaum 1992[1946]). Similar ideologies operate in Puerto Rico and Brazil. Writing in 1881, Bonó described the colonial system as one in which el español aportó suma benevolencia, gran caridad y mucha dulzura en las desigualdades sociales que tal sistema imponía. Sus relaciones de mayoral y dueño, de amo y esclavo se sostuvieron en una igualdad relativa ("The Spaniard bestowed the utmost benevolence, great charity, and much tenderness in the social inequalities which that system imposed. His relations of foreman and owner, of master and 
slave were maintained in relative equality") (AGN 2007, 54). Less than a generation later, the US would occupy the entire island, finding the occupants unsuitable for self-rule [ostensibly based upon their racial composition] and setting the stage for Trujillo's rise in 1931.

Under Trujillo, the Dominican state claimed exceptionally egalitarian race relations to emphasize its modernity. Ideologies of miscegenation presented opportunities for Dominican elites to distance themselves from Haiti and its revolutionary ideals, and from the firm racial line drawn by US and European elites. Through the ideology of mestizaje, locals claimed moral superiority for overcoming internal racial conflicts. Trujillo manipulated this image by inviting Jewish refugees from Nazi Germany to resettle in Sosúa on the island's northern coast. Despite mild public acknowledgment of measurable inequalities in the quality of life for dark and light-skinned Dominicans, these differences are most often ascribed in popular discourse to individually-held prejudices rather than a systemic concern.

My interactions with ordinary Dominicans evidenced Dominicans' adoption of these views. Frequently, when introducing myself and explaining the purpose of my visit there, interlocutors took issue with my use of a racial framework to examine inequality in their country. In one such interaction, a young male professional who had spent several years working in the eastern coast of the US and having recently returned to the island told me, Existen unos prejuicios ("There are some prejudices"), pero no es como allá ("but it's not like there.") My own US citizenship, and Dominicans' cache of knowledge about the US, often made the United States a measuring rod for racism. Dominicans proudly told me 
that their government had never instituted legal segregation, and defensively asked why I did not stay in my own country if I really wanted to learn about racism.

\section{Race in the Dominican Census}

The census is a fundamental tool for understanding the interplay between state racial formations and ordinary citizens' understanding of race. Although the Dominican Republic has not collected data on race since 1960, much can be learned about how the state has approached the question of racial identity in the past and how it conceived race at varying points over the course of the four decades (1920-1960) when racial data were captured. Official figures for these years as reported by the Oficina Nacional de Estadística are presented in Table 1 including, when available, the categories provided to the enumerator and how the results were labeled in reports (as color, race, or both). The categories by which the state organizes race continue to influence the ways Dominicans understand race. Census data are a rich source of information as the "central administrative technology" of what David Theo Goldberg (2002) describes as the "racial state" (188). The historically variable categories in the census affect what Goldberg calls "state speech" as it "circulates revised and reworked popular categories of racial conception [and] lends the authority of the state to racial distinction" (189). Beyond its local impact, as a public document the modern census serves as a "national portrait" that communicates the contours of national identity abroad as well as to ordinary citizens (Loveman 2014, 28). Therefore, census categories not only reflect existing racial classifications but also contribute to shaping them. Census categories carry weight, not solely through the work of the armies

of interviewers who were previously commissioned to go door-to-door, subjecting the 
entire population to its racial categories, but also by projecting this national racial image at home and abroad. A brief history of race in the Dominican census is illustrative of how the state envisions itself in racial terms.

While the impetus toward blanqueamiento, or generational whitening, remains, many Dominicans now imagine that mestizaje has succeeded in the creation of a homogenous populace combining European, Indigenous, and Black ancestry. Accordingly, the state suspended the collection and distribution of racial data in its national census after 1960. Often, census racial data are used to measure progress toward racial equality. However, understanding that Dominican society has overcome racial inequity via the production of a universal racial identity (the mestizo/mulato), the race question was eliminated after the completion of only four censuses. This analysis of the census demonstrates how it was utilized to represent this racial progression.

The 1920 Census, completed under US military occupation and the country's first ever completed post-independence, collected data on race but did not proscribe the categories to be used (ONE 2012, 17). The form employed by enumerators simply featured a blank column labeled "color or race," which they would complete based on their observation of the respondents. Without clear organizing categories, enumerators relied on common understandings intelligible to both the general population and the Secretary of Interior and Police, which was charged with the census. While the precise instructions for 1920 census takers have not been archived, in all subsequent years, enumerators determined racial classification. This reliance on visual observation to divide persons into race and color categories (used in different years) suggests that race is una categoria fenotípica percibida (a phenotypically perceived category), as described in a 2012 report 
by the Office of National Statistics (ONE), the agency responsible for collecting and disseminating national population statistics (ONE 2012, 18). The 1920 data presented in Table 1 show a population distribution concentrated along the middle racial category, with half (49.7) of the population identified as mestizos and near equal proportions of Black (25.4) and White (24.9) persons comprising the other half of the population.

\begin{tabular}{|c|c|c|c|}
\hline Year & Label & Options & Results (Percent) \\
\hline 1920 & Color or Race & Open-ended & $\begin{array}{l}\text { Blanco: } 24.9 \\
\text { Mestizo: } 49.7 \\
\text { Negro: } 25.4\end{array}$ \\
\hline 1935 & Color or Race & $\begin{array}{l}\text { Blanco } \\
\text { Negro } \\
\text { Amarillo } \\
\text { Indio }\end{array}$ & $\begin{array}{l}\text { Blanco: } 13.0^{45} \\
\text { Mestizo: } 67.5 \\
\text { Negro: } 19.4 \\
\text { Amarillo: } 0.02\end{array}$ \\
\hline 1950 & $\begin{array}{l}\text { Color (Determined by } \\
\text { enumerator) }\end{array}$ & $\begin{array}{l}\text { Blanco } \\
\text { Negro } \\
\text { Mestizo } \\
\text { Amarillo }\end{array}$ & $\begin{array}{l}\text { Blanco: } 28.1 \\
\text { Negro: } 11.5 \\
\text { Mestizo: } 60.4 \\
\text { Amarillo: } 0.03\end{array}$ \\
\hline 1960 & $\begin{array}{l}\text { Color (Determined by } \\
\text { enumerator) }\end{array}$ & $\begin{array}{l}\text { Blanco } \\
\text { Negro } \\
\text { Mulato } \\
\text { Amarillo }\end{array}$ & $\begin{array}{l}\text { Blanco: } 16.1 \\
\text { Negro: } 10.9 \\
\text { Mulato: } 72.9 \\
\text { Amarillo: } 0.1\end{array}$ \\
\hline 1981 & $\begin{array}{l}\text { According to the } \\
\text { physical characteristics } \\
\text { and accent (determined } \\
\text { by the enumerator) }\end{array}$ & $\begin{array}{l}\text { Dominican } \\
\text { Haitian } \\
\text { Other Nationality }\end{array}$ & $\begin{array}{l}\text { Dominican: N/A }{ }^{46} \\
\text { Haitian: N/A } \\
\text { Other: N/A }\end{array}$ \\
\hline $1970 ; 1993-2010^{47}$ & $\mathrm{~N} / \mathrm{A}$ & N/A & N/A \\
\hline
\end{tabular}

${ }^{44}$ Adapted from Oficina Nacional de Estadística, "La variable étnico-racial en los censos de la población en la República Dominicana," accessed March 13, 2018.

www.one.gob.do/Multimedia/Download?ObjId=1938, p. 17.

${ }^{45}$ Oficina Nacional de Estadística, “Censo Nacional de Población,” acccessed February 19, 2015, http://www.one.gob.do/Estadisticas/302/censo-1950.

${ }^{46}$ Results of the 1981 census are available, but the results of the question pertaining to Dominican or Haitian identity are missing. Oficina Nacional de Estadística, "Censo 1981," accessed March 8, 2018, https://www.one.gob.do/censos/poblacion-y-vivienda/censo-1981.

${ }^{47}$ Years the census did not include a racial/ethnic question. 
The subsequent 1935 census results reported in Table 1 demonstrate a decline in both the White (13.0) and Black (19.4) population and a surge in the mestizo category (67.5). A 1948 treatise on the second census, Historia y estadística de la República Dominicana, highlighted this trend, eliminating the largely Black immigrant population (including Haitians and cocolos) from its analysis to argue that the nation was moving toward the uniformity of mixture. ${ }^{48}$ Identifying shrinking White and Black groups as an improvement, this work illustrates that mestizaje sought to eliminate all racial distinctions, not just blackness. To be sure, Vicente Tolentino Rojas, the author of the treatise, was influenced by the prevailing social context in which eugenicist "scientific" ideologies prevailed. However, the reading of mestizaje as overlapping with White supremacy ignores the more complex ways that Dominicans grappled with their indigenous and African roots.

The following census taken in 1950 reported a notable decline in both the Black (11.5 percent) and mestizo (60.4 percent) population, coupled by a significant increase in the proportion of Whites (28.1). Taken at the height of the Trujillo regime, this census indicated a reversal of the pattern of mixing established in previous years. ${ }^{49}$ Additionally, the census questionnaire removed the term raza (race), while maintaining the term color. The official presentation of the results makes it clear that its author intended to distinguish

\footnotetext{
${ }^{48}$ The National Office of Statistics reports that this census collected data on blancos, negros, indios, and amarillos. However, the official census report available through this office does not include data on race or color. Frank Moya Pons (2010), citing Vicente Tolentino Rojas (1948), provides data only on these three categories.

${ }^{49}$ While some of this change may be attributable to the entry of Jewish refugees during WWII, only about 700 reached the settlement established in Sosúa. Additionally, the decrease in the black category can, in part, be attributed to the racially and ethnically motivated 1937 border massacre in which up to 17,000 Haitians and Dominicans perished (Turits 2003).
} 
color from race, reporting that "the color, not the race, was determined of registered people" (Simmons 2009, 31). However, the report explained that if the enumerator could not determine the respondent's color (either White, Black, Mestizo, or Yellow), he should ask (Simmons 2009, 31). These instructions show that color was not exclusively based on the enumerator's evaluation of the person's phenotype, a situation that would never produce the need to ask the respondent. It suggests that although the census purports to measure "color, not race" that "color" only served as a proxy, maintaining an attachment to social meanings and value. Therefore, although the authorities attempted to emphasize the racial homogeneity of Dominicans via mestizaje, their use of color implies that it maintained and promoted hierarchichal racial divisions.

Contrary to efforts to distinguish the Dominican Republic as a colorist and not a racial regime, in his analysis of these trends, historian Frank Moya Pons (2010) suggests that concerns about the racial profile of the nation abroad influenced the census racial data, as was his experience as a student attending the training sessions for 1960 census surveyors. He recalls that the trainer instructed the group to register darker-skinned persons as white or mulatos:

recuerdo perfectamente que la profesora nos decía que el gobierno quería que la población dominicana se presentara ante el mundo como un país avanzado con mucha población blanca. "Después de todo lo que ha hecho el Jefe (Trujillo) por el país," decía la entrenadora censal, "la República Dominicana no puede presentarse con una población mayoritariamente negra como si fuera una nación africana."

I remember perfectly that the instructor told us that the government wanted the Dominican population to present itself before the world as an advanced nation with a large white population, 'After everything that the Boss (Trujillo) has done for the country,' the census trainer said, 'the Dominican Republic cannot present itself with a majority black population as if it were an African nation.' (Moya Pons 2010, 51) 
Moya Pons' recollection of these events suggests that the national census functioned not only as a means of measuring race, but also to make race both domestically and abroad. These comments highlight what Mara Loveman identifies as the outwardly directed function of censuses, which were initially implemented to demonstrate the equivalency of Latin American nations with the "“civilized nations' of Western Europe” $(2013,104)$. The instructor's fear that the Dominican Republic would present itself as an "African nation" was an especially relevant concern in 1960, given the continuing struggles of nations on the African continent to gain their independence. Therefore, the trainer's comments highlight the racing of modernity on a world scale, where modernity is defined as White. This is especially the case on an island vulnerable to foreign intervention, as it was when the US occupied the Dominican Republic in 1965.

Even with these expressed concerns about the Black population, the mulato category represented mixed-race persons in the 1960 census, diverging from the previous use of mestizo. Both terms signaled specific racial mixtures in the Spanish colonial period, mestizo indexing the offspring of a white-indigenous union and mulato a White-Black union. This centering of blackness in the final years of the Trujillo regime, infamous for its racist rhetoric and policies, is surprising. However, mulato, as a racially intermediate category, may have been a category Dominicans increasingly identified with at the time. With mulato as the mixed-race signifier, as indicated by the results in Table 1, one-tenth more claimed membership in the intermediate category. The decline in those identified as White is proportional to the increase in the intermediate category, implying that the change can be primarily attributed to those leaving the White category. Further, the proportional share of Black and "yellow" populations remained steady from the previous survey. 
Although 1960 was the last year the Dominican state included a racial category, a 2012 report on racial and ethnic categories in the census includes the year 1981 among those that collected racial data. Therefore, 1981 is included in the results reported in Table 1 despite the exclusion of results for this question on the census reports. The report justifies its inclusion because la pregunta está referida al fenotipo (alusión a raza) y el lenguaje (alusión a la etnia), aunque las categorías de respuesta corresponden a la nacionalidad de la persona censada ("the question refers to phenotype [allusion to race] and to language [allusion to ethnicity]"), although the response categories correspond with the nationality of the interviewee) (ONE 2012, 17). An excerpt of the question from the original 1981 Census form (Figure 7) reads, [d] e acuerdo a las caracteristicas fisicas y acento al hablar el empadronado es ("according to the physical characteristics and accent when speaking the registree is") and provides Dominican, Haitian, and other nationality as possible responses. This treatment of race in the census reveals the central role of the Dominican state in the ascription of racial difference onto the Haitian diaspora. Published by the agency in charge of collecting and disseminating these data, the report repeats the logic that constructs "Haitian" as a distinct racial category. The instructions to enumerators also made it possible for them to include naturalized Haitians, as well as native-born Dominicans — both those with or without Haitian descent - under the Haitian category. As a tool to delimit national boundaries, this census renders Haitians both racially (because of their phenotype) and culturally (because of their accent) outside the boundaries of dominicanidad. However, this policy is a divergence from the convention established in the two preceding censuses, which identifies Haitians according to their nationality. 
Figure 7 Question No. 40 from the 1981 Census Form

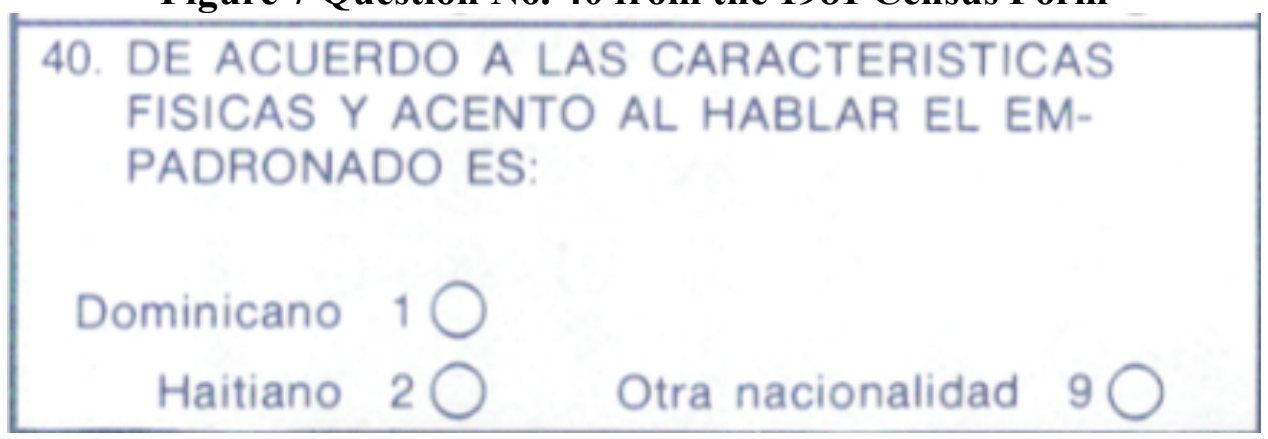

"According to the physical characteristics and accent when speaking the registree is: Dominican 1; Haitian 2; Other nationality 9. Source: ONE, 2013, "República Dominicana: Boletas utilizadas en los censos de población y vivienda 1920-2010," p. 57.

An overview of how race, color, and Haitianess are categorized and enumerated in the Dominican censuses from 1920 to 1981, when the census last included any measure of race, color, or ethnicity, reveals that these concepts are used in ways that complicate a straightforward understanding of their meaning in the Dominican Republic. Not only are they used interchangeably and with overlapping meanings, the structure of the questions and the responses they generate show significant slippage between race and color. Both the 1920 and the 1935 censuses use these terms interchangeably and report categories that avowedly refer to biological descent. The one exception is the inclusion of amarillo, which, although a color, applies exclusively to Asian persons. This use suggests that racial understandings correspond with phenotypical ones; that is, color is a proxy for race.

That enumerators, not the censused individuals, assigned racial and color categories increase the likelihood that they are subject to manipulation by state envoys, as in the case taken from Moya Pons cited above. However, the taboo that surrounds the discussion of racial identity makes this one of the few acceptable methods for collecting such data (Duany 1998, 156). The data tell a story that aligns with the impetus of mestizaje, one of increasing racial mixture and meeting in the middle in the Dominican Republic. They 
confirm that mestizaje is not synonymous with whitening. Although it aims to gradually fold in any distinguishable Black population through the progressive lightening of dark skin tones and increasing the prominence of European phenotypical features, the end goal is not a population indistinguishable from colonial Whites, but, as Candelario (2007) argues, is distinct from both Black and White identities.

However, the sudden disappearance of racial and color categories after 1960 aligns with an official discourse of racial homogeneity, what Rahier (2008) terms "monocultural mestizaje." After almost two-thirds of the Dominican population were registered as mulatos, if the same pattern of movement into the median category had continued, almost every Dominican would be brought into the folds of mestizaje. The state's decision to discontinue the collection of racial data has effects both external and internal to the country. First, it aligns with international trends toward publicly disavowing the significance of race as a social category. Secondly, it works internally to silence racial protest by delegitimizing the articulation of group-based claims.

While racism and racial struggle never completely subsided during this period of a region-wide turn against racial statistics, race did not again become an important category for state analysis until the 1990s. However, the Dominican Republic is an outlier in a trend embracing multiculturalism that has swept the region (see Hale 2006; Hooker 2005; Rahier 2012). While several census bureaus in places such as Mexico and Colombia have moved toward a broader recognition of indigenous and Afro-descendant peoples, the Dominican Republic has eliminated color categories from national identity cards and has not acted on a proposal forwarded by ONE to include a self-reported racial question to conform with 
international standards. In the following section, I examine the cédula as the most recent state-produced document of Dominican color.

\section{Race, Color, and Cédula Categories}

Until 2014 cedúlas, national identity cards, provided four major groupings of skin color (piel): white ("b" for blanco), black ("n" for negro), yellow ("a" for amarillo) and Indio ("i" for indio) ${ }^{50}$ However, the Dominican state did not publish data on the frequency and method with which enumerators applied these terms to the population. No official instructions to the agency's bureaucrats exist, although ethnographic studies of the process confirm that most Dominicans are designated as indio and black is applied almost exclusively to Haitians (Howard 2001; Simmons 2009). In addition, ethnographic research has found that the folk term indio is often qualified by references to skin shade, such as claro (light), or oscuro (dark), and even lavao (washed) and sucio (dirty) (Duany 2002).

As in the national census, employees determine color classification on the cédula, but, as several young activists who had succeeded in securing a black marker, individuals could and did shape the process influencing how they are categorized. Of the four persons who recounted their experience at the cédula office with me, all had experienced some form of resistance when requesting Negro on their cédula. Labeling oneself as black was associated with low self-esteem and typically reserved for Haitians. Rosa's recollection of her attempt to have her cédula reflect her Black identity demonstrates that the state's chosen categories and labeling practices do not always align with how Dominicans identify

\footnotetext{
${ }^{50}$ See Kimberley Eison Simmons (2008) for an examination of the cedualization process.
} 
themselves. After teasing her sister for having a cédula that stated her color as indio, when Rosa became eligible to extract her first identity document at 18 , she pleaded with the clerk, Por favor, no pongan una 'I' cuando me vaya. Por favor pon negra. Soy negra, no soy india (“Please don't put an 'I' when I go. Please, put black, I'm black, I'm not india.") To her disappointment, Rosa received a document labeling her India.

Rosa's narrative substantiates that that cédula categories do not necessarily reflect how Dominicans construct their racial identities (see Howard 2004; Roth 2013; Simmons 2009). While the data gleaned from these documents may not accurately reflect how ordinary Dominicans conceive of their racial identity, they indicate the state's preoccupation with defining the "national phenotype." ${ }^{51}$ However, unlike the census racial categories discussed above, these data are not made public and such classification serves primarily as an intimate racial encounter through which the state exercises its classificatory authority.

On one hand, the state's adoption of a nonracial discourse aligns with the variation of "color blindness" found in the US that temporalizes racial inequality in the past. One major difference is that while the insistence on racial homogeneity undermines efforts to organize as racialized minorities, Dominican society remains highly color-conscious. As in other former Spanish colonies in the Caribbean, Cuba and Puerto Rico, Dominicans, either strangers or acquaintances, regularly hail each other by skin color.

Eugenio, a 25-year-old university student of both Haitian and Dominican parentage, was uneasy with this practice: Hay un término ahora, muy popular: moreno. No

\footnotetext{
${ }^{51}$ David Howard (2001) found that more than half of his interviewees in the upper middle-class neighborhood of Gazcue were classified as white on their cédulas, despite only 4 percent describing themselves as such in interviews (48).
} 
me gusta (“There's a term now, very popular: moreno. I don't like it”), he told me. When I asked why, he went on:

No me gusta porque moreno es un apellido. Yo soy negro. Si una persona me dice, “¡Ay, negro!” está mejor ... No está bien, pero está mejor que moreno. Pero tu color no es tu nombre y no debería de ser así. Lamentablemente, lo es y hay que lidiar con eso. Por ejemplo, blanquita. Eso es feo. De mí no vas a escuchar eso. Es una vaina, es una cosa de educación también, de principio... Yo no te puedo llamar por tu color.

I don't like it because moreno is a surname. I am Black. If a person says to me, "Ay, Black!" it's better... It's not good, but it's better than moreno. But your color isn't your name and it shouldn't be like that. Unfortunately, it is and you have to deal with it. For example, blanquita [white girl]. That's ugly. You're not going to hear that from me. It's a vaina [thing], it's a matter of education too, of principle. I can't call you by your color. ${ }^{52}$

As Eugenio's discomfort suggests, the practice of referring to someone by his or her color is ubiquitous and generally accepted in the Dominican Republic. Where Eugenio sees the quotidian practice of addressing someone by their color as an overt machination of racism, despite demonstrating a high level of color-consciousness, most Dominicans do not understand this practice as racist. Further, like the Dominican women in the previous chapter, Eugenio proudly identifies as Black despite dominant portrayals that island-based Dominicans rarely do so.

\section{Indio and the Racial Middle}

Scholars have considered this color-based system an obstacle to antiracist efforts. Carl Degler (1986[1971]) argues that in the Brazilian case the institution of intermediary categories inclines darker-skinned populations to repudiate blackness and utilize a "mulatto

\footnotetext{
${ }^{52}$ Interview in Santo Domingo October 15, 2015.
} 
escape hatch" to secure improved treatment. Degler also adopted his escape hatch metaphor to the possibility of avoiding racial polarization via the inclusion of the median category. At the national level, the inclusion of the median category is often linked to the weakening of Black oppositional movements by incentivizing investments in Whiteness (Degler 1986[1971], 276). Candelario (2007) and Duany (2002) have applied this notion to describe an "indio escape hatch" in the Dominican Republic (Candelario 2007) and Puerto Rico (Duany 2002), where claims to indigeneity (Taíno ancestry) are used for upward social mobility.

As shown in the formatting of the census questions previously considered, in every instance, even when the word race was used, what was being measured relied almost exclusively on the enumerator's determinations of skin color. However, most contemporary observers argue that skin color and race are not co-extensive and that these phenotypical descriptors do not correspond to biological concepts of descent. Since the institutionalization of the indio label in the 1930 cédula, it has been the primary official skin color category. While literally meaning Indian, or indigenous, contrary to some scholars who utilize its literal translation (e.g., Howard 2001; Safa 1998), its usage more accurately aligns with that of a brown skin color. Although indio reflects a founding myth that Dominicans' dark skin derives from their indigenous ancestry—an ideological move that distances them from blackness - almost no Dominican I encountered traced their ancestry to the island's native inhabitants. Historian Carlos Esteban Deive, who has published widely on questions of race and slavery in the Dominican Republic, defines indio in his Diccionario de dominicanismos as a euphemism usado para nombrar como mulatas 
a las personas de color negro ("used to call mulata persons who are black") (Deive 2006, 112). In no way does he tie the Dominican usage of indio to indigenous persons.

Categories, such as indio, moreno, or rubio, are skin color descriptors whose use in no way undermines the fundamental societal investment in the mixed-race ideology. On the cédula, these categories are clearly marked as skin color, not race. Efforts to treat these, especially the indio category, as racial has led to erroneous claims that Dominicans construct themselves as primarily descendants of the Taínos, the island's native inhabitants (see Candelario 2007; Simmons 2009). In her study of historical and contemporary racial representations among Dominicans, Candelario argues that indio best represents a preference for an intermediate racial aesthetic that falls between white and black. She writes, "Lo indio" is best conceived as "the middle term, the central point of the racial continuum, the 'native' alternative to foreign blackness and whiteness alike" $(2007,58)$.

While arguing that indio is conceived as a mixed-race identity, both Candelario and Simmons maintain that the widespread use of this term minimizes the African diaspora in the dominant racial imaginary of the Dominican Republic. However, to interpret indio simply as a foil for anti-blackness erases the complexity of Dominican self-construction that cannot be captured through the prism of negation alone. A 2011 editorial in the Listin Diario by Indhira Suero, author of the blog about race titled Negrita come coco, highlights how both dark-skinned and light-skinned Dominicans are regularly subjected to disparaging remarks about their color. Kimberly Eison Simmons' (2009) examination of how indio was deployed in the emission of cédulas found that calls to change the category proposed to replace it with mulato or mestizo, evidencing that indio indexes a mixed-race identity (36-37). 
Debates leading up to the 2014 cédula reform map out the contemporary landscape of race and color in the Dominican Republic. According to Yesenia, these debates had become so intense that in the end, they decided to leave color out of the document's redesign. The rationale behind the JCE's ultimate decision to eliminate the category is unclear, as the process was largely opaque except for the leaking of a 2011 proposal to change indio to mulato.

Several published editorials expressed conflicting opinions on what their authors considered the most accurate ways of categorizing Dominican identity. A 2011 editorial in the Listin Diario begins with the phrase, Aqui nos hemos inventado un color, el "indio," que no suele aparecer en el policromo universal ("Here we have invented a color, 'indio', which does not usually appear in the universal polychrome") (Listín Diario, 11 November 2011). Arguing that Dominicans adopted the term indio para no creernos negros ("to believe we are not black"), the author suggests they use mulato instead so that los negros que recelen de su color se esforzaran por lograr que se les categorizara como "indio oscuro" o "indio claro" en las cédulas, como la forma de hacer más suave y elegante el matiz de su piel ("the Blacks who fear their color strive to accomplish that they are categorized as 'dark indio' or 'light indio' in the cédulas, as the means of making the hue of their skin more soft and elegant.") The author invalidates the use of indio as anything but a means to negate blackness in a society that associates dark skin with the antithesis of "softness" and "elegance."

The effort to institute a more accurate system of categorization is reflected in the efforts of the JCE to tie color more closely to ethnicity. A 2011 JCE report, which was leaked to the press, found that the changes were necessary given that los colores que se 
establecen por etnia son el mulato, negro y blanco, entonces el Indio desapareceria ("the colors established by ethnicity are mulato, black, and white, thus the Indio would disappear.") The capitalization of Indio alone suggests that the authors of the report considered it not only a color, but also a formal group, presumably an ethnic one (Listín Diario, 11 November 2011). However, the JCE's argument for eliminating this category hinges on the claims that mulato, black, and white are more aligned with Dominican ethnic identity. Given that ethnicity is typically defined by a shared culture and language, the inclusion of the European, African, and mixed elements alone is interesting. Furthermore, because these are more accurately racial terms, their description as "ethnic" in this document suggests that the state presupposes a universal linguistic and cultural identity, with color being the primary axis of internal distinction in the Dominican Republic.

Another editorial applauds the JCE's decision to excise skin color from the official identity document. The author recalls that when requesting the label negro on his document, he had to librar una batalla verbal con la joven que me atendia para que concediera mi petición de ponerme negro en el color de piel pues ella juraba que yo era indio oscuro llegando, inclusive a cuestionar mi autoestima por mi afán de que pusieran negro ("wage a verbal battle with the youth attending me so that she would concede my petition to put black in the skin color as she swore that I was indio oscuro, going so far as to question my self-esteem for my insistence that they put black") (Alvarez de los Santos 2016). This reporter's story echoes many I heard from other racially conscious Dominicans, who had similarly insisted that their skin be recorded as black, only to be met with the protests of the state employee, who insisted that only Haitians or persons with 
little self-worth merited the Black label. Others who reported having intervened in the process of state racialization expressed a defiant pride in having done so.

Dominican Studies scholars' reexamination of the term indio and their attention to Dominican blackness in general has put them at the forefront of engagements with the inclusionary aspects of mestizaje. The radical elements of the ideology had been dismissed in the academic turn against the philosophy which framed any revolutionary impulse as a mere façade erected to mask elites' White supremacist efforts. Some scholars have argued that mestizaje should be revisited and identify positive aspects within in (de la Fuente 2001; Mayes 2014; Wade 2005). As Alejandro de la Fuente (2001) argues in the Cuban case, elites' influence was not so strong that they were able to employ a discourse of inclusion without offering some of the benefits promised to racially marginalized groups. This was a lesson learned in the revolutionary period when independence efforts in Cuba (and the Dominican Republic) initially failed because of elites' failure to include abolition among their central demands. Instead, de la Fuente argues that mestizaje, like most ideological tools, was subject to "disparate interpretations." Therefore, while it served to "obfuscate" the continued persistence of racism, it also supplied the discursive foundations upon which anti-racist organizers could pursue progress towards the goals of racial harmony outlined in mestizaje.

\section{The Color Continuum}

Jorge Duany (2002) identifies at least 19 skin color terms used in Puerto Rico, many which are used in the Dominican Republic (Roth 2012, 19). Thus, unlike the US racial model, intermediate groups acquire a distinct status between the poles of black and white. 
Yet, skin color descriptors are often contingent, and because they are liable to change according to context, they often do not result in the formation of self-identified groups. The various skin color labels can be mapped along a hierarchy where proximity to blackness is devalued and whiteness is desired.

Dominicans adopt a language of racial homogeneity whereby national identity stands in for racial identity, yet color is an important factor in daily social interaction. Therefore, when dealing with co-nationals, Dominicans claim to be racially neutral but highly color conscious. While these color categories are subjective and a person is often not fixed within them, given the maintenance of a political and economic dominance of light-skinned persons, they are not entirely free of moral and other valuations.

Figure 8 Main Dominican Skin Color Classifications

\begin{tabular}{|c|c|c|c|c|}
\hline $\begin{array}{l}\text { Blanco } \\
\text { Rubio }\end{array}$ & Indio claro & $\begin{array}{l}\text { Indio } \\
\text { Trigueño } \\
\text { Mestizo }\end{array}$ & $\begin{array}{l}\text { Jabao } \\
\text { Indio oscuro }\end{array}$ & $\begin{array}{l}\text { Moreno } \\
\text { Prieto } \\
\text { Negro } \\
\text { Haitiano }\end{array}$ \\
\hline
\end{tabular}

Figure 8 above illustrates an excerpt of the skin color terminology most commonly utilized in the Dominican Republic. Other scholars have documented additional terms not featured here, such as grifo and colorao (Duany 1998, 162) in Puerto Rico. In my fieldwork, those most commonly heard in daily practice were negro, rubio, moreno, and indio. The variety of categories utilized even exceed those already noted by scholars, including indio lavao, indio canelo, negro tinto, negro retinto, jojoto, and blanco jipato (Listín Diario, 3 December, 2011). Focus groups conducted by Jim Sidanius et al. (2001) identified just six racial classifications commonly used by Dominican participants: blanco, 
trigueño, indio, mulato, moreno, and negro. The abive chart demonstrates only an approximate location of these terms along a black-white continuum, given their imprecise definitions and irregular usage. Many scholars condense this typology into three salient categories: black, white, and intermediate (Gravlee 2005; Wade 1997). Moreover, these terms do not directly correspond to the epidermis alone, but factor in hair texture and other physical features. For example, many of the color terms in Deive's Diccionario de dominicanismos include a description of hair texture. The entry for indio canelo describes someone with la piel del color del chocolate claro, el pelo lacio y las facciones "regulares" ("skin the color of milk chocolate, straight hair and 'regular' features") $(2006,111)$. While "regular" features are not well-defined, their inclusion in Deive's dictionary indicates that color, hair, and other physical characteristics are important to Dominicans' process of racial categorization. Deive's use of "regular" also implies a hierarchy in what is considered a "typical" Dominican look, implying that some phenotypes are "irregular." This statement contrasts sharply with Yesenia's claims that open this chapter.

Variation in color is attributed to different degrees and combinations of racial mixture and it is entirely acceptable for siblings from the same parentage to be distinctly categorized, signaling that color and race are not entirely co-extensive. Both the darkest and lightest Dominicans do not claim racial purity under this system, which Gerald Murray and Marina Ortiz (2012) describe as operating under a una gota al revés ("reverse onedrop") rule, where one drop of white blood constitutes one as non-black and vice versaone drop of black blood makes one non-white. Nationality therefore subsumes any perceived racial difference by fashioning all nationals as sharing a common ancestry. 


\section{Colorism and Racism}

Given that phenotypical diversity is attached to skin pigmentation, not biological conceptions of race, some argue that social inequality in Latin America is more accurately examined through the analytic of colorism, the assignment of privilege according the shade of one's skin. Colorism is distinguished from racism by two key features: (1) the subjective application of categories leads some to argue that racism and colorism are distinct systems of discrimination; and (2) its foundation in physical appearance, not descent (Degler 1986[1971]; Harris 1952; Lovell and Wood 1998). Adopters of this perspective insist that colorism, with its nebulous boundaries and indefinite categories, lacks the analytical rigor of race. One's categorization is often relational, dependent on the persons enacting the labeling, context, and other cues. Chiefly, these observers claim that class takes primacy over color in the determination of status.

This first point of differentiation between racism and colorism maintains that social cleavages are more accurately determined by class than color. This argument holds that one of the primary means for effecting a change in color categorization is the improvement in class status through wealth or education. Investments in the racial democracy thesis by several scholars prompted them to perceive social inequalities in terms of class rather than race (see Harris 1964; Telles 2006; Wade 1993; Wagley 1965; Whitten 1974). Thus, class has been the primary lens through which social difference in the Latin American and Caribbean region has been examined. Academics have found that class mobility leads to figurative whitening, whereby dark-skinned persons are applied different skin-color labels when their class position improves or worsens. That is, they move into social positions that are otherwise reserved for light-skinned persons. The most cited case of this phenomenon 
in the Dominican Republic is that of José Francisco Peña Gómez, who, despite being, as the title of the 2016 biopic describes him, del color de la noche ("the color of the night"), gained immense popularity as the mayor of Santo Domingo and presidential candidate.

In his Introduction to Dominican Blackness, Silvio Torres-Saillant (2010[1995]) argues that Peña Gómez's victory as mayor, despite the racist and xenophobic campaign aimed at undermining his base of popular support, suggests that Dominicans regularly challenge exclusionist framings of national identity. Despite the distinctions the Peña Gómez case highlights in comparison with the US strict color line, that Blacks (and not Whites) must compensate for their complexion by mobilizing educational and financial capital suggests that even colorism is guided by a White supremacist logic.

However, analyses of actual mobility into different racial statuses over time (Andrews 2009), and through improvement in class status (Golash-Boza 2010; Flores and Telles 2012), reveal that despite some mobility within intermediate groups, achievement of white status is very rare. Further, Tanya Golash-Boza's (2010) research in Perú suggests that blackness occupies a unique space in Latin American racial ideologies, whereby blackness is understood as both color and race. Therefore, while attribution of blackness varies by context, its racial effects are mostly permanent. Moreover, Edward Telles (2012) finds that "race" and "color" are "overlapping concepts:" "color and racial identity are different ways to capture multiple manifestations of the larger concept of race" (1167). The analysis of the census and cédula categories above confirm this finding as color and race are often used interchangeably and in contradictory ways in the Dominican Republic. Conceptualizing color categories as racial categories has important implications for the 
study of anti-racist mobilizations in the region as it centers structures of inequality an analysis of how these categories are employed.

\section{Unmixing Blackness}

The activist movements that originally inspired academic critiques of mestizaje through their efforts to render visible the persistence of racism have largely adopted the academy's almost universal distrust of ideologies of mixture. As Ernesto and Eugenio quoted earlier in this chapper suggest, the Dominican government's claim that the Dominican Republic is primarily mixed race, the use of the term Indio, and other skin color categories are adopted solely to avoid the stigma of blackness. Therefore, anti-racist activists have called for the eradication of the racial ideology based on mestizaje as central to their movement.

Yet, a large part of recent Dominican Studies scholarship has challenged the idea that racial identity construction on the island is accurately captured through the lens of false consciousness. A groundbreaking issue of The Black Scholar on Black Dominican Studies, edited by Raj Chetty and Amaury Rodríguez, published in May 2015, as I was beginning the fieldwork for this project, represented this trend in the literature. The editors criticized the failure of US-based and mainstream scholarship to take Dominican engagements with blackness seriously writing, "even when investigators find a recognizable (to them) embrace of African origins and black identity there is nevertheless a strange inability to let go of narratives emphasizing Dominican self-hatred, negrophobia, and anti-Haitianism" (Chetty and Rodríguez 2015, 2). This scholarship, they argue, fails to acknowledge not 
only the complexity of Dominican engagements with blackness, but also the role of colonialism and global anti-Black racism in shaping Black identity and its study.

Considering these critiques, it took me by surprise when, during an August 2015 panel presentation in Santo Domingo about identity and culture, activists identified Dominicans' rejection of Black racial identity as the primary driver of racism. The most recent crop of Dominican Studies scholars has rejected this argument, maintaining that it promotes the idea that Dominican racial formations are exceptions to, rather than representative of, broader structures of global racial violence. That evening's presenters, along with many in the audience, were among those most imbricated in the island's growing anti-racist movement, including representatives of groups most renowned for this work, MUDHA and Acción Afro-Dominicana. With no vocal dissension from the audience, the panel discussants framed "Black denial" as a national social pathology that prevented most Dominicans from recognizing their "true" racial identity as members of the African diaspora.

As we walked to our respective lodgings, myself and two US academics I encountered at the meeting, discussed our shared uneasiness with that night's event. We saw these speakers as advocating an imperialist discourse in which US racial formations, particularly the performance and rhetoric of blackness, were constructed as superior to those most commonly adopted in the Dominican Republic. We agreed that this narrative contributed to the characterization of Dominicans as "backwards," obscuring how peoples of color are incentivized to perpetuate anti-Black racism.

Scholars of Latin America and anthropologists have been more vocal about their concerns over academic imperialism in the region. In their critique of Michael Hanchard's 
(1994) analysis of race in Brazil, Pierre Bourdieu and Loïc Wacquant argue that the continuous application of the black-white racial binary on societies outside the US effects a "symbolic violence" that restricts the production and dissemination of work diverging from the dominant perspective $(1999,46)$. In their insistence on describing Latin American racial formations as systems of White dominance over Blacks, Bourdieu and Wacquant find that scholars are failing to be attentive to the cultural and political specificities of the contexts they are studying. They contend further that the "globalization"-cum"Americanization" of US cultural and intellectual production is not sufficient to engender the parallels found between the US and its southern neighbors.

After almost a decade of silence on this debate, a new crop of researchers on AfroLatin America has revived this issue. Dominican Studies scholars (see Candelario 2007; Roth 2013; Chetty and Rodríguez 2015) have been especially wary of the uncritical reproduction of scholarship that "obfuscate[s] rather than illuminate[s] the problematics of blackness" in their reliance on worn-out narratives of "Dominican self-hatred, negrophobia, and anti-blackness" (Chetty and Rodríguez 2015, 2). Echoing Bourdieu and Wacquant's argument, they assert that scholarly production is shaped by the wider context of US academic imperialism, directly through their dependency on public and philanthropic research foundations and indirectly via their reliance on an established scholarly canon that has relied on the "othering" of Latin America and in turn justifying US imperialism in the region.

Beyond the recent revival of this decades-old argument acknowledges the role of cultural imperialism in enabling the dominance of US interpretations, new interventions go further to address the role of direct military intervention in the circulation of anti-blackness. 
Therefore, some scholars depart from the cover image of the special issue of The Black Scholar, which depicts an "unarmed black Dominican facing off the white agent of US military aggression" (Chetty and Rodríguez 2015, 9). They point not only to the "soft" power of US academic and cultural dominance, but also to the "hard" power of military might as a central element to the globalization of both anti-blackness and academic discourses of race. Thus, the cover image references the 1965 US military occupation of the Dominican Republic, the most recent of several invasions.

Considering these debates, I initially understood the panelists to be uncritically recycling imperialists' narratives about Dominican backwardness. Over time, I came to understand how anti-racist groups used this discourse to advance their claims. By framing Dominican blackness as an uncontestable fact, Dominicans challenge the ways the dominant narrative of mestizaje makes blackness invisible by including it only as an element in mixture. Doing so, Dominicans like Yesenia point to their bodies as incontrovertible material evidence of their African ancestry, A mi se me ve la negritud en la nariz porque mi nariz es grande. Se me ven en el grososo de mis labios porque tengo los labios grososos, como dicen, carnosos ("You see the blackness in the nose because my nose is big. You see it in the thickness of my lips because I have thick lips, as they say, meaty.") On multiple occasions, activists drew on physical features that were regularly racialized to distinguish non-Europeans, including noses, lips, hair texture, and body type (e.g., hips, buttocks). By reading her body in this way, Yesenia asserts that the body constructed as a fact can challenge the practices of erasure aligned with mestizaje.

Although the manner in which activists understand the relationship between race and the body reifies racial difference, phenotype has always been at the center of racial 
construction and classification. Peter Wade, an eminent scholar of race in Latin America, writes that "bodily appearance is often taken to be the raw material on which concepts of race are built" $(2002,4)$. However, he reminds that the body is not pre-discursive and therefore cannot be experienced outside racial meaning. Even though racialization is often practiced by racially categorizing bodies, especially in Latin America where skin color is often the linchpin of racial meaning, most anti-racist scholars argue that tying race to the body produces an essentialist conceptualization of race that defines certain qualities as inherent to different races. Anti-essentialists find that associating race with such unchangeable qualities obscures its historically and culturally variable nature. This view of race also precludes efforts of individuals to transform and reshape racial categories and meaning.

For Dominican anti-racist activists, however, this framing of race is particularly useful as it directly contradicts how race is understood under mestizaje which, in theory, argues that all nationals share a mixed racial identity regardless of phenotype. While references to phenotype are a regular part of Dominicans' daily interactions, phenotype is not the basis of social stratification or the formation of social groups. Therefore, in contrast to this dominant understanding of mestizaje, the privileging of a set of racialized phenotypical markers in the construction of Black identity on the island offers a sense of facticity around race that frustrates any effort to disassociate oneself from blackness.

Alicia, one of the central leaders of Reconoci.do, spoke to me at length about how she had developed a positive association with blackness. Like Rosa, who spoke about her struggles to wear her hair natural in Chapter 4, Alicia noted that the positive associations with blackness she was raised with were an exception to the rule. Growing up, she 
explained, her father would say, el único blanco que tengo es debajo de los pies ("the only white I have is underneath the feet.") Identifying this as una expresión racista ("a racist expression"), she explained that it reversed the prevalent hierarchies of Whiteness and Blackness as she and her family experienced them in the Dominican Republic. Moreover, they rejected the common practice of Blacks in the Dominican Republic to claim racial mixture to improve their social standing. For Alicia, appeals to racial mixture most often minimized one's blackness, even when blackness was an acknowledged as a constitutive element of that mixture. Her experience challenges the idea that all Dominicans are raised to denigrate blackness and that mestizaje is not embraced by all Dominicans.

In another istance, in a two-day workshop titled ;Yo me parezco! ("I look like!") designed to educate youth ages 9 to 13 about local and global Afrodescendant leaders, Lissette, the local artist who organized the event, guided the five girls through the creation of self-portrait collages. The aim of the exercise was to provide positive images of blackness that can combat both its primarily negative associations and thereby transform participants' self-perception. The first day was primarily dedicated to learning about prominent Afro-diasporic figures, including the Obamas, Chimamanda Adichie, and local Dominican-Haitian activist Sonia Pierre. At one point in the workshop, Lissette projected a photograph of Angela Davis to the group. In the Dominican context, few would consider her to be Black, with her highlighted blonde hair and light skin color that would be classified as trigueña (wheat-colored). Yet, Lissette posited rhetorically, ¿Ella es afrodescendiente, verdad? ("She is an Afrodescendant, right?") She argued that despite Davis' skin and hair color, the shape of her nose and kink of her hair were sufficient evidence that she is Afrodescendant. While within mestizaje Davis' phenotype signals 
mixture, in Lissette's evaluation of Davis' phenotype, she determines her identity exclusively based on those features racialized as Black. In addition, within the dominant White/Black binary system in the US, someone like Davis would typically be classified as Black.

For those who have lent their voices to social constructionist arguments, the corporeal framings of blackness used by Dominican activists are uncomfortably resonant with the essentialist framings of race that have been discredited as exclusionary by the late$20^{\text {th }}$ century wave of postmodernist critique. Furthermore, the latter intellectual camp finds identity politics to be ahistorical and reductive of the complex ways individual and group membership evolves over time.

Most of the contemporary social science literature adopts the social constructionist perspective that sees race as the product of context-dependent struggles for power (see Omi and Winant 2015[1986]). The social construction perspective on race forwards an antiessentialist approach to identity, which often decenters the body as a factor in the construction of racial meaning. However, some scholars have argued that the overwhelming tendency to displace the body in examinations of racialization obscures much of the lived experience of racialized persons and how bodily representation and performance are often critical to shaping racial discourse and practices. "Strategic essentialism" illuminates how provisional identities can serve as tools for coalition building and consciousness raising, without precluding internal critique and future remodeling of a group's identity (see Spivak 1988). While cementing the grounds for collective struggle, strategic essentialism avoids the pitfalls of ahistorical and universalist coalitions that silence internal differences and debates. 
To be sure, Lissette's and Yesenia's location of blackness within the body is a narrative capable of countering mestizaje, which functions to eliminate phenotype from considerations of race. Under mestizaje, race is tied to nationality and the nation is imagined as a family that shares a singular racial composition. Lissette's and Yesenia's emphasis on the physicality of racial difference also points to the particularity and inevitability of their lived experience as racialized persons. This is a powerful argument within a state and societal milieu that is highly conscious of color variation, while maintaining that racial difference and racism are anomalies.

\section{Transnational Blackness in Rap}

Locating blackness in phenotypical features builds on the existing practice of reading color and phenotype to categorize individuals under the color continuum model and provides a facticity to racial identity that supports the creation of an activist movement organized around blackness. By pushing an alternative reading of a person's phenotype that sees Black features as leading not to a mixed-race, but a Black identity, activists work toward broadening the base of their movement beyond the Dominico-Haitian population and the limited cadre of Dominicans without Haitian descent who have taken up this cause. Although blackness offers fewer opportunities for the expression of a variety of social positions and experiences through the proliferation of color categories, to date, the color system has not been indicative of a collective social consciousness or shared experience.

By contrast, blackness provides a discourse that allows Dominico-Haitian activists to translate their social experience to their own communities, dark-skinned Dominicans who 
they argue share their social experience, and international communities that have provided indispensable financial and intellectual resources.

As Eugenio's reflections on being called moreno summarized above indicate, claiming blackness is a choice rather than an obligation for these activists and many, like Eugenio, frame this choice as a political one, situating their own coming-to-consciousness within transnational histories of anti-racist struggle and resistance that transcend national boundaries. Locating blackness in their bodies also counters state-sponsored narratives around blackness that most often confine blackness within the past. They are most seen in the presentation of colonial-era presentations where costumed dancers perform traditional choreography attributed to Afro-diasporic populations. Beyond those practices preserved from the distant past, state-sponsored public events rarely embrace contemporary cultural practices associated with the African diaspora, such as rap and dembow.

One source of criticism of the rise of these musical genres is that they are often associated with Dominican transnational migration, particularly to the United States. Whereas these connections abroad are recognized as important to social mobility, Dominicans abroad are simultaneously associated with drug trafficking, urban violence, and blackness, given their racialized status (see Itzigsohn 1999) and social anxiety over the growing popularity of African cultural musical genres such as reggaeton, rap, and dembow. In 2012, an article in the Listin Diario posed the question of whether dembow, the popular musical style traced to Jamaica with roots in reggaeton, could even be considered music. Citing a musician of merengue, a traditional musical genre that is championed for its national patrimony (see Austerlitz 1997), the article relays social perceptions of dembow as peligroso para la salud, "a danger to one's health." As with Dominican rap, this 
emergent style of music is criticized as being violent, vulgar, and devoid of artistic merit. As many of its artists descend from the island's urban and poor sectors, these critiques are fueled by racist and classist prejudices regarding the popular cultural productions generated from these communities.

While the appeal of rap and other urban genres of music was mixed among antiracist activists, founding members of Reconoci.do utilized the genre to disseminate their message and to engage members in activities that were not overtly political. Recreational activities that included rap and other musical performances, dance, food, and other forms of entertainment were key elements in efforts to maintain and grow the organization. However, members' composition and performance of rap often interlaced political themes within more popular messages of love, sex, and money.

To ensure the success of the musical group associated with the movement, members were selected via a 2012 competition in which the social content and performance style of activists were evaluated by the Reconoci.do membership. The musical group was an extension of the organization, performing under the same name. These performances took place not only at events specifically organized around themes of anti-racism and human rights but also festivals throughout the eastern district of La Romana. During one regional meeting in the area, I visited the makeshift recording studio where members of the organization hoped to record an album of their more socially conscious music and use the proceeds to support future organizing efforts. Although the capital for this initiative was never realized, this group and others continue to perform a repertoire of songs relating experiences of discrimination as a racialized and undocumented group. 
One such song, Junta ven y dime ¿Cuál es mi nombre? ("Junta Come Tell Me, What Is My Name?"), articulates a demand that the state admit its culpability in engendering the suffering of Dominicans of Haitian descent vis-à-vis the institution of the

JCE. The second verse recounts the effects of these measures:

Esta historia es de una chamaca nacida en la Romana, que tiene cédula y pasaporte, pero ya no es dominicana. Porque la Junta y el estado quieren limpiar la raza, eliminando un grupo de negros de ascendencia haitiana. Yo también soy dominicano, pero me siento discriminado, porque el estado me ha dejado con el corazón destrozado, por decir que soy extranjero en la tierra que murió mi abuelo.

[This is the story of a girl born in the Romana, who has an ID and passport but is no longer Dominican, Because the Junta and the state want to purify the race, eliminating a group of Blacks of Haitian descent. I too am Dominican, but I feel discriminated because the state has left me with a broken heart, by saying that I'm a foreigner in the land where my grandfather died.]

Diverging from other songs, such as Sueño con eso ("I Dream of It"), which is performed in the fast-paced style characteristic of rap, the lyrics excerpted above are sung in a slower R\&B style overlaid with a twangy guitar track, the signature of the Dominican genre of bachata. This music contributes to the emotional story of many of the movement's members who have their citizenship revoked. While situating their critique in local dynamics, the group draws on rap's themes of expressing lived realities of discrimination and loss, including death of close ones. Although, the death referenced here is not one caused by the overt police or gang violence that is predominantly referenced in many rap songs, but presumably that of the exploited Haitian cane cutter. 
When I asked one of the group's members, Carlos, why he thought music was an integral strategy of furthering the social goals of the organization, he responded that beyond music being an important outlet for his feelings, success in the music industry allows him to "convert" a large population both nationally and internationally more easily than traditional methods of activism. Music was ubiquitous during the group's public protests, helping to animate the crowd and fostering a sense of shared group identity through the memorization and performance of lyrics, many created by the group itself. Activists built upon both the popularity of rap among youth, but also its prevailing reputation as a socially conscious genre employed by African Americans to articulate and protest their marginalized social condition.

In the song Sueño con eso, Delma, the artistic name of the Reconoci.do activist who performs the song, expresses his desire to engage in the tradition of rap as protest music. He raps:

Sueño que el pólice no mata a la gente, cuando sospecha que es delincuente Quiero que el mundo pare de girar, que se detenga y se ponga a pensar, que cada humano es muy especial. En esta tierra nadie es ilegal.

I dream that the police don't kill people when they suspect they are delinquents. I want the world to stop spinning, for it to halt and begin to think That every person is very special. In this land no one is illegal.

Delma's use of pólice, the Hispanicized pronunciation of the English word police in lieu of policia, intimates his engagement with conversations about police brutality that have 
been the focus of US-based anti-racist movements in recent years and the performer's desire to connect social issues in the Dominican Republic with broader anti-racist struggles. This desire is further intimated in the song's title and chorus, "I Dream of It," which alludes to Martin Luther King's "I Have a Dream" speech. Whereas King's speech calls for freedom in New York, Mississippi, Georgia, and Tennessee, this song calls for equality among different nationalities, including Iraqis, Colombians, and Venezuelans.

Activists' use of rap contrasted with state-sanctioned images of Black cultural expression, which most often take the form of folkloric dances. Such dances were often performed at the weekly concerts sponsored by the Ministry of Culture, attended by locals and tourists alike. A popular variation of the costumes typically worn in these performances is a wide ankle-length skirt for the female dancers that they fan in the air throughout the performance. Male dancers typically wear crisp-cotton guayaberas accented with a bright handkerchief and/or a straw hat. By contrast, by embracing the urban cool aesthetic associated with rap and expressed in their self-styling in the baggy pants, chains, and straight-brimmed caps associated with US urban culture, Dominicans construct a more modern image of blackness. This assertion of modernity contrasts with the narrative of mestizaje which figures blackness as amodern. Several scholars have recently written on the folklorization of blackness, contesting earlier claims that failed to acknowledge the existence of any images of Black culture. Rather, they show that blackness often exists at a safe distance —in the past (see Thomas 2004; Godreau 2015; Perry 2016). 


\section{Films and Funding}

The shelf in Alicia's office where she stored the DVDs she used for these activities only held films produced in the US. Many of the titles, mostly unauthorized copies bought on the tables set up outside La Sirena on Avenida Mella, were about US civil rights struggles. In one gathering in a community center in the eastern municipality of Guaymate, Alicia referenced Selma to argue for the importance of the Dominico-Haitian voting bloc. Although the film's narrative centering on the 1965 march for Black voting rights in the US south is both geographically and historically removed from the contemporary struggles of Dominicans of Haitian descent, Alicia insisted on the film's relevance to the youths' own struggles against codified practices of discrimination.

Moreover, the organization's ability to purchase these films is to a certain degree made possible by funding raised by the US-based Dominican diaspora groups such as Border of Lights and We Are All Dominican and other US-based organizations such as the American Jewish World Service. Often, these funds supported specific areas of action and thus had a role in shaping the organization's agenda. Maintaining visibility to an audience abroad was a main concern of the group's leaders. At a May 2014 meeting to discuss recent state efforts to address the crisis of documentation, the head of Reconoci.do opened the dialogue emphasizing that the Dominican Republic had become as renowned for its human rights abuses as it was for its tourism. After the meeting, when I asked how I could contribute to the organization, she emphasized that maintaining interest in the US was how I could make the biggest contribution. Her statements to me and the majority Dominican audience emphasized the international arena as among the most important focuses of organizing. 
Rather than support the various calls for a tourism boycott, activists have instead encouraged visitors to come to the island. In a letter drafted by public university students and a retired professor that gained several supporters, the Colectivo Isleño (Island Collective) argues that the boycott would disproportionately impact Dominicans of Haitian descent who frequently work in tourism and "would be first to be fired by the bosses if the number of tourists were to decline." Alicia, a high-ranking member of Reconoci.do, seconded this stance when a US-based academic and activist consulted her as to whether a conference should be held on the island. Rather than cancel, she told him, they should incorporate a space for dialogue with those affected, whose lack of legal documentation makes it difficult to travel outside the country.

While activists on the island were grateful for the support of diaspora communities and organizations abroad, at times, this resource disparity became frustrating. During the planning for a demonstration marking the second anniversary of the passage of the TC 16813, Alicia was concerned about the limited availability of funds to support the attendance of the majority of those affected who live in rural batey communities outside the capital area. Comparing the difficulties she had accessing funding with the relative privilege of the Dominican diaspora, she lamented a situation where Dominican New Yorkers would possibly have a larger turnout than those affected by the ruling. Her feelings expressed a sense of disempowerment around the fact that those who have the most at stake in the future of Dominican documentation policies were less equipped to publicly voice their complaints. 


\section{Conclusion}

Contemporary struggles over the representation of blackness indicates the complexity of meanings tied to blackness. Latin America, where, as Peter Wade (1993) puts it, the boundaries of Black identity are disagreed upon, is fertile ground for examining how struggles over racial identity unfold. To be sure, the scarcity of racial mobilizing under the rubric of blackness furnishes ample opportunity to shape the construction of an image of blackness on the national stage. However, this same void provides little precedent for activists. Faced with a national ideology that often undermines racial difference, the analysis of census and cédula categories presented here provides important insight into how the state has defined and shaped these categories. Importantly, it shows that color and race overlap in Dominican constructions, challenging claims that colorism can be distinguished from racism.

Further, in the absence of a well-formed and didactic history of organizing around either race or ethnicity, Reconoci.do's deployment of rap forms part of a broader trend of turning to the US for cultural and material resources in this and other anti-racist struggles. While the US is only one of the national contexts activists draw on in forming their representation of blackness, the ubiquity of US cultural imports such as music, movies, and print media earned it significant influence among the youth who form this movement. This market dominance, paired with the fact that the US receives most of the country's emigrants ensures, that the US has a significant influence over the ways blackness is represented in the Dominican context. The available materials with which to organize the regular cineforos, screenings of films and their discussion, reflected this dynamic. These struggles unfold as the state has increasingly adopted a color-blind position that furthers 
mestizaje's "silencing" of race (Rodríguez-Silva 2012) through attempts to eliminate the visibility of both race and color in the census and cédula. These documents communicate powerful messages to the public about racial identities and hierarchies that, in turn, lay the ground for anti-racist claims.

While the activists I worked with in the Dominican Republic employed discourses and representations of blackness that originate in the US, activists and other adopters of Black identity drew from a broader range of influences. Genres such as dembow mentioned above and reggae were frequently promoted by racially progressive sectors. Moreover, the power of US representations of blackness is directly connected to the prevalence of popular and academic resources on the island. As Steven Gregory (2014) argues, globalization has opened opportunities for Dominicans and Haitians in the Dominican Republic. He finds that Dominicans and Haitians alike utilize a "sampling of African American, Rastafarian, and other cultural practices and identities as both an exercise of a diasporic imaginary and a modality of practice through which they subverted, complicated, and contested the conflation of Haitian identity with stigmatized blackness" (262). His larger examination of reveals globalization as an uneven process which unfolds according to historically produced political and economic inequalities. This line of argument can be extended to Dominicans' unequal access to US material and intangible culture.

In Latin American Studies, the question of how to translate and deconstruct alternative forms of racialization has been a subject of considerable interest. In the Dominican Republic, these questions have led to uncertainties about whether emerging narratives of Dominican blackness evidence neo-imperialist interventions that "universalize" the racial formations found in the West, mainly the US (Bourdieu and 
Wacquant 1999). However, as Chetty and Rodríguez have argued, the power relations that engender the supremacy of the US academy and its broader cultural productions transcend any individual researcher, university, academic association, or discipline. Furthermore, it is not only the seduction of the West's resource-laden publishing houses and movie studios, but also its military might that transmit its image across the globe. Still, missing from this dynamic is the ways that those caught in these crosshairs maneuver within broader fields of power toward more liberatory ends. Clearly, as Edward Bonilla-Silva (2004), Nancy López (2013), and others have argued, even though exchanges of meaning-making are not inextricable from the broader contexts of power in which they take place, they are not unidirectional. To be sure, the Dominicans who decry their society's racial dysmorphia are gesturing toward the globality of racism and anti-blackness, toward which scholars have been pointing. The contours of their contestation, dominated by US contributions to the global African diaspora, mirror the asymmetries of power pinpointed by Bourdieu and Wacquant (1999) and Chetty and Rodríguez (2015). Despite their limitations, activists are attached to these narratives of blackness precisely because of their alignments with power, as they attempt to gain visibility under state-sponsored discourses of mestizaje and its attendant politics of non-racialism. As their efforts have shown, blackness provides an already-formed language through which activists may articulate experiences of racial marginalization when the framework of mestizaje only offers invisibility. 


\section{CONCLUSION}

[L]os años pasarán y las oportunidades que perdemos, no las vamos a recuperar. Si bien es cierto, podemos decir que un documento no tiene ningún valor en sí mismo, sino el valor que le damos como sociedad. Pero [en] una sociedad donde el acceso a todos los derechos pasa por la vía de un documento se convierte imprescindible para el desarrollo de una persona.

[Y] ears pass and the opportunities that we lose, we won't recover. Although it is true, we can say that a document has no value in itself, but the value that we give it as a society. But, [in] a society where access to all rights is via a document, it becomes indispensable for the development of a person.

-Franklin Dinol, Inter-American Court on Human Rights, February 26, 2018 ${ }^{53}$

\section{The Continued Fight for Citizenship}

Regardless of whether Haitians possess official Dominican documents, as suggested by Dinol's words the impact of the denationalization policies on DominicoHaitians will follow them for the rest of their lives. As highlighted in the analysis presented here, many faced obstacles in accessing their documentation as early as 2005 , meaning that by the 2014 reform, their lives and dreams had been deferred for almost a decade. For many, the policy came at a turning point in their lives as their appearance at the Junta to request the copy of their acta was precipitated by a job offer, pending marriage to a foreign spouse, a scholarship to study abroad, their recruitment on a baseball team, or registration in a university. They are persons whose social and economic mobility was hard-won from

\footnotetext{
53 Comisión Interamericana de Derechos Humanos, February 27, 2018. "República Dominicana Cumplimiento decisiones SIDH” https://youtu.be/VSLk8F0M_34.
} 
the destitution and social isolation of the bateyes. Afectados (those affected by the sentencia) use many phrases to describe their precarious juridical condition: muerte civil (civil death), genocidio civil (civil genocide), and vidas suspendidas (suspended lives). The Reconoci.do movement became a place where those affected could redirect their energies and find employment by becoming professional research assistants, promotores, and social workers, but this is the story of only a fraction of the more than 200,000 impacted by the ruling. Instead of going to college or technical school, some, artesania (arts and crafts), or food in their homes or in the streets. Some followed in their parents' steps and worked cutting caña under someone else's name; some women sought the protection of a partner or resorted to sex work; and still others found no alternative to their broken dreams. Stories of persons contemplating or attempting suicide, like the one discussed in Chapter 3, were common among those living the consequences of this policy. I sometimes refer to this group as the generación perdida, the lost generation, given the enormous amount of promise and grand plans stalled by the sentencia. Their collective movement gives me hope that they will be able to create the society that they envision.

However, the way the state has fulfilled this process, through the creation of the double registry, remains an obstacle to Dominicans of Haitian descent's full exercise of citizenship. As alluded to in Chapter 3, the documents of Group A are relocated to a separate book in the national registry (birth certificates are referenced by a series of numbers indicating the book and folder where the original is located). To "transcribe" this document, the JCE petitions the civil court to nullify the original birth certificate before creating a new one in the Libro de Transcripción. The new document is accorded a new location ID, referencing the year the new acta was emitted. This process generates several 
issues. First, when one tries to use this new document, it appears as if one was recently born and given the new registry. Second, this change in registry requires changes in one's national ID and any property or vehicle registered under the previous number must be reregistered under the new number. Third, as previously discussed, the law governing the return of these documents dictates, a las que en el pasado se les haya expedido cédulas de identidad y electoral sean dotadas del mismo documento con su numeración anterior ("to those that in the past have been issued identity and electoral certificates are endowed with the same document with its previous numeration") (Ley No. 169-14). Finally, the creation of this new registry is one of many extralegal mechanisms the government has employed to infringe on the rights of Dominicans of Haitian descent even if the scope of its impact is unclear.

By comparison, however, those in Group A are the fortunate ones. Since 2014, legislation that offered temporary residency to both Haitian immigrants and unregistered Dominicans of Haitian descent (Group B) through the PNRE has left them in limbo. The current procedure to apply for permanent residency, designed for immigrants, is impractical for those born in the Dominican Republic, who lack the necessary foreign citizenship documents to complete the process. This group, lacking both Dominican and Haitian citizenship, is stateless. When I visited the Dominican Republic in October 2016, a leader of Reconoci.do informed me that the government was discussing ways to address these issues but had once again failed to consult the affected communities. During the February 2018 meetings of the International Court of Human Rights, petitioners representing denationalized groups asked that they be consulted in future measures, indicating that they had not been invited to join conversations. In these same meetings, the 
Dominican delegation complained that many who entered the plan had not picked up their documentation, suggesting either its lack of value, mistrust of the state, or, as I heard from many activists, the refusal of Dominicans of Haitian descent to carry a document that designates them as Haitian nationals. Beneco Enecia, representing a group of Dominican civil society, proclaimed that at that time, 133,760 persons in Group A or B had not received their documents and remained stateless. At the time of the publication of this document, this rumored plan has yet to be unveiled. Equally troubling is the lack of an adequate challenge to the wholesale elimination of birthright citizenship for those born after the implementation of the 2010 constitution, which changed citizenship from jus soli to jus sanguinis. Therefore, the children of non-citizens remain blocked from obtaining Dominican citizenship. Now, this generation is less than eight years of age and the effects of these policies will become more visible when its members reach eighth grade and will need documentation to continue their studies. In the meantime, the Ministry of Education may change the current regulations and require documentation earlier. It appears that citizenship has been permanently transformed in the Dominican Republic.

\section{Citizenship and Race in the Dominican Republic and Beyond}

Franklin Dinol, a member of Reconoci.do offered the comments above at the $167^{\text {th }}$ session of the Inter-American Court of Human Rights held in Bogotá, Colombia. This statement reflects the current status of citizenship for Dominicans of Haitian descent in the Dominican Republic. At the time of completing this manuscript, most of the estimated 55,000 persons designated as Group A by law 169-14 (those previously registered) have

received their documents reinstating their rights. However, as Dinol's statement above 
illustrates, although access to documentation has been a central demand of the Reconoci.do movement, its concerns exceed the desire for documentation alone.

To that end, Dinol's comments highlight a fundamental tenet of the scholarship on citizenship — that citizenship exceeds its formal dimensions to include cultural and social dimensions which reflect the race, gender, and class dynamics of a given society. Dinol seems to argue that in many senses, these more informal dimensions are more important. This project has examined how these racial, gendered, and classed and citizenship dynamics unfold in the Dominican Republic within a unique racial and national history that has led to the exclusion of Haitians as both racial and national others. Through ethnographic fieldwork with Dominico-Haitian activists, those most embroiled in contemporary debates about race and dominicanidad, this dissertation has found that the overlapping of race and nation vis-à-vis mestizaje engenders the exclusion of racial others as national others that is at the root of the recent citizenship crisis. In addition, this project offers several contributions to the Dominican, Latin American, and citizenship studies.

Since its conception, this project emerged in response to the recent call by Dominican Studies scholars to reinterpret Dominican blackness (see Mayes et al. 2013; Chetty and Rodríguez 2015; García Peña 2016). The scholarship that has formed part of this new wave has almost exclusively drawn on literary and ethnic studies with little ethnographic documentation of how Dominicans on the ground are working toward and envisioning antiracist futures. This study not only serves to close the scholarly gap in this field by focusing on how contemporary Dominicans outside the literary canon center blackness within their collective organizing, but also sheds light on the experiences of Dominicans of Haitian descent, addressing a significant blind spot in our knowledge. The 
lack of scholarship in this vein is especially troubling given the centrality of Haiti in analyses of race in the Dominican Republic. This oversight is reinforced by what Nina Glick Schiller and Ulrike Meinhof (2011) identify as methodological nationalism, or the tendency of researchers to reify nation-state boundaries in their research. Unwittingly, it may also reinforce stereotypical images of Haitians as passive victims of racial exclusion.

By centering the experiences of Dominicans of Haitian descent, this research applies a new perspective to the project of untangling the perennially knotted threads linking dominicanidad, anti-haitianismo, and anti-blackness. Much of the existing scholarship contends that dominant framings of dominicanidad are founded on antiblackness and anti-Haitianism (see Wucker 1999; Sagás 2000). Further, they find that Dominican understandings of blackness and Haitianess overlap in ways that preclude any meaningful engagement with blackness not made vis-à-vis Haiti.

To that end, Chapter 2 of this dissertation provided a historical accounting of how Haitian immigrants and their descendants have accessed citizenship. It found that the sugar industry was the key factor in questions of Haitian integration and access to formal citizenship in the Dominican Republic. For much of the $20^{\text {th }}$ century, Haitians' labor on sugar plantations determined their ability to work, reside, and raise families in the Dominican Republic. Eruptions of racial and xenophobic violence in the 1937 border massacre and later in the Balaguer government's deportations targeting non-cane workers in the 1990s solidified the social and economic marginalization of Haitians. These actions made it clear that bateyes were the only places where Haitians would be protected in the Dominican Republic. 
The sugar industry was also charged with enforcing the bilateral accords that regulated Haitian labor migration, often violating these agreements by refusing to return migrants after the harvest. Sugar and the state were so closely entwined that during much of Trujillo's rule they were one and the same. According to written and oral histories, cane worker identity cards, or fichas, were often the only documentation provided to the largely Haitian labor population. Because of the longstanding relationship between the state and sugar, the crisis in the sugar industry in the 1980s and 90s. generated the current citizenship crisis. This historical overview exhibits how the prevailing construction of haitianidad, and Haitians' access to citizenship in the Dominican Republic, have been overdetermined by the country's reliance on the monocrop sugar economy. This analysis helps situate the recent citizenship crisis within the broader field of vision offering a more complex reading than that possible from the perspective of anti-Haitianism alone.

The new techniques for Haitian incorporation necessitated by the collapse of the sugar industry were the focus of Chapter 3. An examination of the Plan Nacional de Regularización de Extranjero, aimed at integrating the previously undocumented population, and the shift from jus soli to jus sanguinis shows how they failed to meet their purported aims of radically transforming Dominican citizenship into a more streamlined, modernized, fair, and just system. Rather, these reforms exacerbate the racial and gender inequalities outlined in Chapter 2. Additionally, this chapter offered an alternative reading of contemporary citizenship practices in the Dominican Republic, arguing that they are centered in inclusion rather than exclusion. Utilizing Nicholas De Genova's concept of the "spectacle of illegality," I show how the processes around these new subjectivities serve as "spectacles," drawing attention away from the law as the "site of exclusion" and thereby 
rendering the migrant/seeker of citizenship "underserving" and ultimately, illegal (De Genova 2013). These spectacles thereby legitimate the protracted history of irregular and inconsistent citizenship policies that have a discriminatory impact on Dominico-Haitians.

Moreover, this research has shown that citizenship and documentation have become more important in the Dominican Republic. An overview of the treatment of Dominican citizenship from the beginning of the $20^{\text {th }}$ century to today shows an opposite trend from that identified by scholars of globalization and transnationalism, including those who applauded the Dominican Republic's early efforts to extend rights of citizenship to the Dominican diaspora. To that end, this project calls for a reevaluation of the significance of transnational citizenship (see Duany 2008[1994], 2011; Glick Schiller 1999; Itzigsohn et al. 1999; Levitt 2001; Sagás and Molina 2004; Sørensen 1996). Rather than understanding the integration of the Dominican diaspora as portending the decline of citizenship or even as an expanded citizenship philosophy, this work suggests that transnational citizenship is consistent with the racialization and gendering of citizenship under mestizaje. Alongside the previous chapter, this section of the dissertation addressed the development of anti-Haitianism, dominicanidad vis-à-vis access to citizenship, and racialization.

Chapter 4 mapped out the relationship between Haitianess and blackness. This chapter asked, what, if any, are the possibilities of articulating blackness beyond or outside Haitianess in the Dominican Republic? To that end, it centered the nation's growing natural hair movement as an increasingly organized and visible sector organizing to create a space of Black aesthetics and subjectivities within Dominican popular culture. None of the most prominent leaders of the natural hair movement identify as having Haitian descent. 
However, their experiences show that blackness and Haitianess are both signified in natural hair. Although many of those I interviewed and engaged with at natural hair events framed their decision to wear their hair natural as resistance, others identified a trend towards the commercialization of natural hair that may dilute its radical potential. Some, such as AfroDominican activist Carmen and Dominican of Haitian descent organizer Alicia, found that natural hair was more easily accepted when aligned with middle-class and patriarchal aesthetics that demand that one be "worked on and worked up" (Tate 2009, 25). Thus, those who cared for their natural hair outside of these spaces of consumption enjoyed both less acceptance and less access to the language of resistance. This chapter also confirmed that blackness is often signified as Haitianess in the Dominican Republic. However, it pointed to fissures and disruptions within the overlapping layers of Haitianess and blackness, particularly as some middle-class sectors lay claim to Black identities. As such, they draw on transnational natural hair fashions and move away from associations from blackness with Haitianess.

Focusing more closely on the work of Dominicans of Haitian descent who organize as Reconoci.do, Chapter 5 examined how these activists articulate their identities in their anti-racist and anti-xenophobic organizing. This final chapter centered state-based racial narratives as promoted by the Dominican census from 1920-1981 and the cédula skin color category until its elimination in 2014. I argue that the census serves as an example of "state speech" (Goldberg 2001) through which the state not only articulates but promotes racial knowledge (Loveman 2014). Census results reveal several aspects of official racial narratives. First, they show that race and color are often used interchangeably in the Dominican Republic, suggesting that color and racial systems are not distinct concepts, but 
that color maps onto race. This finding challenges the tendency of scholars to frame racism and colorism as distinct social phenomena that allow for greater social mobility (Hernández 2013). Moreover, it undermines the tendency to idealize Latin American racial formations as benign, when compared to the United States. Second, these census results confirm Ginetta Candelario's (2007) finding that the Dominican racial ideal is best captured by the indio, an intermediary mixed-race category between Black and White. Finally, the census belies a deeply engrained racialization of Haitians at the national level through the association of Haitians with "physical difference" in the 1981 census question.

However, Reconoci.do's activism reflects a more critical approach to mestizaje than that advanced by state-based narratives. Instead, the latter promote accusations of Dominicans' anti-blackness and Black denial that much of the recent Dominican Studies scholarship has challenged. To that end, activists portrayed Dominicans as not being able to see that they are, in fact, Black. In Chapter 5, I asked why Dominican activists have chosen to advance these narratives that many scholars (see Chetty and Rodríguez 2015; Torres-Saillant 2001; Ramírez 2018; García Peña 2016) have found counterproductive to challenging racism in the Dominican Republic as they "obfuscate rather than illuminate" racial dynamics in the country (Chetty and Rodríguez 2015, 2). Moreover, activists reproduce these narratives of Black denial despite their very being evidencing that not all Dominicans reject blackness. Therefore, while some scholars like Peter Wade (2005) have called for a "rethinking" of mestizaje as a potentially progressive racial ideology, the historical coupling of racial and national identity through mestizaje has significantly contributed to the inability of Dominicans of Haitian descent to claim belonging after several generations. 
Many members of Reconoci.do reverse the practices of racial interpretation that often ascribe mixed-race identity to anyone deemed to exhibit one drop of whiteness. Rather, they rely on an interpretation of racialized bodily features that ascribe blackness to the person in question. Though potentially essentialist, this method lends corporeal weight to racial identification that is lost within the dominant mixed-race system, in which individuals fall within multiple and sometimes contradictory categories. While this approach to race is potentially essentialist in that it locates racial identity within a set of stereotypical physical features, attribution of blackness is not the endpoint of racialization for activists, but the starting point. According to the activists I interviewed, one's blackness is developed and fulfilled through a process of consciousness-building that involves commitment to social action, the pursuit of alternative social histories, and the forging of diasporic links. Much of Reconoci.do's work outside of the public forum involves the development of this consciousness. To that end, activists employ not only the narratives of blackness outlined above, but diasporic resources that provide the materials to challenge and supersede statist racial scripts.

However, the resources available to activists are governed by both migration and funding circuits. Access to US cultural materials, due to (1) a long history of US involvement in the Dominican Republic, (2) the attendant migration to the US, and (3) the proximity of the territories, and (4) the general unevenness of globalization, has resulted in the predominance of US influence in the organization. Further, much of the funding derives from US and European-based religious organizations. In their pursuit of this funding, the leaders of the organization must frame their problematic in terms intelligible to international audiences. To that end, their racial discourse often reflects understandings 
more traditionally attributed to the US context. Therefore, the cultural materials employed in their struggle are inherently shaped by these dynamics.

In the end, this analysis set out to map the relationship between dominicanidad, haitianismo, and negritud in the context of the recent citizenship crisis in the Dominican Republic. It has done so through the experiences of those who are paving the way toward anti-racist futures. Their experiences show that the co-articulation of race and nation in mestizaje remains a primary challenge to citizenship for racialized persons. However, emerging efforts to challenge anti-blackness from a wide array of Dominicans have the potential to exclude Haitians who have been economically and socially marginalized by adopting a politics of Black respectability, especially a middle-class aesthetic. The natural hair movement's rise may result from the disentangling of blackness from Haitianess, an effort that Dominicans of Haitian descent have supported through the Reconoci.do movement. However, divorcing blackness from Haitianess decenters Haiti’s revolutionary legacy in the history of diasporic blackness and through uneven transnational circuits turns toward articulations of blackness often derived from the US.

This research has broad implications beyond the Dominican context. Much of the research on citizenship and illegality has focused on the Global North with scant attention to the ways migrant-sending countries traditionally integrate immigrants and their descendants. Much of the academic literature on Latin America has recently begun to turn to race as a major axis of organization, but few have looked at race as articulated alongside citizenship despite rich histories of migration to places like the Dominican Republic. At the urging of illegality theorist Nicolas De Genova, this work shifts its focus from the individuals rendered "illegal" to the processes that produce the condition of illegality (De 
Genova 2002, 423). Centering the citizenship projects of the Dominican Republic adds to this growing scholarship on illegality, showing how colonial racial projects are reproduced as citizenship projects.

To be sure, the development of alternative citizenship projects in the Dominican Republic proves the necessity of such an examination of how illegality is being produced outside of US and European contexts. While this analysis also contributes to the mapping of how illegality is racialized, it shows how its articulation is governed by the local and regional context, including histories of migration, modes of migrant incorporation, and racial scripts. By suggesting that the expansion of research on citizenship outside the Global North must be attentive to these dynamics, this research suggests that in the Latin American region, the ideology mestizaje still plays a central role in determinations of belonging. Conceived by prominent Latin American intellectuals in the early $20^{\text {th }}$ century as a national and racial philosophy, mestizaje lays the ground for the overlapping exclusion of racial others as national others and vice versa through the racialization of national difference. Given that the Dominican Republic is just one of many nations organized around mestizaje, this project's findings suggest that mestizaje may pose similar obstacles to foreign-origin groups throughout the Latin American and Caribbean region. As the activists in this project suggest, the persistence of mestizaje as the dominant racial narrative presents a fundamental obstacle to the ability of foreign-origin groups to access citizenship rights. Beyond the Latin American context, this project documents the reversal of birthright citizenship as several political actors in the US and elsewhere have considered similar measures. As such, it serves as a testament to the human toll of these policies. 


\section{Areas for Future Research}

The present dissertation focused on how Dominicans of Haitian descent navigate their double exclusion as racial and national others in the Dominican Republic. Doing so, it raised important questions about how mestizaje structures citizenship in the Dominican Republic and beyond. Participant observation on the contemporary situation has been the primary method of this study, leaving aside the earlier migration of cocolos and US Blacks to the island as areas for future research. In addition, this dissertation has dwelt on blackness, but Latin America, including the Dominican Republic, has been and continues to be a site of indigenous movements, as well as Asian and Middle Eastern, and more recently, Venezuelan migrations, which remain beyond the scope of this project. Moreover, our understanding of the effect of transnational funding agencies and activist networks would be enriched via a multi-sited approach. Given the targeting of Haitian in public antiimmigration campaigns around the world, researchers should continue to examine why Haitian immigrants have become the face of anti-immigrant campaigns in the Americas. Finally, 133,760 persons remain stateless in the Dominican Republic, not including the countless others whose lives were derailed by la sentencia. I end with a call to readers, and a promise to myself, to continue to support the efforts of the Dominican-Haitian grassroots movement to restore their rights as citizens and human beings. 


\section{REFERENCES}

Agamben, Giorgio. 2005. State of Exception. Chicago: University of Chicago Press.

Altuna Tezanos, Carlos Rafael. 2018. "República Dominicana, un paritorio de Haití." Listín Diario, January 11, 2018. https://www.listindiario.com/larepublica/2018/01/11/498217/republica-dominicana-un-paritorio-de-haiti.

Alvarez de Los Santos, Rafael. 2016. “¡Ya no somos indios!” Acento, April 11, 2016. http://acento.com.do/2016/opinion/8339070-ya-no-somos-indios/.

Amnesty International. 1992. Amnesty International Report, 1992. Alameda, Calif.: Hunter House Publishers.

Anderson, Benedict R. O'G. 1991. Imagined Communities: Reflections on the Origin and Spread of Nationalism. Rev. and extended ed. London: New York: Verso.

Andrews, George Reid. 2009. “Afro-Latin America: Five Questions.” Latin American and Caribbean and Ethnic Studies 4 (2): 191-210.

Aryiku, S. A., A. Salam, O. E. Dadzie, and N. G. Jablonski. 2015. "Clinical and Anthropological Perspectives on Chemical Relaxing of Afro-Textured Hair." Journal of the European Academy of Dermatology and Venereology 29 (9): 1689-95. https://doi.org/10.1111/jdv.13028.

Austerlitz, Paul. 1997. Merengue: Dominican Music and Dominican Identity. Philadelphia, Pa: Temple Univ. Press.

Badillo, Cassandra. 2001. “'Only My Hairdresser Knows for Sure': Stories of Race, Hair and Gender." NACLA Report on the Americas 34 (6): 35-37.

Bailey, Benjamin H. 2002. Language, Race, and Negotiation of Identity: A Study of Dominican Americans. The New Americans. New York: LFB Scholarly Pub. 
Baker, Lee. 2006. "Missionary Positions." In Globalization and Race: Transformations in the Cultural Production of Blackness, edited by Kamari Maxine Clarke and Deborah A. Thomas, 37-54. Durham: Duke University Press.

Banet-Weiser, Sarah. 1999. The Most Beautiful Girl in the World: Beauty Pageants and National Identity. Berkeley: University of California Press.

Banks, Ingrid. 2000. Hair Matters: Beauty, Power, and Black Women's Consciousness. New York: New York University Press.

Basch, Linda G., Nina Glick Schiller, and Cristina Szanton Blanc. 1994. Nations Unbound: Transnational Projects, Postcolonial Predicaments, and Deterritorialized Nation-States. S.1.: Gordon and Breach.

Bergad, Laird W. 2007. The Comparative Histories of Slavery in Brazil, Cuba, and the United States. New Approaches to the Americas. Cambridge: New York: Cambridge University Press.

Bernabé, Jean, Patrick Chamoiseau, Raphaël Confiant, Mohamed B. Taleb Khyar, Jean Bernabe, and Raphael Confiant. 1990. "In Praise of Creoleness." Callaloo 13 (4): 886. https://doi.org/10.2307/2931390.

Berry, Maya, Claudia Chávez Argüelles, Shanya Cordis, Sarah Ihmoud, and Elizabeth Velásquez Estrada. 2017. "Toward a Fugitive Anthropology: Gender, Race, and Violence in the Field." Cultural Anthropology 32 (4): 537-65. https://doi.org/10.14506/ca32.4.05.

Black, Paula. 2006. "Discipline and Pleasure: The Uneasy Relationship between Feminism and the Beauty Industry." In Feminism in Popular Culture, edited by Joanne Hollows and Rachel Moseley, 143-161. Oxford: New York: Berg.

Bonilla, Teófilo. 2017. “\$5 Mil Millones Gasta RD Al Año En Partos de Haitianas.” El Nacional, May 18, 2017. http://elnacional.com.do/5-mil-millones-gasta-rd-al-anoen-partos-de-haitianas/. 
Bonilla-Silva, Eduardo. 2004. "From Bi-Racial to Tri-Racial: Towards a New System of Racial Stratification in the USA.” Ethnic and Racial Studies 27 (6): 931-50. https://doi.org/10.1080/0141987042000268530.

Bordo, Susan. 1993. Unbearable Weight: Feminism, Western Culture, and the Body. Berkeley: University of California Press.

Bourdieu, Pierre. 2010[1979]. Distinction: A Social Critique of the Judgement of Taste. Routledge Classics. London: Routledge.

- 2010[1972]. Outline of a Theory of Practice. 25. printing. Cambridge Studies in Social and Cultural Anthropology 16. Cambridge: Cambridge Univ. Press.

Bourdieu, Pierre, and Loïc Wacquant. 1999. "On the Cunning of Imperialist Reason." Theory, Culture \& Society 16 (1): 41-58. https://doi.org/10.1177/026327699016001003.

Brand, Peggy Zeglin, ed. 2000. Beauty Matters. Bloomington: Indiana University Press.

Brennan, Denise. 2004. What's Love Got to Do with It? Transnational Desires and Sex Tourism in the Dominican Republic. Latin America Otherwise. Durham: Duke University Press.

Brown, Nadia. 2014. “'It's More than Hair ... That's Why You Should Care': The Politics of Appearance for Black Women State Legislators." Politics, Groups, and Identities 2 (3): 295-312. https://doi.org/10.1080/21565503.2014.925816.

Butler, Judith. 2006. Gender Trouble: Feminism and the Subversion of Identity. Routledge Classics. New York: Routledge.

Byrd, Ayana D., and Lori L. Tharps. 2014. Hair Story: Untangling the Roots of Black Hair in America. Revised edition. New York: St. Martin's Griffin.

Cabezas, Amalia L. 2009. Economies of Desire: Sex and Tourism in Cuba and the Dominican Republic. Philadelphia: Temple University Press. 
Candelario, Ginetta E. B. 2007. Black behind the Ears: Dominican Racial Identity from Museums to Beauty Shops. Durham: Duke University Press.

Carneiro, Francisco Galrão, and Sophie Sirtaine, eds. 2017. When Growth Is Not Enough: Explaining the Rigidity of Poverty in the Dominican Republic. Directions in Development Poverty. Washington, DC, USA: World Bank Group.

Carter, Donald Martin. 1997. States of Grace: Senegalese in Italy and the New European Immigration. Minneapolis: University of Minnesota Press.

Case of the Girls Yean and Bosico v. Dominican Republic. 2005. Inter-American Court of Human Rights.

Chavez, Leo R. 2017. Anchor Babies and the Challenge of Birthright Citizenship. Stanford, California: Stanford University Press.

Chetty, Raj, and Amaury Rodríguez. 2015. "Introduction: The Challenge and Promise of Dominican Black Studies.” The Black Scholar 45 (2): 1-9. https://doi.org/10.1080/00064246.2015.1012990.

Colectivo Isleño. 2015. "BOICOT AL TURISMO? ESE CAMINO NO AYUDA.” August 18, 2015.

Comaroff, John L., and Jean Comaroff. 1992. Ethnography and the Historical Imagination. Boulder: Westview Press.

Contreras, Carolina. 2014. "Derechos Humanos." Miss Rizos (blog). July 6, 2014. https://www.missrizos.com/derechos-humanos/.

Comisión Interamericana de Derechos Humanos. 2018. República Dominicana Cumplimiento Decisiones SIDH. Bogotá, Colombia. https://youtu.be/VSLk8F0M_34. 
Craig, Maxine Leeds. 2002. Ain't I a Beauty Queen? Black Women, Beauty, and the Politics of Race. New York: Oxford University Press.

Crenshaw, Kimberlé. 1991. "Mapping the Margins: Intersectionality, Identity Politics, and Violence against Women of Color." Stanford Law Review 43 (6): 1241. https://doi.org/10.2307/1229039.

Dávila, Arlene M. 2006. "The Disciplined Boundary: Anthropology, Ethnic Studies, and the 'Minority' Practitioner." Transforming Anthropology 14 (1): 35-43.

Davis, Angela Y. 1994. "Afro Images: Politics, Fashion, and Nostalgia." Critical Inquiry 21 (1): 37-45. https://doi.org/10.1086/448739.

Dawson, Imani. n.d. "Changing Beauty Standards in the Dominican Republic." A Tribe Called Curl (blog). Accessed November 5, 2014. http://ribecalledcurl.com/changing-beauty-standards-dominican-republic/.

De Genova, Nicholas. 2013. "Spectacles of Migrant 'Illegality': The Scene of Exclusion, the Obscene of Inclusion." Ethnic and Racial Studies 36 (7): 1180-98. https://doi.org/10.1080/01419870.2013.783710.

De la Fuente, Alejandro. 2001. A Nation for All: Race, Inequality, and Politics in Twentieth-Century Cuba. Chapel Hill: University of North Carolina Press.

Decena, Carlos Ulises. 2011. Tacit Subjects: Belonging and Same-Sex Desire among Dominican Immigrant Men. Durham, NC: Duke University Press.

Degler, Carl N. 1986[1971]. Neither Black nor White: Slavery and Race Relations in Brazil and the United States. Madison, WI: University of Wisconsin Press.

Deive, Carlos Esteban. 2006. Diccionario de dominicanismos. 2nd ed. Santo Domingo: Ediciones Librería la Trinitaria/Editora Manatí.

Derby, Lauren. 1994. "Haitians, Magic, and Money: Raza and Society in the HaitianDominican Borderlands, 1900 to 1937." Comparative Studies in Society and History 36 (03): 488. https://doi.org/10.1017/S0010417500019216. 
- 2003. "National Identity and the Idea of Value in the Dominican Republic." In Blacks, Coloureds and National Identity in Nineteenth-Century Latin America, edited by Nancy Priscilla Naro, 5-37. London: Institute of Latin American Studies.

. 2009. The Dictator's Seduction: Politics and the Popular Imagination in the Era of Trujillo. American Encounters/Global Interactions. Durham, NC: Duke University Press.

Diario Libre. 2007. “Afrodominicanos pugnan por su identidad,” June 13, 2007. https://www.diariolibre.com/noticias/afrodominicanos-pugnan-por-su-identidadAKDL138844.

- n.d. "La JCE, entre controversias y arduo trabajo, que incluyó el inventario." https://www.diariolibre.com/noticias/la-jce-entre-controversias-y-arduo-trabajoque-incluy-el-inventario-ANDL416152.

"Dominicans of Haitian Descent and the Compromised Right to Nationality." 2010. Open Society Foundation.

Douglas, Mary. 1996. Natural Symbols: Explorations in Cosmology. New York: Routledge.

Duany, Jorge. 1998. "Reconstructing Racial Identity: Ethnicity, Color, and Class among Dominicans in the United States and Puerto Rico." Latin American Perspectives 25 (3): 147-72. https://doi.org/10.1177/0094582X9802500308.

. 2002. The Puerto Rican Nation on the Move: Identities on the Island \& in the United States. Chapel Hill: University of North Carolina Press.

- 2008[1994]. Quisqueya on the Hudson: The Transnational Identity of Dominicans in Washington Heights. New York: Dominican Studies Institute.

Durán, Vetillo Alfau. 2013. "En torno a Duarte y a su idea de unidad de razas." CLÍO 82 (185): $25-51$.

Eller, Anne. 2016. We Dream Together: Dominican Independence, Haiti, and the Fight for Caribbean Freedom. Durham, NC: Duke University Press.

“Encuesta Nacional de Inmigrantes.” 2012. República Dominicana: Oficina Nacional de Estadística. 
Eriksen, Thomas Hylland. 2010. Ethnicity and Nationalism: Anthropological Perspectives. 3rd ed. New York: Pluto Press.

Escobar, Arturo. 1993. "Review: The Limits of Reflexivity: Politics in Anthropology's Post-'Writing Culture' Era.” Journal of Anthropological Research 49 (4): 37791.

"Facebook." n.d. Accessed September 24, 2016. https://www.facebook.com/nicky.gonzal ezmendez? $\mathrm{f}$ ref $=$ ts.

Féliz, Elaine. n.d. "Crecimiento del cabello alisado: 'El gran monstruo."” Accessed September 26, 2016. http://www.elainefeliz.com/cabello/crecimiento-del-cabelloalisado-el-gran-monstruo/.

Ferguson, James. 1992. The Dominican Republic: Beyond the Lighthouse. New York: Monthly Review Press. 2003. "Migration in the Caribbean: Haiti, the Dominican Republic and Beyond." Minority Rights Group. http://minorityrights.org/wp-content/uploads/2015/07 /MRG_Rep_Caribbean.pdf.

Flores, R., and E. Telles. 2012. "Social Stratification in Mexico: Disentangling Color, Ethnicity, and Class.” American Sociological Review 77 (3): 486-94. https://doi.org/10.1177/0003122412444720.

Foucault, Michel. 1979. The History of Sexuality. New York: Pantheon Books.

Franco, Franklin J. 2001. Ensayos profanos: Sobre racismo, pesimismo e izquierdismo. 1. ed. Santo Domingo, Rep. Dominicana: Sociedad Editorial Dominicana.

- 2003. Sobre racismo y antihaitianismo y otros ensayos. Santo Domingo: Sociedad Editorial Dominicana.

Freyre, Gilberto. 1946. The Masters and the Slaves: A Study in the Development of Brazilian Civilization. New York: Knopf. 
García Muñiz, Humberto, and Jorge L. Giovannetti. 2003. "Garveyismo y Racismo En El Caribe: El Caso de La Población Cocola En La República Dominicana.” Caribbean Studies 31 (1): 139-211.

García Peña, Lorgia. 2015. "Translating Blackness: Dominicans Negotiating Race and Belonging." The Black Scholar 45 (2): 10-20. https://doi.org/10.1080/00064246.2015.1012993. 2016. The Borders of Dominicanidad: Race, Nation, and Archives of Contradiction. Durham, NC; London: Duke University Press.

Geertz, Clifford. 1996. "Off Echoes: Some Comments on Anthropology and Law." Political and Legal Anthropology Review 19 (2): 33-37. . 1988. "Deep Hanging Out.” http://www.nybooks.com/articles/1998/10/22/deephanging-out/.

Geggus, David. 2003. "The Influence of the Haitian Revolution on the Blacks in Latin America and the Caribbean." In Blacks, Coloureds and National Identity in Nineteenth-Century Latin America, edited by Nancy Priscilla Naro, 38-59. London: Institute of Latin American Studies.

Gilroy, Paul. 1993. The Black Atlantic: Modernity and Double Consciousness. Cambrige, MA: Harvard University Press.

Glick Schiller, Nina. 1999. "Transmigrants and Nation-States: Something Old and Something New in the U.S. Immigrant Experience." In The Handbook of International Migration, edited by Charles Hirschman, Philip Kasnitz, and Josh DeWind. New York: Russell Sage Foundation.

Glick Schiller, Nina, and Ulrike Meinhof. 2011. "Singing a New Song? Transnational Migration, Methodological Nationalism and Cosmopolitan Perspectives." Music and Arts in Action 3 (3): 21-39.

Godreau, Isar P. 2015. Scripts of Blackness: Race, Cultural Nationalism, and U.S. Colonialism in Puerto Rico. Urbana: Univ. of Illinois Press. 
Golash-Boza, Tanya. 2010. "Does Whitening Happen? Distinguishing between Race and Color Levels in and African-Descended Community in Peru." Social Problems 57 (1): 138-56.

Golash-Boza, Tanya, and Pierrette Hondagneu-Sotelo. 2013. "Latino Immigrant Men and the Deportation Crisis: A Gendered Racial Removal Program." Latino Studies 11 (3): 271-92. https://doi.org/10.1057/1st.2013.14.

Goldberg, David Theo. 2002. The Racial State. Malden, Mass: Blackwell Publishers.

Gravlee, C. C. 2005. "Ethnic Classification in Southeastern Puerto Rico: The Cultural Model of 'Color.'" Social Forces 83 (3): 949-70. https://doi.org/10.1353/sof.2005.0033.

Gregory, Steven. 2007. The Devil behind the Mirror: Globalization and Politics in the Dominican Republic. Berkeley: University of California Press.

Hale, Charles R. 2006. Más Que Un Indio = More than an Indian: Racial Ambivalence and Neoliberal Multiculturalism in Guatemala. 1st ed. Santa Fe, N.M: School of American Research Press.

Hanchard, Michael George. 1994. Orpheus and Power: The "Movimento Negro" of Rio de Janeiro and Sao Paulo, Brazil 1945-1988. Princeton: Princeton University Press. http://public.eblib.com/choice/publicfullrecord.aspx?p=617272.

Harris, Marvin. 1964. Patterns of Race in the Americas. Westport, Conn: Greenwood Press.

Hasbún Martínez, Julia. 2014. "Seguridad Humana En Los Bateyes de La República Dominicana." United Nations. http://www.do.undp.org/content/dam/dominican _republic/docs/medioambiente/publicaciones/pnud_do_reporte $\% 20$ bateyes $\% 20 \mathrm{w}$ eb.pdf. 
Hernández, Tanya Katerí. 2015. "Colorism and the Law in Latin America - Global Perspectives on Colorism Conference Remarks." Washington University Global Studies Law Review 14 (4): 683-93.

- 2013. Racial Subordination in Latin America: The Role of the State, Customary Law, and the New Civil Rights Response. Cambridge ; New York: Cambridge University Press.

Hill Collins, Patricia. 2009. Black Feminist Thought: Knowledge, Consciousness, and the Politics of Empowerment. 2nd ed. New York: Routledge.

Hintzen, Amelia. 2016. Cultivating Resistance: Haitian-Dominican Communities and the Dominican Sugar Industry, 1915-1990. PhD Diss. Coral Gables: University of Miami.

Hoetink, Harry. 1962. “Americans' in Samaná.” Caribbean Studies 2 (1): 3-22. - 1971. Caribbean Race Relations: A Study of Two Variants. Translated by Eva M. Hooykas. London: Oxford University Press.

Hoffnung-Garskof, Jesse. 2008. A Tale of Two Cities: Santo Domingo and New York after 1950. Princeton: Princeton University Press.

Hooker, Juliet. 2005. "Indigenous Inclusion/Black Exclusion: Race, Ethnicity and Multicultural Citizenship in Latin America." Journal of Latin American Studies 37 (2): 285-310. https://doi.org/10.1017/S0022216X05009016.

hooks, bell. 1993. A Woman's Mourning Song. New York: Harlem River Press.

Horst, Oscar H., and Katsuhiro Asagiri. 2010. "The Odyssey of Japanese Colonists in the Dominican Republic.” Geographical Review 90 (3): 335-38. https://doi.org/10.1111/j.1931-0846.2000.tb00341.x.

Howard, David John. 2001. Coloring the Nation: Race and Ethnicity in the Dominican Republic. Boulder, CO: L. Rienner Publishers. 
“'Illegal People': Haitians and Dominico-Haitians in the Dominican Republic." 2002. Human Rights Watch. https://www.hrw.org/reports/2002/domrep/domrep 0402.pdf.

Inter-American Commission on Human Rights. 2015. "Report on the Situation of Human Rights in the Dominican Republic." Organization of American States. http://www.oas.org/en/iachr/reports/pdfs/DominicanRepublic-2015.pdf.

"Informe Anual." 1991. Comisión Interamericana de Derechos Humanos. https://www.cidh.oas.org/annualrep/91span/cap.V.htm.

Itzigsohn, José. 2009. Encountering American Faultines: Race, Class, and the Dominican Experience in Providence. New York: Russell Sage Foundation.

Itzigsohn, José, Carlos Dore Cabral, Esther Hernández Medina, and Obed Vazquez. 1999. "Mapping Dominican Transnationalism: Narrow and Broad Transnational Practices." Ethnic and Racial Studies 22 (2): 316-39. https://doi.org/10.1080/014198799329503.

Itzigsohn, José, and Carlos Dore-Cabral. 2000. "Competing Identities? Race, Ethnicity and Panethnicity Among Dominicans in the United States." Sociological Forum 15 (2): $225-47$.

Joseph, Daniel. 2015. "Informe de Auditoría Al Registro Civil Desde 1929 Al 2007." Junta Central Electioral. Noticias (blog). May 26, 2015. http://jce.gob.do/Noticias/informe-auditoria-registro-civil-1929-2007-tc0168-13ley169-14.

Krogstad, Jens, Jeffrey S. Passel, and D'Vera Cohn. 2017. "5 Facts about Illegal Immigration in the U.S." Pew Research Center. http://www.pewresearch.org/fact$\operatorname{tank} / 2017 / 04 / 27 / 5$-facts-about-illegal-immigration-in-the-u-s/\#.

"La variable étnico racial en los censos de población en aa República Dominicana." 2012. Oficina Nacional de Estadística. https://www.one.gob.do/Multimedia/Download?ObjId=1938. 
León, Viviano de. 2011. "Reforma a ley electoral eliminaría el color indio." Listín Diario, November 11, 2011. http://www.listindiario.com/larepublica/2011/11/11/210557/rd-sera-de-negros-blancos-y-mulatos.

Levitt, Peggy. 2001. The Transnational Villagers. Berkeley: University of California Press.

Levitt, Peggy, and Nina Glick Schiller. 2004. "Conceptualizing Simultaneity: A Transnational Social Field Perspective on Society." International Migration Review 38 (145): 595-629.

Ley General de Migración. 2004. Vol. 285-04. https://presidencia.gob.do/themes/custom/presidency/docs/gobplan/gobplan15/Ley-No-285-04-Migracion.pdf.

Li, Tania Murray. 2007. "Governmentality.” Anthropologica 49 (2).

Listín Diario. 2011. “De 'Indio' a 'Mulato,” November 11, 2011, sec. Editorial. http://www.listindiario.com/editorial/2011/11/11/210567/de-indio-a-mulato.

López, Gerald. 2015. "Moreno, Negro, Indio: Explained." La Galeria Magazine (blog). May 29, 2015. http://www.lagaleriamag.com/morenonegroindio/.

López, Nancy. 2013. "Killing Two Birds with One Stone? Why We Need Two Separate Questions on Race and Ethnicity in the 2020 Census and Beyond." Latino Studies 11 (3): 428-38. https://doi.org/10.1057/lst.2013.25.

"Los mejores memes del caso Nicky González vs. Ligia Amada Melo." n.d. Metrord Accessed September 21, 2016. http://www.metrord.do/noticias/los-mejoresmemes-del-caso-nicky-gonzalez-vs-ligia-amada-melo/ftwpgA--yRx0Bwk4Ah6A/.

Lovell, P. A., and C. H. Wood. 1998. "Skin Color, Racial Identity, and Life Chances in Brazil." Latin American Perspectives 25 (3): 90-109. https://doi.org/10.1177/0094582X9802500305. 
Loveman, Mara. 2014. National Colors: Racial Classification and the State in Latin America. Oxford: Oxford University Press.

Lugo, Gizelle. 2013. “The Dominican Republic's Epidemic of Domestic Violence.” The Guardian, 2013.

Luibhéid, Eithne. 2013. Pregnant on Arrival: Making the Illegal Immigrant. Minneapolis: University of Minnesota Press.

Luna, Katheryrn, Ricardo Santana, Benny Rodriguez, and Florentino Durán. 2017. "Caso parturientas de Haití preocupa a todas las regiones." Listín Diario, August 25, 2017. https://www.listindiario.com/la-republica/2017/08/25/479711/casoparturientas-de-haiti-preocupa-a-todas-las-regiones.

Martínez, Leonardo. 2006. "Análisis sociodemográfico de la base poblacional batey." COPRESIDA. http://copresida.gob.do/bateyes/recursos/analisis_sociodemogr afico_Batey.pdf.

Martínez, Samuel. 1995. Peripheral Migrants: Haitians and Dominican Republic Sugar Plantations. 1st ed. Knoxville: University of Tennessee Press.

_. 2003. "Not a Cockfight: Rethinking Haitian-Dominican Relations." Latin American Perspectives 30 (3): 80-101. https://doi.org/10.1177/0094582X03030003006.

Martínez, Samuel, and Bridget Wooding. 2017. "El antihaitianismo en la República Dominicana: ¿un giro biopolítico?” Migración y Desarrollo 15 (28): 95-123.

Martínez-Echazábal, Lourdes. 1998. "Mestizaje and the Discourse of National/Cultural Identity in Latin America, 1845-1959." Latin American Perspectives 25 (3): 2142 .

Martínez-Vergne, Teresita. 2005. Nation \& Citizen in the Dominican Republic, 18801916. Chapel Hill: University of North Carolina Press. 
Mayes, A., Y. C. Martin, C. U. Decena, K. Jayaram, and Y. Alexis. 2013. "Transnational Hispaniola: Toward New Paradigms in Haitian and Dominican Studies." Radical History Review 2013 (115): 26-32. https://doi.org/10.1215/01636545-1724697.

Mayes, April J. 2014. The Mulatto Republic: Class, Race, and Dominican National Identity. Gainesville: University Press of Florida.

Mercer, Kobena. 1987. "Black Hair/Style Politics." New Formations, no. 3: 33-54.

—. 2013. Welcome to the Jungle: New Positions in Black Cultural Studies. Hoboken: Taylor and Francis.

http://www.123library.org/book_details/?id=109570.

"Migration Profiles - Commons Set of Indicators." 2014. United Nations, DESAPopulation Division and UNICEF. https://esa.un.org/miggmgprofiles/indic ators/files/DominicanRepublic.pdf.

Miller, Marilyn Grace. 2004. Rise and Fall of the Cosmic Race: The Cult of Mestizaje in Latin America. Austin: University of Texas Press.

Moreno, Pilar. 2007. "Sonia Pierre defiende nacionalidad y recibe manifestaciones de apoyo." Listín Diario, March 31, 2007. https://www.listindiario.com/larepublica/2007/03/31/8058/sonia-pierre-defiende-nacionalidad-y-recibemanifestaciones-de-apoyo.

Morrisson, Angela. 2006. "Black Skin, Big Hair: The Cultural Appropriation of the Afro." In Image into Identity: Constructing and Assigning Identity in a Culture of Modernity, edited by Michael J. Wintle, 101-16. Studia Imagologica 11. Amsterdam: Rodopi.

Moya Pons, Frank. 1981. "Dominican National Identity and Return Migration." In Selected Papers from the Conference Celebrating the 50th Anniversary of the Center, 23-33. Gainesville, FL: Center for Latin American Studies. . 1998. The Dominican Republic: A National History. Princeton, N.J: Markus Wiener Publishers. . ed. 2010. Historia de La República Dominicana. Historia de Las Antillas 2. Madrid: Consejo Superior de Investigaciones Científicas. 
Murray, Gerald F., and Marina Ortiz. 2012. Pelo bueno/pelo malo: Estudio antropológico de los salones de belleza en la República Dominicana. Santo Domingo: Fondo Para el Financiamiento de la Microempresa, Inc.

Nicholls, David. 1996. From Dessalines to Duvalier: Race, Colour, and National Independence in Haiti. Rev. ed. New Brunswick, N.J: Rutgers University Press.

Nichter, Mark, and Mimi Nichter. 1991. "Hype and Weight." Medical Anthropology 13 (3): 249-84.

Omi, Michael, and Howard Winant. 2015. Racial Formation in the United States. Third ed. New York: Routledge.

Ong, Aihwa. 1999. "Cultural Citizenship as Subject Making: Immigrants Negotiate Racial and Cultural Boundaries in the United States." In Race, Identity, and Citizenship: A Reader, edited by Rodolfo D. Torres, Luis F. Mirón, and Jonathan Xavier Inda. Malden, Mass: Blackwell Publishers.

Padilla, Mark. 2007. Caribbean Pleasure Industry: Tourism, Sexuality, and AIDS in the Dominican Republic. Chicago: The University of Chicago Press.

Paulino, Edward. 2016. Dividing Hispaniola: The Dominican Republic's Border Campaign against Haiti, 1930-1961. Pittsburgh: University of Pittsburgh Press.

Paulino, Edward, and Scherezade García. n.d. "Bearing Witness to Genocide: The 1937 Haitian Massacre and Border of Lights." Afro-Hispanic Review 32 (2): 111-18.

Pedro Francisco Bonó. 2007. Santo Domingo, República Dominicana: Archivo General de la Nación. http://website.agn.gov.do:8080/publicaciones/coleccionjuvenil/textos-selectos-pedro-francisco-bono.

Peralta, Eyder. 2015. "3 Things You Should Know About Birthright Citizenship." National Public Radio. The Two-Way (blog). August 18, 2015. https://www.npr.org/sections/thetwo-way/2015/08/18/432707866/3-things-youshould-know-about-birthright-citizenship. 
Pérez, Gina M. 2015. Citizen, Student, Soldier: Latina/o Youth, JROTC, and the American Dream. New York: New York University Press.

Pérez, Melvyn. 2015. Dominican-Haitian Crisis, Beyond the Surface-Junot Diaz, Edwidge Danticat, Edilberto Román. https://www.youtube.com/watch?v=E1zum

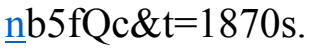

Perry, Marc D. 2016. Negro Soy Yo: Hip Hop and Raced Citizenship in Neoliberal Cuba. Refiguring American Music. Durham, NC: Duke University Press.

Petrozziello, Allison J. 2012. "Los trabajadores de la construcción haitianos en la República Dominicana: Un estudio exploratorio de los indicadores de trabajo forzoso." OBMICA. https://www.dol.gov/ilab/reports/pdf/2012\%20DRHaiti\%20Construction\%20Report-\%20SPANISH\%20TRANSLATION.pdf.

Petrozziello, Allison J., Amelia Hintzen, and Juan Carlos González Díaz. 2014. "Género y el riesgo de apatridia para la población de ascendencia haitiana en los bateyes de la República Dominicana.” Santo Domingo, República Dominicana: OBMICA.

Planas, Roque. 2015. "No Foreign Country Can Change Dominican Republic's Immigration Laws, President Says." Huffington Post, February 27, 2015. https://www.huffingtonpost.com/2015/02/27/danilo-medinadeportations_n_6772602.html.

Rahier, Jean Muteba. 1998. "Blackness, the Racial/Spatial Order, Migrations, and Miss Ecuador 1995-96." American Anthropologist 100 (2): 421-30. https://doi.org/10.1525/aa.1998.100.2.421. . 2008. "Soccer and the (Tri-) Color of the Ecuadorian Nation: Visual and Ideological (Dis-) Continuities of Black Otherness from Monocultural Mestizaje to Multiculturalism." Visual Anthropology Review 24 (2): 148-82. https://doi.org/10.1111/j.1548-7458.2008.00011.x.

— ed. 2012. Black Social Movements in Latin America: From Monocultural Mestizaje to Multiculturalism. New York: Palgrave Macmillan.

Ramírez, Dixa. 2018. Colonial Phantoms: Belonging and Refusal in the Dominican Americas, from the 19th Century to the Present. New York: New York University Press. 
Ramos-Zayas, Ana Y. 2012. Street Therapists: Race, Affect, and Neoliberal Personhood in Latino Newark. Chicago: The University of Chicago Press.

Reischer, Erica, and Kathryn S. Koo. 2004. "The Body Beautiful: Symbolism and Agency in the Social World." Annual Review of Anthropology 33 (1): 297-317. https://doi.org/10.1146/annurev.anthro.33.070203.143754.

Ricourt, Milagros. 2016. The Dominican Racial Imaginary: Surveying the Landscape of Race and Nation in Hispaniola. Critical Caribbean Studies. New Brunswick, NJ: Rutgers University Press.

Rivera, Pedro R. 2015. "The Making of a Mulatto Community: Santo Domingo and the 'Colour Wave.'” Caribbean Quarterly 61 (4): 100-115.

Riveros, Natalia. 2014. Estado de la cuestión de la población de los bateyes dominicanos en relación a la documentación. Santo Domingo: Observatorio Migrantes del Caribe.

Roberts, Dorothy. 1997. Killing the Black Body: Race, Reproduction, and the Meaning of Liberty. New York, N.Y: Pantheon Books.

Robles, Frances. 2015. "Immigration Rules in Bahamas Sweep Up Haitians.” New York Times, January 30, 2015. https:/www.nytimes.com/2015/01/31/world/haitiansare-swept-up-as-bahamas-tightens-immigration-rules.html.

Rodríguez G., Virginia. 2007. “El fin del desrizado.” Listín Diario, July 15, 2007. https://www.listindiario.com/ld-lecturas-de-domingo/2007/7/15/20741/El-fin-deldesrizado.

Rodríguez-Silva, Ileana M. 2012. Silencing Race: Disentangling Blackness, Colonialism, and National Identities in Puerto Rico. New York: Palgrave Macmillan. 
Roorda, Eric. 1998. The Dictator Next Door: The Good Neighbor Policy and the Trujillo Regime in the Dominican Republic, 1930-1945. Durham, NC: Duke University Press.

Rosaldo, Renato. 1994. "Cultural Citizenship and Educational Democracy." Cultural Anthropology 9 (3): 402-11. https://doi.org/10.1525/can.1994.9.3.02a00110.

Rosario, Reina, and Jorge Hung Ulloa. 2006. "Algunos aspectos socioculturales de la inmigración haitiana hacia la República Dominicana." Ciencia y Sociedad 31 (1): $64-124$.

Roth, Wendy D. 2012. Race Migrations: Latinos and the Cultural Transformation of Race. Stanford, California: Stanford University Press. . 2013. "A Single Shade of 'Negro': Henry Louis Gates' Depictions of Blackness in the Dominican Republic." Latin American and Caribbean Ethnic Studies 8 (1): 92-96. https://doi.org/10.1080/17442222.2013.768465.

Sá Dias, Tania Cristina de, André Rolim Baby, Telma Mary Kaneko, and Maria Valéria Robles Velasco. 2007. "Relaxing/Straightening of Afro-Ethnic Hair: Historical Overview." Journal of Cosmetic Dermatology 6 (1): 2-5. https://doi.org/10.1111/j.1473-2165.2007.00294.x.

Safa, Helen. 1998. “Introduction.” Latin American Perspectives 25 (3): 3-20.

Sagás, Ernesto. 2000. Race and Politics in the Dominican Republic. Gainesville: University Press of Florida.

Sagás, Ernesto, and Orlando Inoa. 2003. The Dominican People: A Documentary History. Princeton, N.J: Wiener.

Sagás, Ernesto, and Sintia Molina, eds. 2004. Dominican Migration: Transnational Perspectives. New World Diaspora Series. Gainesville: University Press of Florida.

Santana, Ricardo. 2018. "Un total de 99\% partos fueron de extranjeras en Santiago en 2017." Listín Diario, January 6, 2018. https://www.listindiario.com/larepublica/2018/01/06/497610/un-total-de-99-partos-fueron-de-extranjeras-ensantiago-en-2017. 
Saunders, Katie. 2013. "Good Hair, Bad Hair, Dominican Hair, Haitian Hair.” Illinois State University. http://ir.library.illinoisstate.edu/cgi/viewcontent.cgi?articl $\mathrm{e}=1014 \&$ context $=$ mts.

Sawyer, Mark Q., and Tianna S. Paschel. 2007. "We Didn't Cross the Color Line, The Color Line Crossed US."' Du Bois Review: Social Science Research on Race 4 (02). https://doi.org/10.1017/S1742058X07070178.

Scott, James C. 1990. Domination and the Arts of Resistance: Hidden Transcripts. New Haven: Yale University Press. . 2000. Weapons of the Weak: Everyday Forms of Peasant Resistance. New Haven: Yale Univ. Press.

Secretaría de Estado de lo Interior y Policía. 1975. Primer censo nacional de República Dominicana, 1920. Santo Domingo: Editora de la Universidad Autónoma de Santo Domingo.

Ser Humano TV. n.d. Ser Humano hay discriminación racial En RD? Yaritza Reyes, Carolina Contreras, Brenda Franco. https://www.youtube.com/watch?v=HJbqBrwNcw.

Sidanius, Jim, Yesilernis Pena, and Mark Sawyer. 2001. "Inclusionary Discrimination: Pigmentocracy and Patriotism in the Dominican Republic." Political Psychology 22 (4): 827-51. https://doi.org/10.1111/0162-895X.00264.

Silié Valdéz, Rubén. 1998. “Aspectos socio-históricos sobre la inmigración haitiana a la República Dominicana.” In La República Dominicana y Haití frente al futuro, edited by Rubén Silié Valdéz, Orlando. Inoa, and Arnold Antonin, 2-31. Santo Domingo, R.D: FLACSO.

Simmons, Kimberly Eison. 2009. Reconstructing Racial Identity and the African Past in the Dominican Republic. New World Diasporas. Gainesville, FL: University Press of Florida. 
“'Sin papeles no soy nadie': Personas Apátridas En La República Dominicana.” 2015. Amnesty International. http://www.refworld.org/cgibin/texis/vtx/rwmain/opendocpdf.pdf?reldoc=y\&docid=5652e09f4.

Siu, Lok C.D. 2001. "Diasporic Cultural Citizenship: Chineseness and Belonging in Central America." Social Text 69 (19): 7-28. Duke University Press: Durham.

Skidmore, Thomas E. 1993. Black into White: Race and Nationality in Brazilian Thought. Durham, NC: Duke University Press.

Sørensen, Ninna Nyberg. 1996. “'Nueva York es tan sólo otra capital dominicanaMadrid es otro mundo': Prácticas espaciales y culturales de desplazamiento entre migrantes dominicanos en Nueva York y Madrid." Género y Sociedad 4 (1): 160220.

Spivak, Gayatri Chakravorty. 1988. Can the Subaltern Speak? Basingstoke: Macmillan.

Stepan, Nancy. 1991. The Hour of Eugenics: Race, Gender, and Nation in Latin America. Ithaca: Cornell University Press.

Stutzman, Ronald. 1981. "El Mestizaje: An All-Inclusive Ideology of Exclusion.” In Cultural Transformations and Ethnicity in Modern Ecuador, edited by Norman E. Whitten, 45-94. Urbana: University of Illinois Press.

Suero, Indhira. 2011. "La Cuestión Mulata.” Listín Diario, December 3, 2011.

https://www.listindiario.com/ventana/2011/12/2/213223/La-cuestion-mulata.

Tannenbaum, Frank. 1992. Slave and Citizen. Boston: Beacon Press.

Tate, Shirley. 2007. "Black Beauty: Shade, Hair and Anti-Racist Aesthetics." Ethnic and Racial Studies 30 (2): 300-319. https://doi.org/10.1080/01419870601143992. . 2009. Black Beauty: Aesthetics, Stylization, Politics. Farnham, Surrey, England ; Burlington, VT: Ashgate. 
Tavernier, LaToya A. 2008. "The Stigma of Blackness: Anti-Haitianism in the Dominican Republic." Socialism and Democracy 22 (3): 96-104. https://doi.org/10.1080/08854300802361554.

Taylor, Jacqueline Sánchez. 2001. "Dollars Are a Girl's Best Friend? Female Tourists' Sexual Behaviour in the Caribbean." Sociology 35 (3): 749-64.

Telles, Edward. 2012. "The Overlapping Concepts of Race and Colour in Latin America." Ethnic and Racial Studies 35 (7): 1163-68. https://doi.org/10.1080/01419870.2012.657209.

Telles, Edward Eric. 2006. Race in Another America: The Significance of Skin Color in Brazil. Princeton, NJ: Princeton University Press.

Telles, Edward, and Tianna Paschel. 2014. "Who Is Black, White, or Mixed Race? How Skin Color, Status, and Nation Shape Racial Classification in Latin America." American Journal of Sociology 120 (3): 864-907. https://doi.org/10.1086/679252.

Thomas, Deborah A. 2004. Modern Blackness: Nationalism, Globalization, and the Politics of Culture in Jamaica. Latin America Otherwise. Durham: Duke University Press.

Torres-Saillant, Silvio. 1998. The Dominican Americans. The New Americans. Westport, Conn: Greenwood Press. . 2000. "The Tribulations of Blackness: Stages in Dominican Racial Identity." Callaloo 23 (3): 1086-1111. https://doi.org/10.1353/cal.2000.0173.

- 2010. Introduction to Dominican Blackness. 2nd ed. New York: Dominican Studies Institute.

“Tu afro no cabe en la foto.” 2014. El País. Accessed September 28, 2016. http://elpais.com/elpais/2014/07/28/eps/1406564419_461753.html.

Turits, R. L. 2002. “A World Destroyed, A Nation Imposed: The 1937 Haitian Massacre in the Dominican Republic." Hispanic American Historical Review 82 (3): 589636. https://doi.org/10.1215/00182168-82-3-589. 
Turits, Richard Lee. 2003. Foundations of Despotism: Peasants, the Trujillo Regime, and Modernity in Dominican History. Stanford, CA: Stanford Univ. Press.

Twine, France Winddance. 1998. Racism in a Racial Democracy: The Maintenance of White Supremacy in Brazil. New Brunswick, NJ: Rutgers University Press.

Vasconcelos, José. 1997. The Cosmic Race: A Bilingual Edition. Translated by Didier Tisdel Jaén. Baltimore, MD: Johns Hopkins University Press.

Vega, Bernardo. 1988. Trujillo y Haití. Santo Domingo: Fundación Cultural Dominicana.

Wade, Peter. 1993. Blackness and Race Mixture: The Dynamics of Racial Identity in Colombia. Baltimore: Johns Hopkins University Press.

- 1997. Race and Ethnicity in Latin America. Chicago, IL: Pluto Press.

—. 2002. "Introduction: The Colombian Pacific in Perspective." The Journal of Latin American and Caribbean Anthropology 7 (2): 2-33.

- 2003. "Race and the Nation in Latin America: An Anthropological View." In Race and Nation in Modern Latin America, edited by Nancy Appelbaum, Anne Macpherson, and Karin Rosemblatt, 263. Chapel Hill, NC: University of North Carolina Press.

— 2005, "Rethinking Mestizaje: Ideology and Lived Experience." Journal of Latin American Studies, Volume 37: 239-257.

_. 2009. Race and Sex in Latin America. New York: Pluto Press.

Wagley, Charles. 1965. "On the Concept of Social Race in the Americas." In Contemporary Cultures and Societies in Latin America, edited by Dwight B. Heath, 531-45. New York: Random House.

Walker, S. 2000. "Black Is Profitable: The Commodification of the Afro, 1960-1975." Enterprise and Society 1 (3): 536-64. https://doi.org/10.1093/es/1.3.536.

Weekes, Debbie. 1997. "Shades of Blackness: Young Black Female Constructions of Beauty." In Black British Feminism: A Reader, edited by Heidi Safia Mirza, 11326. New York: Routledge. 
Weitz, Rose. 2001. "Women and their Hair: Seeking Power through Resistance and Accommodation." Gender \& Society 15 (5): 667-86. https://doi.org/10.1177/089124301015005003.

Wheeler, Eva Michelle. 2015. "Race, Legacy, and Lineage in the Dominican Republic: Shifting Paradigms." The Black Scholar 45 (2): 34-44. https://doi.org/10.1080/00064246.2015.1012997.

Whitten, Norman E. 1974. Black Frontiersmen: A South American Case. Cambridge, Mass.: Schenkman Pub. Co.

Whitten, Norman E., and Arlene Torres, eds. 1998. Blackness in Latin America and the Caribbean: Social Dynamics and Cultural Transformations. vols. 1 and 2 vols. Blacks in the Diaspora. Bloomington: Indiana University Press.

Wolf, Naomi. 1991. The Beauty Myth: How Images Are Used against Women. Great Britain: Vintage Books.

Wooding, Bridget. 2009. "Contesting Discrimination and Statelessness in the Dominican Republic." Forced Migration Review 32: 23-25.

Wooding, Bridget, and Richard David Moseley-Williams. 2004. Needed but Unwanted: Haitian Immigrants and Their Descendants in the Dominican Republic. Santo Domingo: Catholic Institute for International Relations.

Wucker, Michele. 1999. Why the Cocks Fight: Dominicans, Haitians, and the Struggle for Hispaniola. New York: Hill and Wang. 
VITA

\section{JACQUELINE LYON}

$2011-2018$

Ph.D. Sociocultural Anthropology, ABD

Global and Sociocultural Studies Program

Florida International University

$2005-2011$

B.A. Political Science and Latin American and Latino/a

Studies, 2010

DePaul University

Cum Laude

\section{PUBLICATIONS AND PRESENTATIONS}

2017 Hegemonic Blackness: Translating Racial Justice in Dominican Diasporas. Latin American Studies Association Conference. Lima, Peru. May.

2017 Invited Lecture. "Muertos Civiles: Race, Statelessness, and Afro-Diasporic Activism in the Dominican Republic." Bates College. Lewiston, ME. Jan.

2016 “Por Debajo del Pie: Dominican-Haitian Racial Activism.” American Anthropological Association, Minneapolis, MN. Nov.

2016 “Inheriting Illegality: Race Dominico-Haitian Activism.” Caribbean Studies Association Conference, Port-au-Prince, Haiti. June.

2015 "Inheriting Illegality: Race and Haitian Migration to the Dominican Republic." Migration Without Boundaries Conference, Michigan State University. October.

2015 “'Yo Amo Mi Pajon': Embodied Representations of Race in the Dominican Republic's Natural Hair Movement. Cuban Research Institute Conference. Florida International University. Feb.

2014 Organizer and Presenter "Creating and Consuming: Media, Citizenship, and Latinidad.”Latin@ Studies Conference. Chicago, IL. July.

2013 Lyon, Jacqueline. 2013, "Book Review: Latina Teens, migration and popular culture by Lucila Vargas" Latino Studies Journal vol. 11(3) pp. 445-446. 